Claudia Zavaloni Melotti

\title{
Pesquisa do rearranjo dos genes das cadeias leve e pesada de imunoglobulina nos processos linfoproliferativos cutâneos de células B
}

Tese apresentada à Faculdade de Medicina da Universidade de São Paulo para obtenção do título de Doutor em Ciências.

Área de concentração: Dermatologia

Orientador: Prof. Dr. José Antonio Sanches Junior

São Paulo

2007 


\section{Dados Internacionais de Catalogação na Publicação (CIP)}

Preparada pela Biblioteca da

Faculdade de Medicina da Universidade de São Paulo

Creprodução autorizada pelo autor

Melotti, Claudia Zavaloni

Pesquisa do rearranjo dos genes das cadeias leve e pesada de imunoglobulina nos processos linfoproliferativos cutâneos de células B / Claudia Zavaloni Melotti. -- São Paulo, 2007.

Tese(doutorado)--Faculdade de Medicina da Universidade de São Paulo. Departamento de Dermatologia.

Área de concentração: Dermatologia.

Orientador: José Antonio Sanches Junior.

Descritores: 1.Linfoma/diagnóstico 2.Linfócitos B 3.Pseudolinfoma 4.Cadeias leves de imunoglobulina 5.Cadeias pesadas de imunoglobulina 6 . Reação em cadeia da polimerase 7.Pele

USP/FM/SBD-294/07 
Aos meus pais, Laércio e Clélia, pelo exemplo de vida, constante estímulo ao aprender, amor e sabedoria, apoiando meus passos.

Ao Querido Emilio, pelo amor, presença, apoio e estímulo nas principais etapas da construção deste projeto.

Aos meus irmãos, Laércio, Rogério, Marcelo e André, pelo amor incondicional. 
AGRADECIMENTOS 
Ao Dr. Jose Antonio Sanches Jr., meu orientador, pelo apoio, confiança, estimulo constante e exemplo profissional, ético e humano.

À médica patologista e amiga, Dra. Maria Fernanda C. Amary, pelo suporte e toda a ajuda, sem a qual esse projeto não teria o formato atual.

Ao Dr. Timoty C. Diss e a University College London, por todo conhecimento e ensinamento em biologia molecular.

Ao Prof. Dr. Evandro A. Rivitti, novamente, pela inspiração para a minha querida carreira dermatológica e oportunidades.

À médica patologista, Dra. Mirian N. Sotto pela contribuição e orientação desde a primeira etapa deste projeto.

Aos funcionários do Laboratório de Anatomia-patológica do Departamento de Dermatologia, em especial a Maria Cristina Galharda, pelo auxílio técnico.

Aos colegas do Ambulatório de Oncologia Cutânea do Departamento de Dermatologia do HCFMUSP, pelo apoio constante.

À Dra Celina Gil Ponte, colega e amiga, pelo apoio e compreensão.

Ao Dr. Cyro Festa Neto, pelo incentivo, atenção e bom humor durante todo o processo da pós-graduação.

À Sra Eli Maria, pelo auxílio durante todo o processo da pós-graduação.

À pós-graduação da Universidade de São Paulo pela oportunidade e a Coordenação de Aperfeiçoamento de Pessoal de Nível Superior (CAPES) pelo suporte financeiro. 
Esta tese está de acordo com as seguintes normas, em vigor no momento desta publicação:

Referências: adaptado de International Committee of Medical Journals Editors (Vancouver)

Universidade de São Paulo. Faculdade de Medicina. Serviço de Biblioteca e Documentação. Guia de apresentação de dissertações, teses e monografias. Elaborado por Anneliese Carneiro da Cunha, Maria Julia de A. L. Freddi, Maria F. Crestana, Marinalva de Souza Aragão, Suely Campos Cardoso, Valeria Vilhena. $2^{\mathrm{a}}$ ed São Paulo: Serviço de Biblioteca e Documentação; 2005.

Abreviaturas dos títulos dos periódicos de acordo com List of Journals Indexed in Index Medicus 
SUMÁRIO 


\section{SUMÁRIO}

LISTA DE ABREVIATURAS, SIGLAS E SÍMBOLOS

RESUMO

SUMMARY

1. INTRODUÇÃO

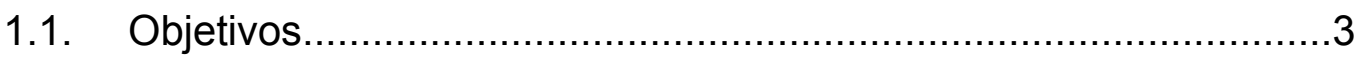

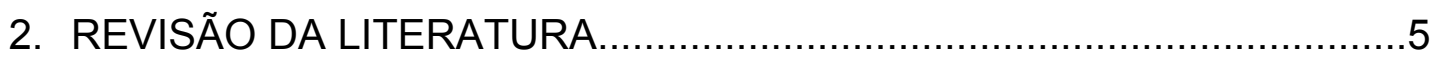

2.1. Processos linfoproliferativos cutâneos de células $B$........................6

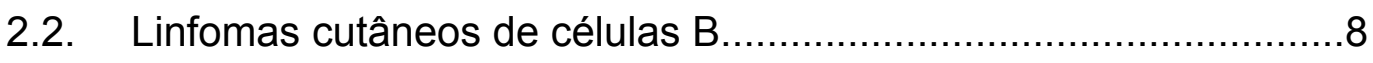

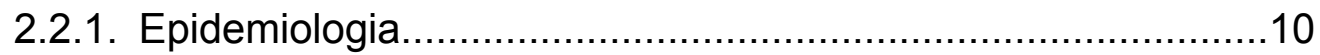

2.2.2. Classificação dos linfomas cutâneos.....................................10

2.2.3. Aspectos clínicos e prognóstico...........................................12

2.2.4. Aspectos histológicos e imunoistoquímicos ...........................14

2.3. Pseudolinfomas cutâneos......................................................19

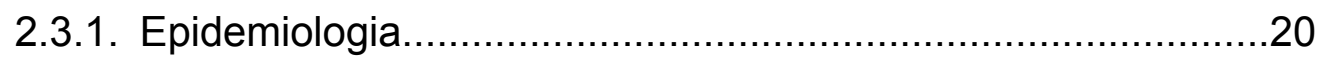

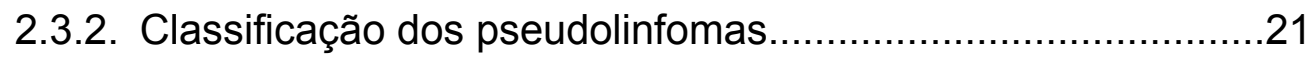

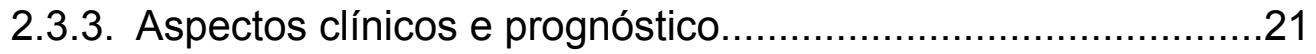

2.3.4. Aspectos histológicos e imunoistoquímicos ............................23

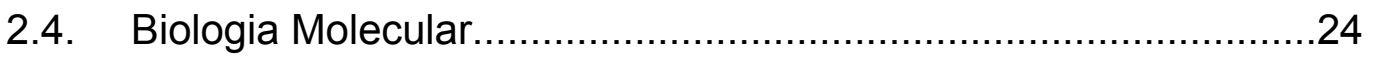

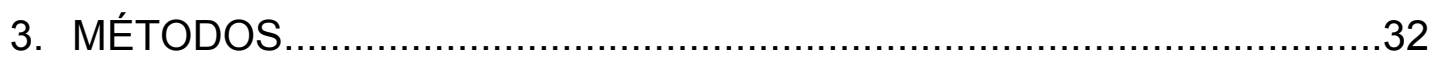

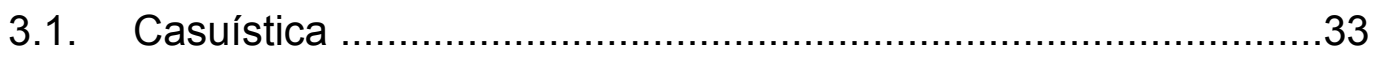

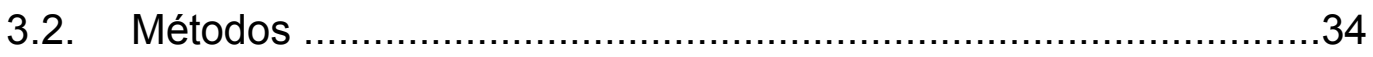

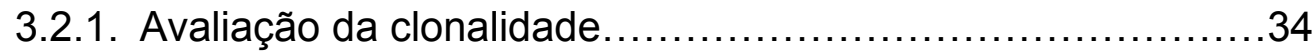

3.2.1.1. Extração do DNA através do método crude lysate.......34

3.2.1.2. Ampliação do DNA por PCR ........................................

3.2.1.3. Corrida eletroforética e revelação da imagem...............40 


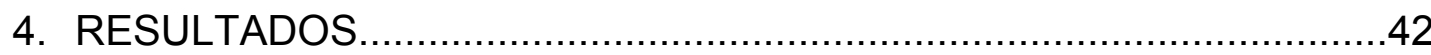

4.1. Controle da presença e da qualidade do DNA da casuística........43

4.2. Pesquisa do rearranjo dos genes da cadeia pesada de $\lg . . . . . . . .44$

4.3. Pesquisa do rearranjo dos genes da cadeia leve de $\lg . . . \ldots \ldots \ldots \ldots . . . . .47$

4.4. Pesquisa do rearranjo dos genes do receptor de células T.........49

4.5. Contribuição do estudo da clonalidade na definição diagnóstica

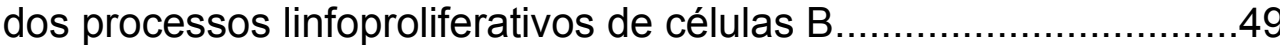

4.6. Detecção da monoclonalidade nos LCCB conforme classificação da WHO-EORTC..................................................................... 50

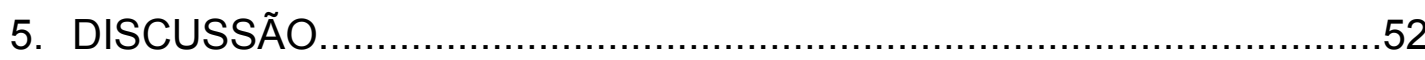

5.1. Aspectos da biologia molecular...........................................56

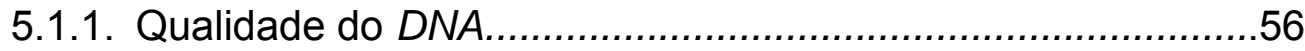

5.1.2. Interpretação dos resultados.............................................58

5.1.3. Escolha correta dos primers e protocolos...........................59

5.1.4. Pesquisa da clonalidade do rearranjo dos genes da cadeia

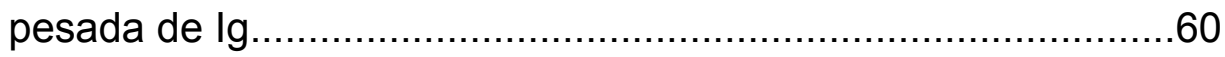

5.1.5. Pesquisa da clonalidade do rearranjo dos genes da cadeia leve de $\lg$. 61

5.2. Pesquisa da clonalidade nos linfomas segundo a classificação da

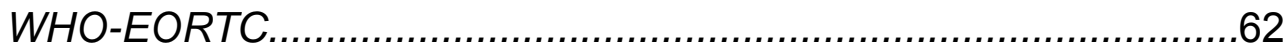

5.3. Perspectivas futuras.......................................................63

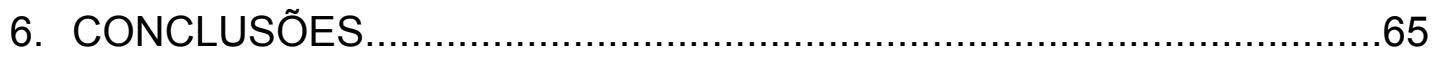

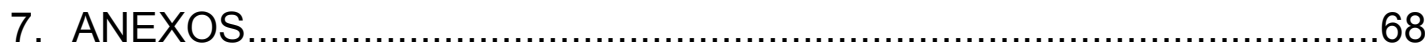

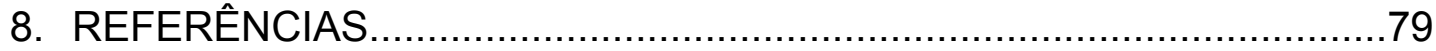




\section{LISTA DE ABREVIATURAS, SIGLAS E SÍMBOLOS}

$\begin{array}{ll}\text { WHO } & \text { Organização Mundial de Saúde } \\ \text { EORTC } & \text { Organização Européia de Pesquisa e Tratamento do } \\ & \text { Câncer } \\ \text { NK } & \text { Natural-killer } \\ \text { LCCB } & \text { linfomas cutâneos de células B } \\ \text { LCCT/NK } & \text { linfomas cutâneos de células T /NK } \\ \text { PLCB } & \text { pseudolinfomas cutâneos de células B } \\ \text { PLCT } & \text { pseudolinfomas cutâneos de células T } \\ \text { CD } & \text { cluster of differentiation } \\ \mathrm{K} & \text { kappa } \\ \lambda & \text { lambda } \\ \text { lg } & \text { imunoglobulinas } \\ \text { Igs } & \text { imunoglobulinas de superfície } \\ P C R & \text { reação em cadeia de polimerase } \\ \text { TCR } & \text { receptor da célula T } \\ \text { HE } & \text { hematoxilina \& eosina } \\ \text { IIQ } & \text { imunoistoquímica } \\ \text { FR } & \text { framework } \\ D N A & \text { acido desoxirribonucléico } \\ \mu m & \text { micrômetro } \\ \mu l & \text { microlitro } \\ \mathrm{ml} & \text { mililitro } \\ { }^{\circ} \mathrm{C} & \text { graus Celsius } \\ U K & \text { Reino Unido } \\ \mathrm{bp} & \text { pares de base } \\ \mathrm{p} & \text { braço curto do cromossomo } \\ \mathrm{q} & \text { braço longo do cromossomo } \\ \text { IgL } & \text { cadeia leve da imunoglobulina } \\ \text { IgH } & \text { cadeia pesada da imunoglobulina } \\ & \end{array}$




\section{RESUMO}

Melotti CZ. Pesquisa do rearranjo dos genes das cadeias leve e pesada de imunoglobulina nos processos linfoproliferativos cutâneos de célula $B$ [tese]. São Paulo: Faculdade de Medicina, Universidade de São Paulo; 2007. 89p.

INTRODUÇÃO: O diagnóstico diferencial dos processos linfoproliferativos cutâneos de célula B permanece um desafio para patologistas, dermatologistas, hematologistas e oncologistas, apesar dos recentes avanços imunoistoquímicos e moleculares. OBJETIVO: Este trabalho avaliou o auxílio diagnóstico e as limitações da pesquisa da clonalidade utilizando a biologia molecular nos linfomas primários cutâneos de célula $B$ e pseudolinfomas de células $B$, assim como a relevância da análise dos dados em conjunto com informações clínicas, histológicas e imunoistoquímicas. MÉTODOS: O estudo incluiu 31 casos de processos linfoproliferativos cutâneos de célula $\mathrm{B}$ classificados à histologia e imunoistoquímica como 14 linfomas, 6 pseudolinfomas e 11 casos inconclusivos. A pesquisa da clonalidade foi realizada em todos os casos por meio da pesquisa do rearranjo dos genes da cadeia leve kappa e pesada utilizando o método de $P C R$. RESULTADOS: Os resultados confirmaram monoclonalidade em $61,5 \%$ dos linfomas. Em adição, o método evidenciou monoclonalidade em $20 \%$ dos casos inconclusivos à avaliação histológica e imunoistoquímica. A pesquisa do rearranjo dos genes de cadeia leve kappa resultou mais contributiva em relação à pesquisa do rearranjo dos genes da cadeia pesada. CONCLUSÕES: Estes resultados demonstraram a utilidade do método no auxilio diagnóstico dos linfomas cutâneos. A maior contribuição no estudo da clonalidade dos processos linfoproliferativos cutâneos de células $B$, através da pesquisa do rearranjo dos genes de cadeia leve kappa em associação com a pesquisa do rearranjo dos genes de cadeia pesada, sugeriu a necessidade da utilização conjunta das duas técnicas para maior acurácia diagnóstica nestes casos.

Descritores: linfócitos B, linfoma / diagnóstico, reação em cadeia da polimerase, cadeias leves de imunoglobulina, cadeias pesadas de imunoglobulina, pseudolinfoma, pele. 


\section{SUMMARY}

Melotti CZ. Detection of immunoglobulin light and heavy chain genes rearrangements in cutaneous $B$ cell lymphoproliferative infiltrates [thesis]. São Paulo: "Faculdade de Medicina, Universidade de São Paulo"; 2007. 89p.

INTRODUCTION: The differential diagnosis of the lymphoproliferative B-cell infiltrates remains an important challenge for pathologists, dermatologists, hematologists and oncologists, despite the recent advances in immunohistochemical and molecular techniques. OBJECTIVES: This study has evaluated the diagnostic aid and the limitations of the clonality analysis using molecular biology in cutaneous B-cell lymphomas and pseudolymphomas, as well as the relevance of this analysis when combined with clinical, histological and immunohistochemical data. METHODS: The study covered 31 cases of cutaneous lymphoproliferative B-cell infiltrates classified by histological and immunohistochemical characteristics as 14 lymphomas, 6 pseudolymphomas and 11 non-conclusive cases. The clonality analysis was performed in all cases using PCR to detect the pattern of immunoglobulin light kappa and heavy chains gene rearrangements. RESULTS: The results have confirmed monoclonality in $61,5 \%$ of lymphomas. In addition, the method showed monoclonality in $20 \%$ of the cases previously classified as a non-conclusive through histological and immunohistochemical evaluation. CONCLUSION: These results highlight the importance of the PCR clonality analysis as an ancillary diagnostic tool in cutaneous lymphoma. The research of the immunoglobulin light kappa gene rearrangement was more efficient resulting in a higher rate of monoclonality detection when compared to the heavy chain analysis. Nevertheless, the use of both protocols improves the sensitivity of the method.

Descriptors: B lymphocytes, lymphoma / diagnostic, polymerase chain reaction, immunoglobulin light chains, immunoglobulin heavy chains, pseudolymphomas, skin. 
INTRODUÇÃO 


\section{INTRODUÇÃO}

O termo "processo linfoproliferativo cutâneo" define um grupo de doenças com proliferação tecidual de linfócitos que inclui os linfomas cutâneos primários e os pseudolinfomas cutâneos. Embora intensamente estudadas nas últimas décadas, o diagnóstico diferencial entre estas duas entidades permanece um desafio para patologistas, dermatologistas, hematologistas e oncologistas, apesar dos avanços recentes na compreensão de seus aspectos histológicos, imunoistoquímicos e moleculares [1-7].

Os linfomas cutâneos primários correspondem aos processos cutâneos linfoproliferativos malignos, enquanto os pseudolinfomas cutâneos correspondem aos processos linfoproliferativos reativos benignos, que simulam clínica e histologicamente linfomas [5,8-10].

Os linfomas cutâneos primários pertencem ao grupo dos linfomas não-Hodgkin extranodais e são divididos em dois grandes grupos, linfomas cutâneos primários de célula T/NK (LCCT)/(LCCT/NK) e 
linfomas cutâneos primários de célula B ( $L C C B)$, segundo suas células de origem $[8,10-19]$.

O diagnóstico dos processos linfoproliferativos cutâneos de células B é realizado, principalmente, através da biópsia da pele lesada para o estudo histológico e imunoistoquímico. A biologia molecular, por meio da pesquisa do rearranjo dos genes das cadeias leve e pesada de imunoglobulina, tem sido utilizada na tentativa de auxiliar e corroborar o diagnóstico destas enfermidades $[1,20,21]$.

\subsection{OBJETIVOS}

Este trabalho analisa o perfil da clonalidade nos processos linfoproliferativos cutâneos de células B, classificados como: linfomas, pseudolinfomas ou inconclusivos, através de critérios histológicos e imunoistoquímicos, de pacientes acompanhados no Ambulatório de Oncologia Cutânea da Divisão de Dermatologia do Hospital das Clínicas da Faculdade de Medicina da Universidade de São Paulo (HCFMUSP), com os objetivos de:

1. Verificar a contribuição e limitações diagnósticas da pesquisa de clonalidade utilizando-se o estudo do rearranjo dos genes das cadeias leve e pesada de imunoglobulina. 
2. Comparar a taxa de sucesso diagnóstico dos métodos de pesquisa do rearranjo dos genes das cadeias leve e pesada de imunoglobulina.

3. Avaliar a importância do resultado da pesquisa da clonalidade no contexto clínico, histológico e imunoistoquímico para o diagnóstico de LCCB. 
REVISÃO DA LITERATURA 


\section{REVISÃO DA LITERATURA}

\subsection{PROCESSOS LINFOPROLIFERATIVOS CUTÂNEOS DE CÉLULAS B E LINFOGÊNESE}

A pele é o maior órgão em extensão do corpo humano e um sistema de barreira entre o organismo e o meio externo, participando ativamente nas respostas imunes e reações inflamatórias. A população celular envolvida na resposta imune da pele é formada principalmente por ceratinócitos, células de Langerhans e linfócitos T. Todas as células expressam em sua superfície ou em seu interior moléculas (antígenos) que as identificam. A partir do reconhecimento dessas moléculas foi possível classificar e estudar o papel dos linfócitos T e B nos processos fisiológicos e neoplásicos. Muitas dessas moléculas, convencionalmente denominadas CD (cluster of differentiation), são identificadas por anticorpos monoclonais ou policlonais [22].

Muitas questões ainda não foram elucidadas quanto ao papel dos linfócitos B no sistema imune da pele. Entretanto, até o momento, trabalhos sugerem que os linfócitos B não pertençam à população celular 
da pele em situação fisiológica [23]. Estes são produzidos e maturados na medula óssea, permanecendo nos órgãos linfóides periféricos (linfonodo e baço), assim como nas mucosas e medula óssea. Em resposta a estímulos antigênicos (à distância), os linfócitos B podem migrar para outros órgãos [22].

A linfogênese $B$, origem e maturação das células $B$, inicia-se na medula óssea com células predestinadas à linhagem celular B, chamadas células pró-B. As células pró-B não produzem imunoglobulinas (lg), porém, expressam em sua superfície moléculas que as caracterizam, denominadas CD19, CD34, CD25 e CD10 [24]. Na seqüência da maturação celular encontram-se as células pré-B, que sintetizam cadeias pesadas citoplasmáticas $\mu$ e cadeias leves substitutivas, além de estruturas homólogas às cadeias leves de imunoglobulina kappa (K) e lambda $(\lambda)$. As células pré-B também expressam CD10, CD19 e CD20. O próximo estágio da maturação ocorre com a produção das verdadeiras cadeias leves $\mathrm{k}$ e $\lambda$ de imunoglobulina. As células pró-B e pré-B são chamadas de linfoblastos B precursores [22,25].

Através de rearranjo dos genes das cadeias leve e pesada de imunoglobulinas e da expressão das diferentes classes de imunoglobulinas de superfície (Igs), têm origem as células B naive (ou virgem, não exposto a antígenos). As células $B$ naive são pequenos linfócitos que circulam no sangue periférico e também ocupam os folículos 
linfóides primários e as zonas do manto folicular. Expressam freqüentemente CD20, CD19, CD5, CD23, IgMs* e IgDs ${ }^{* *}$. Com a exposição das células B naive a antígenos, estas sofrem transformação blástica, proliferação e maturação, dando origem às células plasmáticas secretoras de imunoglobulinas e células B de memória. Os linfomas de células $B$ são proliferações clonais de células $B$, em seus diversos estágios de diferenciação. A população celular neoplásica deriva de uma única célula, apresentando assim um único rearranjo do gene de imunoglobulina, chamada de população monoclonal [22].

Os linfócitos $\mathbf{T}$ também são produzidos na medula óssea, mas sofrem maturação no timo. Após maturação circulam constantemente na forma naive pelo sangue e órgãos linfóides periféricos. Quando apresentados a antígenos na pele, linfócitos efetores e linfócitos de memória, expressam marcadores em sua superfície que os tornam "participantes" do sistema imune desse órgão [22].

\subsection{LINFOMAS CUTÂNEOS}

Os linfomas são divididos em dois grandes grupos: o linfoma de Hodgkin e os linfomas não-Hodgkin. O linfoma de Hodgkin acomete principalmente linfonodos cervicais em indivíduos adultos. A incidência absoluta do linfoma de Hodgkin aparentemente não tem se modificado, em 
contraste com o evidente aumento da incidência dos linfomas não-Hodgkin [21]. Os linfomas cutâneos primários pertencem ao grupo dos linfomas não-Hodgkin extranodais, linfomas que acometem primariamente locais que não o linfonodo. A pele é o segundo local de acometimento extranodal, correspondendo a $25 \%$ dos linfomas não-Hodgkin extranodais, seguindo o trato gastrointestinal [21]. Os linfomas cutâneos primários diferem significantemente das formas nodais equivalentes quanto ao comportamento clínico e prognóstico [4].

No passado os linfomas cutâneos não eram reconhecidos como entidade própria, e sim como acometimento secundário da pele por linfoma nodal. Inicialmente, somente a micose fungóide, linfoma cutâneo de células $\mathrm{T}$, foi reconhecida como forma primária de linfoma cutâneo. Os primeiros relatos de linfomas cutâneos primários, não micose fungóide, foram publicados nas décadas de 60 e 70. Com base nas características imunofenotípicas das células neoplásicas, ao final dos anos 70 , os linfomas foram divididos em dois grandes grupos, linfomas de células T e linfomas de células B, segundo suas células de origem. Nos anos 80 e 90 surgiu o conceito de linfomas cutâneos primários e secundários, e a seguir várias classificações foram descritas [21,26,27]. 


\subsubsection{EPIDEMIOLOGIA}

As incidências anuais relatadas dos linfomas B por país, incluindo os linfomas nodais e extranodais, são muito variadas. Nos EUA a incidência é de aproximadamente 15 por 100.000 habitantes, na China 1,2 por 100.000 habitantes. América do Sul, África e Japão apresentam incidências intermediárias [28] .

Os LCCB são menos freqüentes que os LCCT, com incidência consideravelmente variável entre a Europa (20 a 25\% de todos os linfomas cutâneos) e os EUA (aproximadamente de 3 a 7\%). Apresentam prevalência no sexo masculino (2:1) e maior incidência na sexta década de vida [23,29]. As taxas de incidência dos linfomas não-Hodgkin extranodais têm demonstrado aumento nos últimos anos. Este fato também poderia decorrer dos avanços dos métodos diagnósticos como a imunofenotipagem e imunogenotipagem [23].

\subsubsection{CLASSIFICAÇÃO DOS LINFOMAS CUTÂNEOS}

A classificação dos linfomas vem sendo discutida e modificada nas últimas décadas. A classificação Rappaport foi utilizada para os linfomas até os anos 70, e não contemplava os linfomas cutâneos [6]. Com as classificações Kiel [6,30], Lukes-Collins [31] e Working Formulation, os linfomas extranodais puderam ser melhor avaliados. Na década de 90 
surgiram três novas classificações: REAL - Revised European-American Lymphoid Neoplasm Classification [15], E.O.R.T.C. - European Organization for Research and Treatment of Cancer [17] e WHO - World Health Organization [25].

Recentemente, WHO e EORTC, propuseram a classificação consensual para os linfomas cutâneos, abrangendo aspectos histopatológicos, imunoistoquímicos, moleculares e clínicos [19]. A WHO-EORTC divide os linfomas cutâneos em: (i) LCCT/NK; (ii) LCCB; e (iii) Neoplasias hematológicas precursoras [17]. Para os LCCB, WHO-EORTC os separam em cinco entidades: (i) linfoma cutâneo de célula B da zona marginal (LCCB da zona marginal), (ii) linfoma cutâneo de célula B centro-folicular (LCCB centro-folicular), (iii) linfoma cutâneo difuso de grande célula B - tipo perna (LCDGCB, tipo perna), (iv) linfoma cutâneo difuso de grande célula B, outro - não perna (LCDGCB, outro) e (v) Linfoma Cutâneo intravascular de grande célula B (LCGCB intravascular) (Quadro 1).

Quadro 1. Classificação WHO-EORTC para os linfomas cutâneos de célula B (Blood 2005)

\section{Linfomas Cutâneos de Célula B}

LCCB da zona marginal

LCCB centro-folicular

LCCB difuso de grande célula $B$, tipo perna

LCCB difuso de grande célula $B$, outro (não perna)

LCCB intravascular de grande célula $B$ 


\subsubsection{ASPECTOS CLÍNICOS E PROGNÓSTICO}

Clinicamente, os LCCB apresentam-se como pápulas, placas ou nódulos, com predomínio das lesões em placas e nódulos; de coloração eritematosa a violácea [26,32-34]. As lesões podem ser solitárias ou múltiplas; disseminadas ou mais freqüentemente agrupadas com preferência em uma região corpórea, e raramente apresentam ulceração ou necrose. Quanto à localização, podem acometer qualquer área da superfície corpórea, entretanto, alguns subtipos apresentam áreas de predileção, como será exposto a seguir $[32,35,36]$.

\section{O linfoma cutâneo de célula B da zona marginal (LCCB da zona} marginal) apresenta-se habitualmente como lesões únicas ou múltiplas agrupadas; com predileção por tronco e membros superiores, acometendo também cabeça e pescoço [35,37]. O acometimento extracutâneo é extremamente raro. Entretanto, a recorrência cutânea das lesões é freqüente, assim como regressão espontânea tem sido observada [38]. A ulceração é incomum. A associação com a infecção pela Borrelia burgdorferi tem sido descrita na Europa [39-43]. O imunocitoma cutâneo e a hiperplasia linfóide folicular com células plasmáticas monotípicas, assim como os raros casos de plasmocitoma não associado ao mieloma múltiplo (plasmocitoma extramedular da pele), estão incluídos neste grupo. Séries de casos demonstram ótimo prognóstico da entidade, com $100 \%$ de sobrevida em 5 anos $[19,44-46]$. 
O linfoma cutâneo de célula B centro-folicular (LCCB centrofolicular), incluído-se neste grupo os linfomas previamente classificados pela WHO como linfoma folicular e linfoma difuso de grande célula, apresenta-se como placas ou tumores com predileção por cabeça (couro cabeludo e região frontal) e tronco [37,47]. Usualmente, apresenta distribuição regional. Os raros casos com distribuição disseminada não apresentam relação com prognóstico desfavorável [48]. O linfoma descrito no passado como linfoma de Crosti ou "reticulo-histiocitoma do dorso", caracterizado por lesão na região dorsal, usualmente nódulo ou placa, corresponde ao LCCB centro-folicular [19,49]. O padrão folicular sugere melhor prognóstico com $95 \%$ de sobrevida em 5 anos. O padrão de crescimento difuso e a positividade para bcl-2 relacionam-se com prognóstico menos favorável $[19,35,37,50]$.

O linfoma cutâneo difuso de grande célula B - tipo perna (LCDGCB, tipo perna), entidade reconhecida inicialmente somente pela EORTC, atualmente foi incorporada pela classificação consensual WHOEORTC. Predominantemente, afeta indivíduos idosos e particularmente do sexo feminino. Acomete membro inferior abaixo do joelho, freqüentemente um único membro, podendo apresentar, raramente, o comprometimento bilateral. As lesões podem ser solitária ou múltiplas agrupadas [37,48,51]. Em contraste com o grupo dos LCCB centro-folicular, este grupo apresenta mais freqüentemente disseminação extracutânea [48]. O prognóstico tem-se demonstrado variável, com sobrevida em 5 anos entre 36 e 100\% dos casos. 
Múltiplas lesões e acometimento dos dois membros inferiores conferem pior prognóstico ao caso $[19,35]$.

O linfoma cutâneo difuso de grande célula B, outro - não perna (LCDGCB, outro) apresenta características clinicas similares ao grupo do LCCB da zona marginal e LCCB centro-folicular, acometendo cabeça, pescoço, tronco e membros inferiores. Estão incluídos neste grupo raros casos que não completam critérios para a classificação como LCCB centrofolicular, assim como para LCDGCB, tipo perna [19].

O linfoma cutâneo intravascular de grande célula B (LCGCB intravascular) entidade rara e de comportamento agressivo. Caracteriza-se por placas ou áreas enduradas, dolorosas, sugestivas de paniculite ou púrpura, que acomete tronco e membros inferiores. Pode acometer também sistema nervoso central e pulmão [35]. O prognóstico é reservado para o acometimento extra-cutâneo associado ( $22 \%$ de sobrevida em 3 anos) e mais favorável para acometimento exclusivamente cutâneo (56\% de sobrevida em 3 anos) [52]. Alguns autores, pela raridade dos LCGCB intravascular, já o inserem no grupo miscelânea dos LCDGC, outro [38].

\subsubsection{ASPECTOS HISTOLÓGICOS E IMUNOISTOQUÍMICOS}

A confirmação diagnóstica do linfoma cutâneo, apesar da utilização da histopatologia e da imunoistoquímica, em muitos casos permanece 
extremamente difícil. O diagnóstico da neoplasia é habitualmente sugerido por patologistas experientes através da avaliação citomorfológica e da disposição do arranjo arquitetural do infiltrado. Histologicamente, a hematoxila-eosina (HE), observa-se proliferação de linfócitos B neoplásicos, distribuídos difusamente ou formando arranjos nodulares, preferencialmente na derme profunda, chamada de padrão bottom-heavy. O infiltrado é predominantemente heterogêneo, formado por linfócitos pequenos e grandes, observando-se, menos freqüentemente, a presença isolada de linfócitos grandes, característica esta que favorece e facilita o diagnóstico de LCCB [32,53]. Observa-se freqüentemente presença de faixa normal de colágeno na derme superficial (zona Grenz), e ausência de epidermotropismo e angiocentrismo [54].

Atualmente, para a classificação dos linfomas é imprescindível a realização do estudo imunoistoquímico, cujo painel de anticorpos é racionalizado conforme os achados histológicos. Inicialmente, visa discriminar se o infiltrado é composto por linfócitos B ou T/NK. Secundariamente, será auxiliar na classificação dos linfomas dos dois grandes grupos (B e T/NK). É ainda importante a distinção do fenótipo das células de interesse (células neoplásicas), daquele do infiltrado reativo (células inflamatórias reacionais).

Os linfócitos B são células CD3-, CD19 ${ }^{+}, \mathrm{CD}^{-} \mathrm{C}^{+}$e $\mathrm{CD}^{-} \mathrm{Ca}^{+}$. Os linfócitos $B$ do centro germinativo são $C D 19^{+}, C D 20^{+}, C D 79 a^{+}$e $C D 10^{+}$, já os 
linfócitos $\mathrm{B}$ da zona marginal são $\mathrm{CD} 19^{+}, \mathrm{CD}^{2} 0^{+}, \mathrm{CD} 7 \mathrm{a}^{+}$e $\mathrm{CD} 10^{-}$. Os plasmócitos, habitualmente, são $\mathrm{CD}^{-} 9^{-}, \mathrm{CD}^{-} 0^{-}$e $\mathrm{CD} 79 \mathrm{a}^{+}$. Outros marcadores complementares são importantes auxiliares diagnósticos ou classificatórios como anti-CD23, anti-ALK, anti-EMA, anti-CD4, anti-CD8, além dos anticorpos anti-bcl-2, anti-bcl-6, anti-MUM1, anti-OCT2 e anti-Ki-67 [12,24,32,51,55,56]. Já o painel utilizado para a marcação de células T é composto, principalmente, por anticorpos anti-CD3, CD43, e CD45RO; para células NK são anti-CD16 e CD56 [57,58].

A pesquisa das cadeias leves de imunoglobulina (kappa e lambda), por meio da imunoistoquímica, pode ser utilizada na determinação da clonalidade das populações linfocitárias, auxiliando no diagnóstico diferencial entre LCCB e PLB. Entretanto, dificuldades inerentes aos marcadores e à técnica usualmente empregada comprometem a confiabilidade do método $[20,59]$.

Trabalhos recentes indicam o importante papel dos marcadores imunoistoquímicos para o diagnóstico, e também para avaliar prognóstico nos linfomas cutâneos, principalmente nos casos dos linfomas de grandes células. A positividade de bcl-2, OCT2 e MUM1 esta relacionada ao pior prognóstico, enquanto bcl-6 positivo apresenta relação com prognóstico mais favorável [60-62]. 
O LCCB da zona marginal apresenta-se histologicamente como um infiltrado linfocitário difuso, nodular ou formando áreas perivasculares e perianexiais, acometendo da derme até o tecido subcutâneo. Um "padrão inverso" àquele observado nos centros germinativos é descrito para o infiltrado linfocitário no linfoma da zona marginal. Apresenta-se com um centro mais escuro formado por pequenos linfócitos, circunscrito por uma área mais clara formada por células de tamanho médio e citoplasmas abundantes, que se assemelham aos centrócitos. Os centros germinativos reacionais estão presentes freqüentemente. $O$ infiltrado celular das áreas interfoliculares pode ser composto por pequenos linfócitos, células plasmáticas, linfoplasmocitóides, monócitos, eosinófilos e ocasionalmente blastos $[37,63,64]$. O estudo imunoistoquímico evidencia células neoplásicas $\mathrm{CD}^{2} 0^{+}, \mathrm{CD} 79 \mathrm{a}^{+}, \mathrm{bcl}-2^{+}, \mathrm{CD}^{\circ} 0^{-}, \mathrm{CD}^{-} \mathrm{e}$ bcl-6. Entretanto os centros germinativos reacionais são freqüentemente bcl-6 ${ }^{+}, \mathrm{CD} 10^{+}$e bcl-2- $[65]$.

O LCCB centro-folicular apresenta-se como infiltrado nodular a difuso e caracteriza-se por padrão de crescimento folicular e/ou padrão de crescimento difuso, formado por centrócitos e centroblastos neoplásicos, além de imunoblastos, pequenos linfócitos, histiócitos, eosinófilos e células plasmáticas [66]. Figuras de mitose podem ser freqüentes. Folículos linfóides reacionais lembrando centros germinativos podem estar presentes e, muitas vezes, dificultar o diagnóstico diferencial com os pseudolinfomas. Nos estágios iniciais e pequenas lesões o padrão de crescimento folicular é 
predominante e com a progressão das lesões tumorais o infiltrado caracteriza-se por células maiores. A redução das células $\mathrm{T}$ reacionais também é observada com a progressão da doença [67]. Imunoistoquimicamente, no padrão folicular as células neoplásicas são $\mathrm{CD}^{+}{ }^{+}, \mathrm{CD} 9 \mathrm{a}^{+}, \mathrm{CD} 10^{+}$e bcl-6 ${ }^{+}$. A expressão de CD10 é, habitualmente, negativa no padrão difuso. Apresentam também $\mathrm{CD5}^{-}, \mathrm{CD}^{-} 3^{-}$e bcl-2${ }^{-}$ (raramente positivos) $[51,65]$.

O LCDGCB - tipo perna, apresenta infiltrado denso de grandes células na derme e tecido subcutâneo, formado por centroblastos, imunoblastos e, grandes centrócitos. Epidermotropismo simulando linfoma de células $T$ pode estar presente e figuras de mitose são freqüentes. A imunoistoquímica as células neoplásicas são $\mathrm{CD}^{2} 0^{+}$e $\mathrm{CD} 79 \mathrm{a}^{+}$. Em contrataste com os LCCB centro-folicular, o grupo dos LCDGCB - tipo perna apresentam positividade para bcl-2 e bcl-6 na maioria dos casos. São freqüentemente CD10 negativos, entretanto freqüentemente expressam MUM1 / IRF4 e OCT2 [24,50,51,56].

o LCDGCB - outro, reunindo os casos que não completam critérios para a classificação como LCCB centro-folicular e LCDGCB, tipo perna geralmente corresponde aos linfomas B difuso de grande célula, variante anaplásico, variante plasmacítico, variante linfoma de célula B rico em célula T, ou ainda os linfomas sistêmicos com acometimento cutâneo [19]. 
O LCGCB intravascular apresenta numerosos vasos sanguíneos dilatados na derme e tecido subcutâneo, com presença de grandes células linfóides neoplásicas confinadas na luz de vênulas, capilares e arteríolas. As células neoplásicas são $\mathrm{CD}_{2} \mathrm{O}^{+}, \mathrm{CD} 79 \mathrm{a}^{+}, \mathrm{bcl}-2^{+}, \mathrm{bcl}-6^{+}$e freqüentemente $\mathrm{CD}^{-} 0^{-}[19]$.

\subsection{PSEUDOLINFOMAS}

Assim como os linfomas, os pseudolinfomas podem decorrer da proliferação de linfócitos T ou B $[37,68]$. O pseudolinfoma cutâneo de células B caracteriza-se pela presença de infiltrado cutâneo linfocitário reativo que simula, clínica e histologicamente, linfomas cutâneos.

Relatam-se como agentes causais a Borrelia burgdorferi, pigmentos de tatuagem, herpes-vírus, picadas por insetos, vacinas e drogas [69]. Entretanto, os PLB mais freqüentemente são idiopáticos $[4,27,70]$. Termos como linfocitoma cutis, linfadenosis benigna cutis, hiperplasia linfóide cutânea, infiltrado linfocitário benigno são sinônimos de pseudolinfoma cutâneo $[27,37,68,71]$. A doença de Kimura e a doença de Castleman são consideradas como hiperplasias linfóides nodais de células B que podem acometer a pele $[70,72]$. 
Evidências sugerem que os pseudolinfomas e linfomas cutâneos de baixo grau pertencem a um "espectro" de processos linfoproliferativos de células $B$, onde o primeiro passo da desordem seria um processo inflamatório reacional (pseudolinfoma) evoluindo até o estado neoplásico maligno (linfoma). Este fato poderia explicar a grande dificuldade na diferenciação das duas entidades nos estágios iniciais e intermediários desse processo $[23,73,74]$. Outro importante dado a ser ressaltado é o papel dos processos inflamatórios crônicos na carcinogênese, relatada em estudos recentes, principalmente quanto à participação dos linfócitos $B$ neste processo [73]. Comprovadamente, a incidência de câncer está aumentada em indivíduos portadores de processos inflamatórios crônicos, como pancreatites, colites, doença de Crohn, e infecções pelo HPV. Muitos mecanismos da carcinogênese ainda precisam ser elucidados, entretanto, modelos associando a ativação de linfócitos B através de processos inflamatórios crônicos e a progressão neoplásica já foram bem definidos. Assim como, estudos sugerem que intervenções farmacológicas atenuando a ativação ou bloqueando o recrutamento de linfócitos B poderiam prevenir a progressão de processos pré-malignos epiteliais [73].

\subsubsection{EPIDEMIOLOGIA}

A incidência e a prevalência dos pseudolinfomas cutâneos de células B são pouco relatadas [27,75]. Estudos realizados nas décadas de 
60 e 70 indicam uma maior incidência no sexo masculino na proporção de 2:1, acometendo indivíduos com idade média de 34 anos [5,71].

\subsubsection{CLASSIFICAÇÃO DOS PSEUDOLINFOMAS}

Não existe classificação consensual para os pseudolinfomas. No Quadro 2, observa-se a classificação dos pseudolinfomas de células B e T, segundo o Tratado de Dermatologia em Medicina de Fitzpztrick [70].

Quadro 2 - Classificação dos pseudolinfomas de células B e T

\begin{tabular}{|l|l|}
\hline Subtipo Clínico-patológico & Infiltrado celular predominante \\
\hline Hiperplasia cutânea linfóide & Células B ou T \\
Doença de Kimura & Células B \\
Doença de Castleman & Células B \\
Granulomatose linfomatóide* & Células B \\
\hline Pseudo-micose fungóide & Células T \\
Mucinose folicular & Células T \\
Dermatite de contato linfomatóide & Células T \\
Reticulóide actínico & Células T \\
Papulose linfomatóide* & Células T \\
Linfoadenopatia angioimunoblástica & Células T \\
Infiltração linfocitária da pele & Células T \\
\hline
\end{tabular}

*incluídas como linfoma cutâneo de células T na classificação WHO-EORTC (2005).

\subsubsection{ASPECTOS CLÍNICOS E PROGNÓSTICO}

A história clínica e o exame físico colaboram no diagnóstico diferencial. Entretanto, o diagnóstico é realizado essencialmente por meio do 
estudo histológico e imunoistoquímico [36,76,77]. A biologia molecular tem sido descrita como método auxiliar importante no diagnóstico nesses processos $[78-80]$.

Clinicamente, as lesões dos pseudolinfomas de células B são semelhantes às lesões dos linfomas cutâneos primários de células B. As apresentações clínicas mais freqüentes são pápulas, seguidas de nódulos ou placas, eritemato-violáceas, infiltradas e de diâmetro freqüentemente menor que $1 \mathrm{~cm}$ [32]. As lesões podem ser solitárias ou múltiplas, sem predileção por local de acometimento. A literatura enfatiza a importância da história clínica na busca de exposição aos agentes causais [27,37,81].

A doença de Kimura, atualmente classificada por alguns autores como pseudolinfoma, apresenta-se com nódulos cutâneos e subcutâneos solitários ou múltiplos, acometendo principalmente cabeça e pescoço. O envolvimento dos linfonodos e eosinofilia periférica é observada [70]. Hiperplasia angiolinfóide com eosinofilia, caracterizada pela presença de nódulos, placas e pápulas, usualmente menores que dois centímetros, é reconhecida por alguns autores como uma doença distinta e não como sinônimo da doença de Kimura. Outros acreditam que a doença de Kimura e a hiperplasia angiolinfóide com eosinofilia fazem parte do espectro de uma mesma doença $[82,83]$. Casos de hiperplasia angiolinfóide com eosinofilia e acometimento sistêmico são descritos na literatura, especialmente o acometimento pulmonar cursando com quadros asmáticos [84]. 
O prognóstico dos pseudolinfomas cutâneos é excelente, na grande maioria dos casos não alterando a sobrevida. Entretanto, é importante ressaltar que pseudolinfomas associados à Borrelia burgdorferi e a doença de Kimura) / hiperplasia angiolinfóide com eosinofilia podem apresentar acometimento extracutâneo, e assim influenciar a sobrevida dos portadores $[73,83-86]$.

\subsubsection{ASPECTOS HISTOLÓGICOS E IMUNOISTOQUÍMICOS}

Os pseudolinfomas apresentam, geralmente, infiltrado celular nodular ou difuso, que tende a ser relativamente simétrico e mais intenso na derme superficial, chamado de padrão top-heavy [27,37]. A epiderme freqüentemente encontra-se conservada; entretanto, ocasionalmente, observa-se hiperceratose, paraceratose, acantose, espongiose ou degeneração vacular da camada basal. Plasmócitos, eosinófilos, neutrófilos e células gigantes podem ser observadas no infiltrado celular. A presença de estruturas denominadas folículos linfóides secundários são achados freqüentes na derme. O folículo linfóide é caracterizado por nódulos formados, na área central, por pequenas e grandes células e, na periferia, por pequenas células, esboçando um típico centro germinativo com ausência de pleomorfismo. $[27,70]$.

Os pseudolinfomas apresentam à imunoistoquímica, freqüentemente, infiltrado celular composto por células B (CD20 positivas) e 
também células $\mathrm{T}$ (CD3 ou CD45RO positivas). A presença da policlonalidade do infiltrado celular nos pseudolinfomas cutâneos, como descrita anteriormente, também pode ser avaliada através da imunoistoquímica.

Outra importante função da imunoistoquímica, no auxílio diagnóstico para os pseudolinfomas, se dá na identificação e estudo mais detalhado dos folículos linfóides secundários. A atividade de proliferação celular nos folículos tem sido descrita como auxiliar na distinção entre os processos benignos e malignos, avaliada através de marcadores de proliferação celular (Ki67 / MIB-1). A baixa atividade de proliferação é observada principalmente nos casos de linfomas, enquanto alta atividade proliferativa é observada nos pseudolinfomas [54]. Usualmente, pode-se observar também a presença de células dendríticas (CD23 ou CD21 positivas) no centro dos folículos, esboçando o arcabouço folicular (folículos anteriormente ativos e inativos no momento) nos pseudolinfomas $[27,54,70,75]$.

\subsection{BIOLOGIA MOLECULAR}

Recentemente, a pesquisa do rearranjo de genes das cadeias leve e pesada da imunoglobulina das células B, por meio da biologia molecular, tem sido utilizada como método auxiliar no diagnóstico diferencial entre LCCB e PLB $[87,88]$. Cada célula B possui genes que codificam as cadeias 
leve e pesada das imunoglobulinas com seqüências específicas de nucleotídeos para suas regiões: região variável $(V)$, região de junção $(J)$, região de diversidade (D) e região constante (C) [22] (Figura 1).

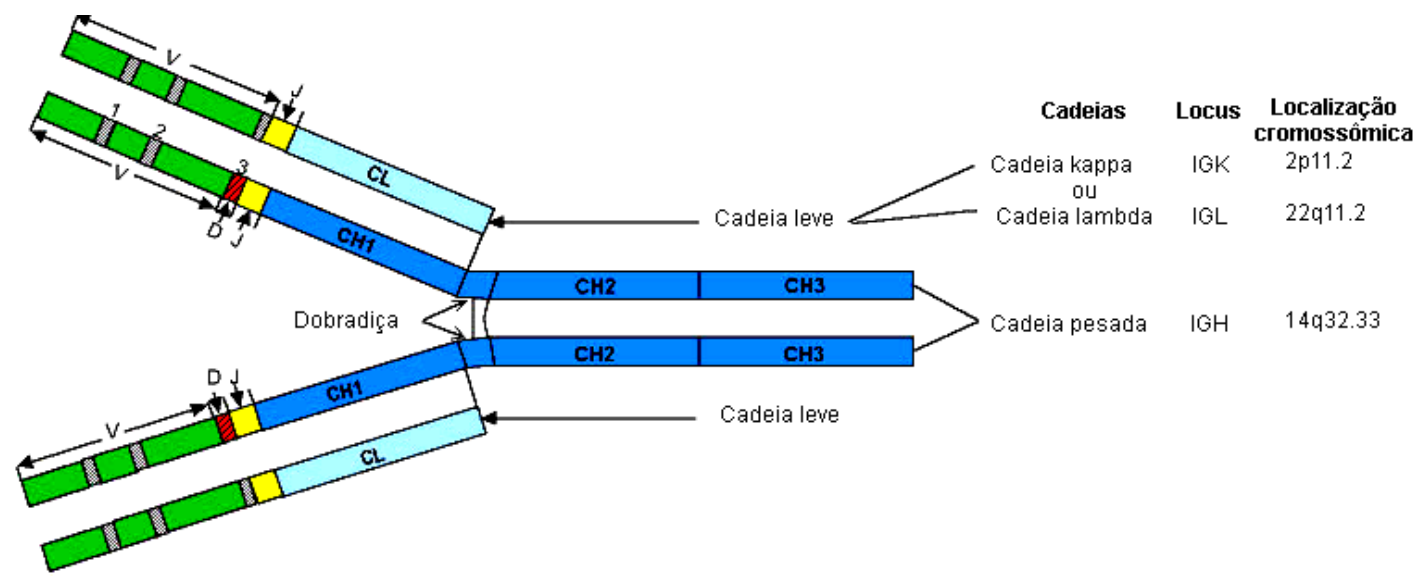

Figura 1. Esquema das cadeias leves $(\lg L)$ e pesadas $(\lg H)$ da imunoglobulina (FONTE: Lefranc, MP. Nucleic Acids Res, 2005)

Os rearranjos dos genes das cadeias pesadas e leves das imunoglobulinas ocorrem em situações fisiológicas para a produção de inúmeros anticorpos (imunoglobulinas formadas em resposta a antígenos). Cada linfócito B apresenta cerca de 50.000 a 150.000 moléculas de imunoglobulinas em sua superfície. A expressão das imunoglobulinas varia de acordo com o estágio de diferenciação do linfócito B [89]. A população de linfócitos B normais apresenta fisiologicamente rearranjos diversos, caracterizando assim a proliferação policlonal. Os linfócitos neoplásicos apresentam rearranjos idênticos para os genes das imunoglobulinas, e deste modo, sua proliferação é chamada monoclonal, células originadas de um 
mesmo clone celular e que expressam moléculas de superfície comuns (Figura 2). Os PLBs apresentam caráter de proliferação policlonal, demonstrando que os linfócitos presentes apresentam caráter reativo e possuem origem de clones celulares diferentes com rearranjos diversos $[35,77,79]$.

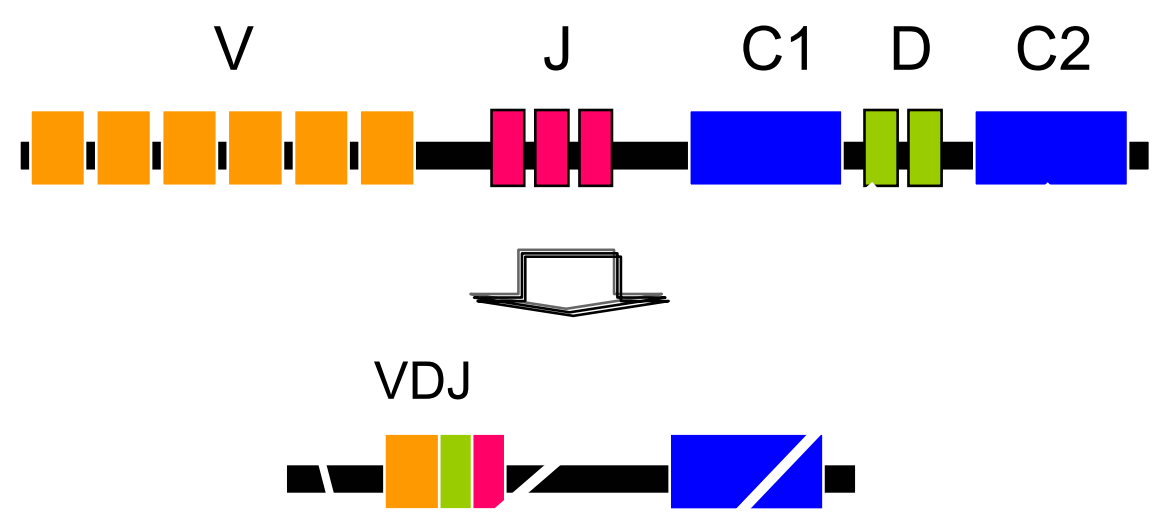

Figura 2. Rearranjo do gene da cadeia pesada da Imunoglobulina (VDJ)

A pesquisa do rearranjo dos genes de imunoglobulina é realizada usualmente através do método de $\boldsymbol{P C R}$ (reação em cadeia de polimerase), no qual segmentos de DNA são amplificados pela reação em cadeia da polimerase (Figura 3). O método $P C R$ apresenta maior sensibilidade, por demandar uma quantidade menor de DNA, como também baixo custo, pela possibilidade de execução em material fixado em formalina e incluído em parafina, quando comparado a outros métodos utilizados na pesquisa de clonalidade, como o Southern Blot [90-96]. 


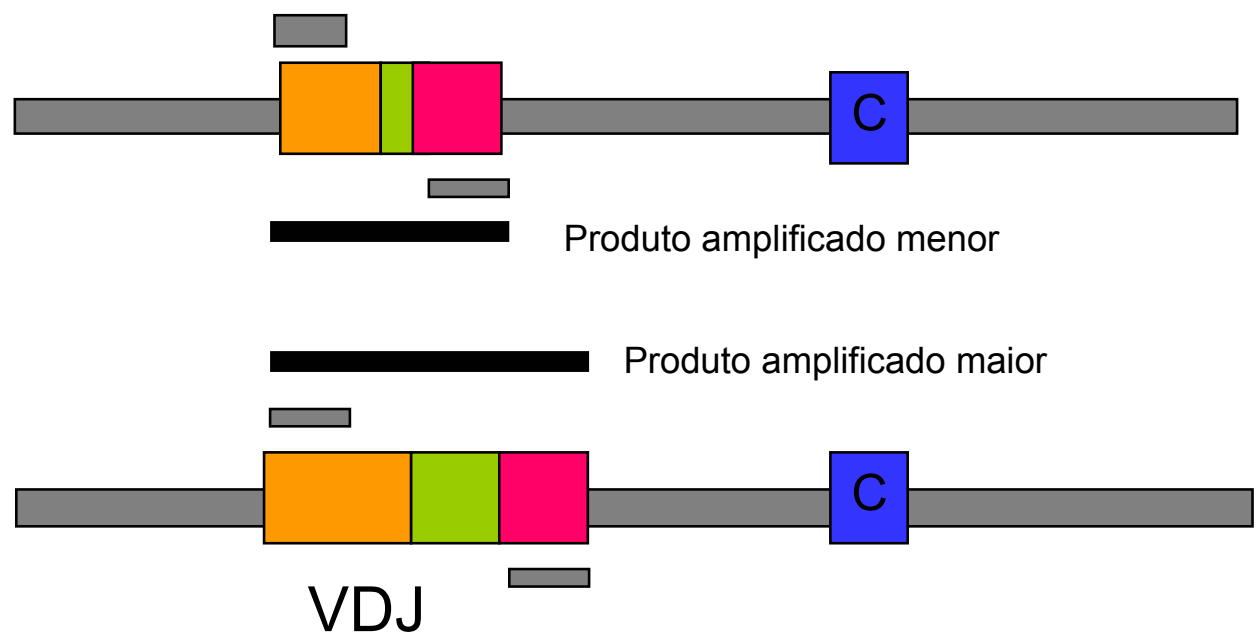

Figura 3. Amplificação do segmento do DNA alvo com produtos de diferentes pesos moleculares de acordo com o tipo de rearranjo das cadeias do gene de imunoglobulina (característica policlonal)

A pesquisa do rearranjo do gene de cadeia pesada da imunoglobulina $(\lg \mathrm{H}-\mu)$, localizado no cromossomo 14 (14q32), por meio do $P C R$, tornouse método auxiliar de grande relevância no diagnóstico dos processos linfoproliferativos de células $B[21,97,98]$. O rearranjo do gene de IgH é o primeiro evento a ocorrer na diferenciação das células $B$, precedendo 0 rearranjo dos genes da cadeia leve da imunoglobulina ( $\lg L)$, e está presente na grande maioria dos LCCB [99].

Para a realização do método do $P C R$ e amplificação do segmento especifico do DNA, onde o rearranjo será demonstrado, são utilizados primers ou iniciadores complementares das regiões denominadas framework (FR1, FR2 ou FR3), localizadas na região variável (V), e primers reversos 
(JH) localizados na região de junção $(\mathrm{J})$, assim ampliando a seqüência alvo (Figura 4) $[94,100]$.

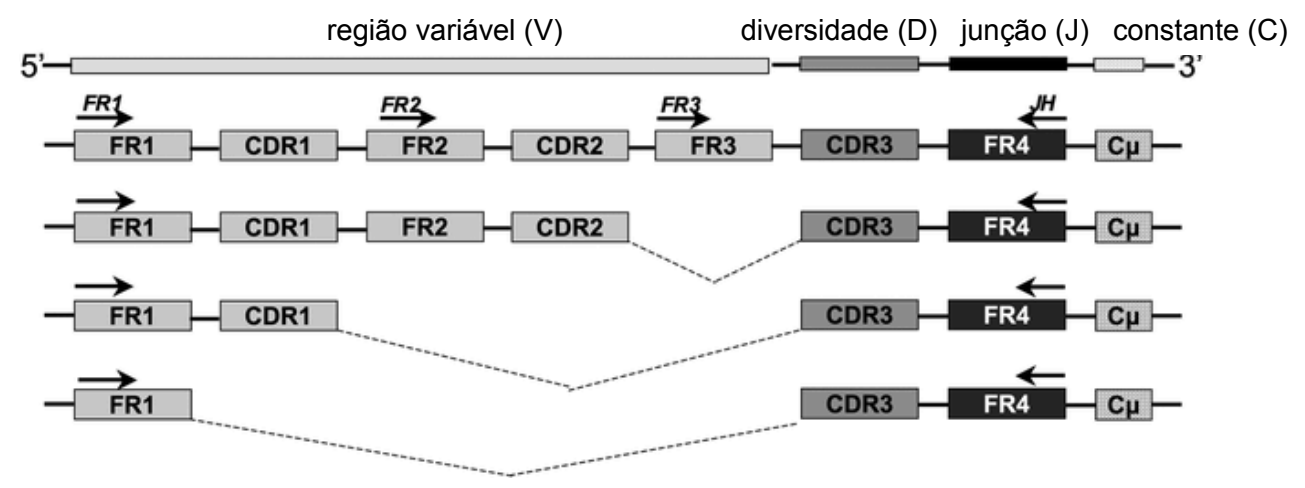

Figura 4. Esquema para a determinação do rearranjo dos genes de $\operatorname{lgH}$ (VDJ), demonstrando a utilização de um primer (iniciador) das regiões denominadas framework (FR1, FR2 ou FR3) localizado na região variável (V) e um primer reverso $\left(\mathrm{J}_{H}\right)$ localizado na região de junção $(\mathrm{J})$ (FONTE: Nikiforova, MN., et al. Arch.Pathol.Lab Med. 2007)

Uma vez que o gene de $\operatorname{lgH}$ pode ser avaliado em várias de suas regiões (FR3, FR3A, FR2, FR1), utilizando diferentes primers, vários protocolos de pesquisa do rearranjo do gene de $\mathrm{IgH}$ foram desenvolvidos (FR3 clássico - Nizet, FR3 BIOMED, FR2 BIOMED, FR1 BIOMED entre outros) [100]. A sensibilidade dos métodos apresenta grande variação, desde inferiores a $20 \%$, até superiores a $90 \%$, de acordo com recente estudo multicêntrico envolvendo vários laboratórios [101,102].

O protocolo mais utilizado para a pesquisa de clonalidade nos processos linfoproliferativos cutâneos de células B é o FR3 clássico Nizet 
e/ou FR3 BIOMED, que apresenta sensibilidade entre 50-85\% [103,104]. Entretanto, em muitos casos não é possível a amplificação do gene de $\operatorname{lgH}$, devido à perda da expressão do rearranjo de $\operatorname{lgH}$ pelos linfócitos $B$ neoplásicos ou inviabilidade do material por fixação excessiva em formalina. Nestes casos, a pesquisa do rearranjo do gene de $\lg \mathrm{L}$, kappa ( $\lg \mathrm{LK})$, com localização 2q12 e/ou lambda ( $\lg L \lambda)$ com localização 22q11, também é realizada, resultando num aumento da sensibilidade diagnóstica, que atinge até $93 \%$, particularmente quando combinada à pesquisa do rearranjo do gene da cadeia $\lg \mathrm{H}[88,103,105]$.

Estudo sobre detecção do rearranjo gênico clonal de $\operatorname{lgH}$ realizado por Nikiforava e colaboradores para o Colégio Americano de Patologia, publicado em 2007, avalia a performance de 161 laboratórios americanos de patologia na pesquisa da clonalidade em processos linfoproliferativos B não cutâneos. A pesquisa do rearranjo gênico por Southern blot é considerada padrão ouro, devido ao alto índice de especificidade. Entretanto pelo alto custo, utilização de material fresco ou congelado e necessidade de alta quantidade de DNA para a realização do Southern blot, a técnica de $P C R$ para o estudo da clonalidade é utilizada mais freqüentemente. A menor especificidade do método PCR com alto índice de falso negativo, provavelmente ocorre devido à utilização de primers incorretos (não específicos), estes não ampliando a seqüência-alvo adequada, ou ainda amplificando as seqüências alvos em adição a seqüências "não alvo". Outro fator que dificulta o sucesso do método PCR é a utilização de material 
incluído em parafina, devido à fragmentação da seqüência alvo de $D N A$, quando comparado a melhores resultados na realização do $P C R$ em material fresco ou congelado [94].

Outros aspectos genéticos têm sido estudados e relatados em estudos recentes. As translocações cromossômicas, t(14;18)(q32;q21), envolvendo gene $I G H$ no cromossomo 14 e gene $M L T$ no cromossomo 18, e também $\mathrm{t}(3 ; 14)(\mathrm{p} 14.1 ; \mathrm{q} 32)$ envolvendo os genes IGH e FOXP1 foram descritas nos LCCB da zona marginal, entretanto ainda não constituindo marcadores específicos para este grupo [19]. Outras translocações como $t(11 ; 18)(q 21 ; q 21)$ e $t(1 ; 14)(p 22 ; q 32)$ são descritas [38].

A hipermutação somática dos genes de cadeia leve e pesada, e a inativação dos genes supressores tumorais como p15 e p16 (10-30\%) foram descritas nos casos de LCCB centro-folicular [90,106,107]. As translocações cromossômicas, t(14;18)(q32;q21), envolvendo gene $B C L 2$, anteriormente somente descritas para os linfomas nodais, foram evidenciadas pela técnica de FISH em $41 \%$ dos casos de LCCB centro-folicular. Assim como translocação afetando BCL6, t(3;14)(q27;q32), também descrita com pequena freqüência $(7 \%)$ na série de 27 casos de LCCB centro-folicular no mesmo estudo [108]. 
Nos LCCBGC tipo perna a translocação $(14 ; 18)$ não foi observada, entretanto, a forte expressão do bcl-2 evidenciada freqüentemente pode resultar da amplificação do gene de bcl-2. A inativação dos genes supressores tumorais p15 (11\%) e p16 (44\%) e translocações envolvendo myc, bcl-6 e genes IgH foram descritas [19]. 
MÉTODOS 


\section{MÉTODOS}

\subsection{CASUÍSTICA}

A casuística deste trabalho constituiu-se de fragmentos de lesões cutâneas fixados em formalina e incluídos em parafina provenientes de 31 casos portadores de processos linfoproliferativos cutâneos de células B, acompanhados no Ambulatório de Oncologia Cutânea da Divisão de Dermatologia do Hospital das Clínicas da Faculdade de Medicina da Universidade de São Paulo (HCFMUSP), no período de janeiro de 1988 a dezembro de 2006.

Os casos haviam sido estudados e classificados para o trabalho de dissertação de mestrado ("Processos linfoproliferativos de células B: a difícil distinção entre linfomas e pseudolinfomas" - USP, 2004), através de estudo histológico e imunoistoquímico como: linfomas cutâneos de célula $B$, pseudolinfomas de célula B e inconclusivos. (Tabela 1). Informações demográficas, clínicas, evolutivas, histológicas e imunoistoquímicas referentes a cada caso encontram-se em anexos (ANEXO C e ANEXO D). 
Tabela 1 - Classificação dos 31 casos de processos linfoproliferativos cutâneos de células $B$ utilizando critérios histológicos e imunoistoquímicos

\begin{tabular}{ccc}
\hline Classificação & Freqüência & $\%$ \\
\hline Linfoma cutâneo & 14 & 45,2 \\
Pseudolinfoma & 6 & 19,3 \\
Inconclusivo & 11 & 35,5 \\
\hline Total & $\mathbf{3 1}$ & $\mathbf{1 0 0 , 0}$ \\
\hline
\end{tabular}

\subsection{MÉTODOS}

\subsubsection{AVALIAÇÃO DA CLONALIDADE}

O estudo da clonalidade foi realizado por meio da pesquisa do rearranjo dos genes da cadeia pesada e da cadeia leve de imunoglobulina utilizando-se método de PCR (reação em cadeia de polimerase), de acordo com protocolos descritos abaixo (ANEXO B).

\subsubsection{Extração do DNA através do método crude lysate.}

Cinco cortes de 5-10 $\mu \mathrm{m}$ foram realizados em micrótomo com lâmina virgem do material proveniente de biópsia cutânea (fragmentos de pele fixados em formalina e emblocados em parafina) dos doentes a serem 
estudados. O material foi armazenado em microtubos $(1.5 \mathrm{ml})$ de Eppendorf estéreis e livres de DNA. Os cortes foram submetidos ao protocolo para desparafinação conforme descrito a seguir:

1. Centrifugação do microtubo por 10 segundos para coleta do material depositado no fundo do tubo.

2. Adição de $1 \mathrm{ml}$ de xilol ao material contido no tubo, misturando-o através da utilização do aparelho vortex por 10 segundos e incubação à temperatura ambiente por 5 a 10 minutos.

3. Centrifugação da amostra por cinco minutos para formação de pellet no fundo do microtubo de Eppendorf. Remoção cuidadosa do xilol por aspiração.

4. Repetição dos itens 2 e 3.

5. Adição de $1 \mathrm{ml}$ de álcool etílico $100 \%$ misturando vigorosamente no vortex por 10 segundos.

6. Centrifugação da amostra por cinco minutos para formação de pellet no fundo do microtubo. Remoção cuidadosa do álcool por aspiração.

7. Repetição dos itens 5 e 6.

8. Manutenção do microtubo aberto e aquecido a $37^{\circ} \mathrm{C}$ para secagem completa do material.

9. Adição de $50-150 \mu l$ de solução para lavagem contendo proteinase $\mathrm{K}$ (Sigma, UK), solução tampão para PCR (Sigma, UK), e água ultrapura livre de DNA para digestão do material, misturando a solução ao material para que este fique completamente imerso. 
Subseqüente, incubação do material por 24 horas a $37^{\circ} \mathrm{C}$ e desativação da enzima proteinase $\mathrm{K}$ através do aquecimento a $95^{\circ} \mathrm{C}$ por 15 minutos.

Após a realização do protocolo de extração do $D N A$, o produto era utilizado imediatamente para amplificação por $P C R$ ou armazenado a temperatura de menos $20^{\circ} \mathrm{C}$.

\subsubsection{Ampliação do DNA por $P C R$.}

Para cada reação com o volume total de $25 \mu$ foi utilizado $23 \mu \mathrm{l}$ de solução mastermix adicionando-se $2 \mu$ de DNA. O mastermix foi composto por solução tampão II (Applied Biosystems, UK), $200 \mu \mathrm{M}$ de cada dNTP (Promega, UK), $1.5 \mathrm{mM}$ de $\mathrm{MgCl}_{2}, 1 \mathrm{U}$ da enzima Amplitaq GOLD (Taq polimerase, Applied Biosystems, UK), água ultrapura (Sigm, UK) e 5 pmol de cada primer (MWG,USA) específicos para cada reação (Quadro 3).

O programa mais utilizado pelo termociclador, aparelho de $P C R$ (Mastercycler Gradient, CA), neste trabalho foi o BIOMED 2 (7 minutos a $95{ }^{\circ} \mathrm{C}$, seguido por 40 ciclos de 45 segundos a $93^{\circ} \mathrm{C}, 45$ segundos a $60{ }^{\circ} \mathrm{C}$, 1 minuto e 30 segundos a $72{ }^{\circ} \mathrm{C}$, e finalizando com 5 minutos a $72{ }^{\circ} \mathrm{C}$ ). $\mathrm{O}$ programa IGTCR foi aplicado ao protocolo IgH FR3 clássico (Nizet). Para cada reação foi usada água pura livre de DNA como controle negativo e linfoma não Hodgkin nodal como controle positivo. 
Quadro 3 - Detalhes dos primers utilizados nos protocolos para amplificação do DNA e pesquisa da clonalidade

\begin{tabular}{|c|c|}
\hline PROTOCOLO & PRIMER - SEQUENCIA (5’ $\left.\rightarrow 3^{\prime}\right)$ \\
\hline IgH FR2 Biomed & $\begin{array}{ll}\text { VH1-FR2 } & \text { CTGGGTGCGACAGGCCCCTGGACAA } \\
\text { VH2-FR2 } & \text { TGGATCCGTCAGCCCCCAGGGAAGG } \\
\text { VH3-FR2 } & \text { GGTCCGCCAGGCTCCAGGGAA } \\
\text { VH4-FR2 } & \text { TGGATCCGCCAGCCCCCAGGGAAGG } \\
\text { VH5-FR2 } & \text { GGGTGCGCCAGATGCCCGGGAAAGG } \\
\text { VH6-FR2 } & \text { TGGATCAGGCAGTCCCCATCGAGAG } \\
\text { VH7-FR2 } & \text { TTGGGTGCGACAGGCCCCTGGACAA } \\
\text { JH } & \text { CCAGTGGCAGAGGAGTCCATTC }\end{array}$ \\
\hline IgH FR3 Biomed & $\begin{array}{ll}\text { VH1-FR3 } & \text { TGGAGCTGAGCAGCCTGAGATCTGA } \\
\text { VH2-FR3 } & \text { CAATGACCAACATGGACCCTGTGGA } \\
\text { VH3-FR3 } & \text { TCTGCAAATGAACAGCCTGAGAGCC } \\
\text { VH4-FR3 } & \text { GAGCTCTGTGACCGCCGCGGACACG } \\
\text { VH5-FR3 } & \text { CAGCACCGCCTACCTGCAGTGGAGC } \\
\text { VH6-FR3 } & \text { GTTCTCCCTGCAGCTGAACTCTGTG } \\
\text { VH7-FR3 } & \text { CAGCACGGCATATCTGCAGATCAG } \\
\text { JH } & \text { CCAGTGGCAGAGGAGTCCATTC }\end{array}$ \\
\hline IgH FR3 Nizet & $\begin{array}{ll}\text { FR3 } & \text { CCGAGGACACGGCCGTGTATTACTG } \\
\mathrm{JH} & \text { AACTGCTGAGGAGACGGTGACC }\end{array}$ \\
\hline IgL kappa & $\begin{array}{ll}V_{\kappa F R 3-1} & \text { TTCAG(C/T)GGCAGTGG(A/G)TCTGG } \\
V_{\kappa} \text { FR3 -2 } & \text { TTCAGTGGCAGTGGG(G/T)CAGG } \\
\mathrm{J}_{\kappa} 1 & \text { TTTGAT(A/T/C)TCCACCTTGGTCCC } \\
\mathrm{J}_{\kappa 2} & \text { TTTAATCTCCAGTCGTGTCCC }\end{array}$ \\
\hline TCR gamma A e B & $\begin{array}{ll}V_{\gamma}(\mathrm{A}) & \text { GGAAGGCCCCACGCRTCTT } \\
V_{\gamma}(\mathrm{A}) & \text { AGCATGGGTAAGACAAGCAA } \\
V_{\gamma}(\mathrm{B}) & \text { CGGCACTGTCAGAAAGGAATC } \\
V_{\gamma}(\mathrm{B}) & \text { CTTCCACTTCCACTTTGAAA } \\
J_{\gamma} & \text { CGAGTATCATTGAAGCGGACCATT } \\
J_{\gamma} & \text { GAGAAACCGTCACCTTGTTGTG }\end{array}$ \\
\hline
\end{tabular}

FONTE: van Dongen JJ et al. Leukemia 2003 Dec;17(12):2257-317 e Diss TC e col Mol Pathol. 2002 Apr;55(2):98-101.

Para controle da qualidade do DNA em cada amostra foram utilizados iniciadores (primers) para amplificação de housekeeping genes de 100, 200, 300 e 400 pares de base (pb) (Figura 4). O programa utilizado no aparelho de PCR foi o BIOMED2. Considerou-se DNA de boa qualidade quando se demonstrou presença de seqüência de nucleotídeos com 100, 200 e 300pb ou 100, 200, 300 e 400pb; DNA de moderada qualidade aquele com seqüência com 100 e 200pb; e de baixa qualidade aquele com seqüência de somente 100pb. 


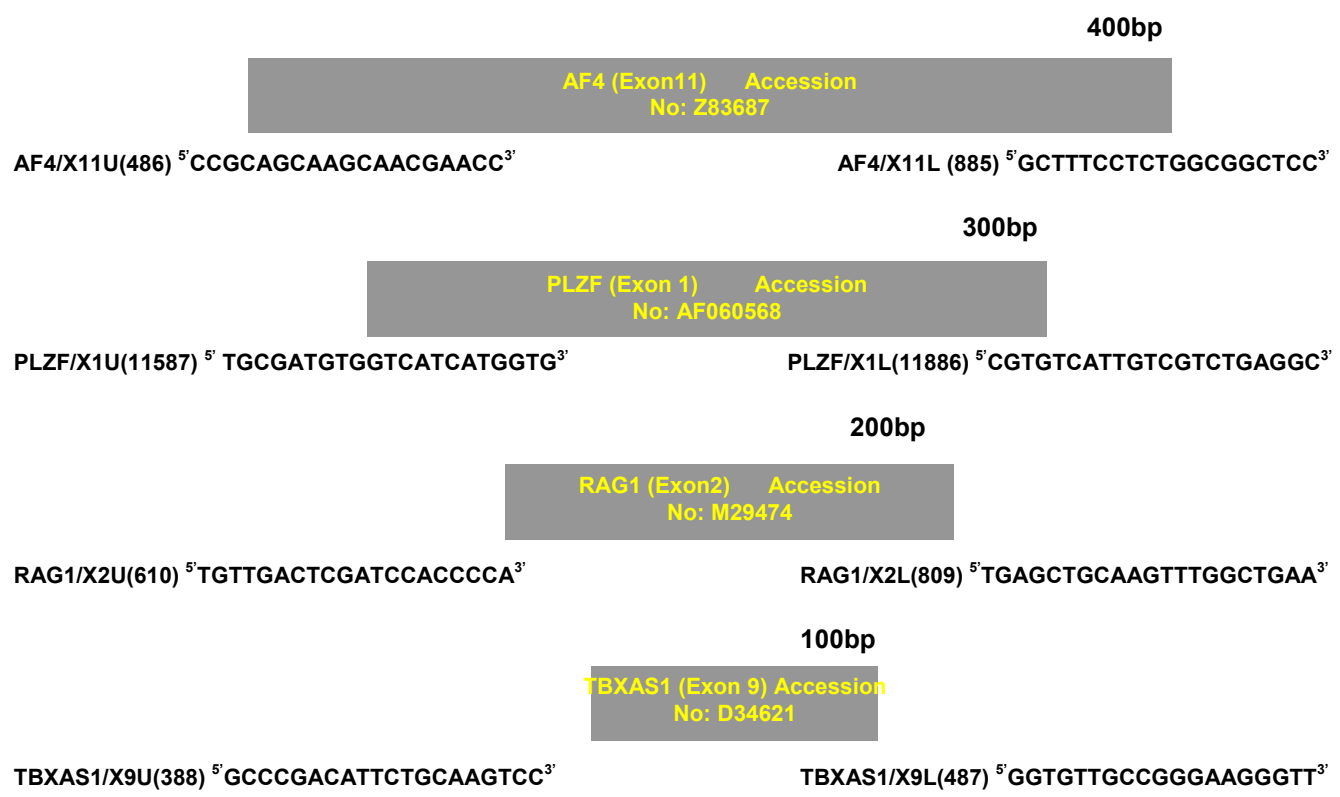

Figura 4. Iniciadores (primers) para amplificação de housekeeping genes de $100,200,300$ e 400 pares de base

Para a pesquisa do rearranjo dos genes da cadeia pesada de imunoglobulina foram utilizados os seguintes protocolos:

- Protocolo IgH FR2 Biomed: os primers utilizados foram BIOMED FR2/JH reverso, o ciclo do programa BIOMED2, e o tamanho do produto pesquisado em pares de base foi de 250 - 295.

- Protocolo IgH FR3 Biomed: os primers utilizados foram BIOMED FR3/JH reverso, o ciclo do programa BIOMED2, e o tamanho do produto pesquisado em pares de base foi de $100-170$. 
- Protocolo IgH FR3 clássico (Nizet): os primers utilizados foram FR3 clássico/JH clássico reverso, o ciclo do programa IGTCR, e o tamanho do produto pesquisado em pares de base foi de $80-120$.

Para a pesquisa do rearranjo dos genes da cadeia leve kappa de imunoglobulina foi utilizado o seguinte protocolo:

- Protocolo IgL Kappa A e B: os primers utilizados foram IgKA e $\operatorname{lgKB} / \mathrm{JH}$, o ciclo do programa BIOMED2, e o tamanho do produto pesquisado em pares de base foi 130-150.

Para a exclusão de processos linfoproliferativos monoclonais de células T (LCCT/NK) foi pesquisado o rearranjo dos genes do receptor de célula T (TCR) através do seguinte protocolo:

- Pesquisa do rearranjo do receptor de células T (gamma A e B): os primers utilizados foram Biomed2 TCR gamma-A e Biomed2 TCR gamma-B/JH, o programa utilizado foi BIOMED2, e o tamanho do produto pesquisado em pares de base foi A 145-255; e B 80-220. 


\subsubsection{Corrida eletroforética e revelação da imagem}

Após a ampliação do DNA pelo aparelho de $P C R$, foram realizadas corridas eletroforéticas e revelação da imagem. Inicialmente adicionado $8 \mu$ l do produto do PCR a $2 \mu$ l de blue loading buffer $(4 \%$ sucrose, TBE bromofenol blue e xylene cyanol, total $10 \mu \mathrm{l}$ ) e depositados por pipeta em gel de poliacrilamida a 6 ou $8 \%$ (água ionizada, TBE, acrilogel 5, persulfato de amônia e TEMED). Realizada corrida eletroforética a $200 \mathrm{~V}$ por 40 minutos. A seguir, as placas de poliacrilamida receberam banho de brometo de etídio por 5 minutos e revelação do padrão de bandas em imagens adquiridas por iluminação em luz ultravioleta. $O$ registro da imagem foi efetuado em arquivo digital, assim como fotografia Polaroid, obtida pelo sistema BioRad Gel Doc 2000.

As imagens obtidas foram analisadas e cada caso foi classificado como:

- Monoclonal: visualização de banda estreita e brilhante bem definida,

- Policlonal: visualização de banda alargada e pouco definida semelhante a esfregaço.

- Não definido: ausência de banda ou presença de imagem sem definição (Figura 5). 


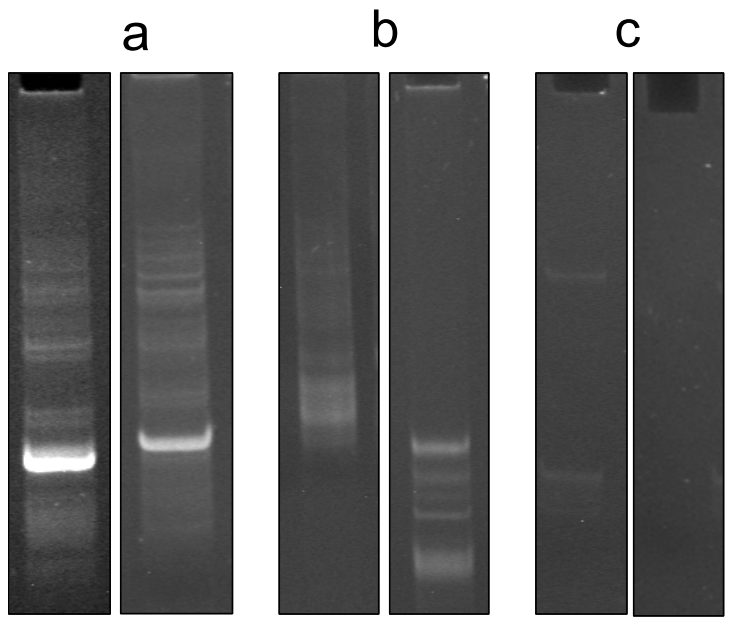

Figura 5. Imagem em gel de poliacrilamida. (a) Monoclonalidade: presença de banda brilhante bem definida; (b) Policlonalidade: presença de banda pouco definida ou imagem semelhante a um esfregaço e; (c) Não definida: ausência de imagem ou imagem sem definição

Concluiu-se por processo linfoproliferativo de células B monoclonal, quando ao menos um dos protocolos para pesquisa do rearranjo das cadeias IgH ou IgL demonstrou monoclonalidade.

As reações foram repetidas isoladamente ou duplicadas (duas reações idênticas utilizando-se duas amostras independentes de DNA do mesmo caso) quando houve dúvida quanto à imagem e/ou para confirmação dos resultados. 
RESULTADOS 


\section{RESULTADOS}

\subsection{CONTROLE DA PRESENÇA E DA QUALIDADE DO DNA DA CASUÍSTICA}

Os resultados referentes à presença e qualidade do DNA dos 31 casos inicialmente avaliados para este estudo encontram-se demonstrados na Tabela 2. Dois casos (casos 9 e 28) não apresentaram DNA viável e portanto foram excluídos. Observou-se que apenas seis casos (19\%) apresentavam DNA de boa qualidade (Figura 6).

Tabela 2 - Avaliação da presença e qualidade do DNA através da amplificação de housekeeping genes de 100, 200, 300 e 400 pares de base $(\mathrm{pb})$ nos 31 casos de processos linfoproliferativos de células $B$

\begin{tabular}{cc}
\hline PRESENÇA E QUALIDADE DO DNA AMOSTRA & TOTAL \\
\hline Ausência de DNA & 2 \\
$100 \mathrm{pb}$ & 8 \\
100 e $200 \mathrm{pb}$ & 15 \\
100,200 e $300 \mathrm{pb}$ & 6 \\
$100,200,300$ e $400 \mathrm{bp}$ & 0 \\
\hline
\end{tabular}




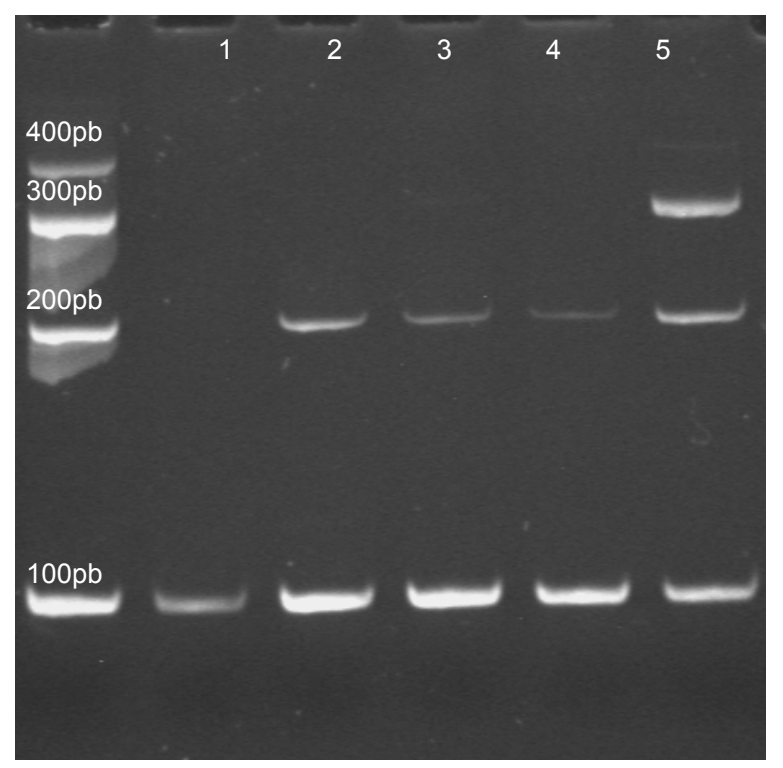

Figura 6. Reação para avaliação da qualidade do DNA através da amplificação de housekeeping genes de 100, 200, 300 e 400 pb. Na primeira coluna a esquerda observa-se controle positivo com a presença das quatro bandas. Colunas de 1 a 5 demonstram casos evidenciando a presença de bandas de 100 pb (caso 1), 100 - 200 pb (casos 2, 3 e 4), e 100, 200 - 300 $\mathrm{pb}$ (caso 5)

\subsection{PESQUISA DA CLONALIDADE DO REARRANJO DOS GENES DE CADEIA PESADA DE IMUNOGLOBULINA (IGH FR2 BIOMED, IGH FR3 BIOMED, IGH FR3 NIZET)}

Pode-se observar na Tabela 3 os resultados descritivos da pesquisa de clonalidade através da detecção do rearranjo dos genes da cadeia pesada de imunoglobulina para os três protocolos aplicados neste estudo. 
Tabela 3 - Resultados descritivos da pesquisa da clonalidade do rearranjo dos genes de cadeia pesada $(\mathrm{lgH})$ nos 29 casos de processos linfoproliferativos de células B

\begin{tabular}{|c|c|c|c|c|}
\hline No & $H E+I I Q$ & IgH FR3 Nizet & IgH FR3 BIOMED & IgH FR2 Biomed \\
\hline 1 & LCCB & não definido & não definido & não definido \\
\hline 3 & LCCB & não definido & não definido & não definido \\
\hline 7 & LCCB & monoclonal & não definido & não definido \\
\hline 10 & LCCB & monoclonal & não definido & não definido \\
\hline 12 & LCCB & policlonal & policlonal & não definido \\
\hline 14 & LCCB & monoclonal & não definido & não definido \\
\hline 15 & LCCB & não definido & não definido & não definido \\
\hline 16 & LCCB & não definido & não definido & não definido \\
\hline 20 & $\mathrm{LCCB}$ & policlonal & não definido & não definido \\
\hline 23 & LCCB & policlonal & não definido & não definido \\
\hline 26 & LCCB & policlonal & não definido & não definido \\
\hline 29 & LCCB & policlonal & não definido & não definido \\
\hline 30 & LCCB & policlonal & não definido & não definido \\
\hline 5 & $P L$ & não definido & não definido & não definido \\
\hline 8 & PL & não definido & não definido & não definido \\
\hline 17 & $P L$ & policlonal & não definido & não definido \\
\hline 19 & PL & policlonal & não definido & não definido \\
\hline 21 & $P L$ & policlonal & policlonal & não definido \\
\hline 31 & $P L$ & policlonal & não definido & não definido \\
\hline 2 & INC & monoclonal & não definido & não definido \\
\hline 4 & INC & policlonal & não definido & não definido \\
\hline 6 & INC & policlonal & não definido & não definido \\
\hline 11 & INC & não definido & não definido & não definido \\
\hline 13 & INC & policlonal & não definido & não definido \\
\hline 18 & INC & policlonal & não definido & não definido \\
\hline 22 & INC & policlonal & não definido & não definido \\
\hline 24 & INC & monoclonal & monoclonal & não definido \\
\hline 25 & INC & policlonal & não definido & não definido \\
\hline 27 & INC & não definido & não definido & não definido \\
\hline
\end{tabular}


Nas Tabelas 4, 5 e 6 observa-se que a monoclonalidade foi demonstrada em apenas $23 \%$ dos casos classificados como LCCB pelo protocolo IgH FR3 Nizet, e em $20 \%$ dos casos classificados como inconclusivos (um deles por lgH Nizet e lgH FR3 Biomed e o outro somente por IgH Nizet).

Tabela 4 - Resultados da pesquisa da clonalidade do rearranjo dos genes de cadeia pesada $(\lg \mathrm{H})$ nos 13 casos definidos como linfomas cutâneos segundo critérios histológicos e imunoistoquímicos

\begin{tabular}{cccc}
\hline LCCB & IgH FR3 Nizet & IgH FR3 Biomed & IgH FR2 Biomed \\
\hline MONOCLONAL & $3(23 \%)$ & $0(-)$ & $0(-)$ \\
POLICLONAL & $6(46 \%)$ & $1(8 \%)$ & $0(-)$ \\
NÃO DEFINIDO & $4(31 \%)$ & $12(92 \%)$ & $0(100 \%)$ \\
\hline TOTAL & $13(100 \%)$ & $13(100 \%)$ & $13(100 \%)$ \\
\hline
\end{tabular}

Tabela 5 - Resultados da pesquisa da clonalidade do rearranjo dos genes de cadeia pesada $(\mathrm{lgH})$ nos seis casos definidos como pseudolinfomas de acordo com critérios histológicos e imunoistoquímicos

\begin{tabular}{cccc}
\hline PLB & IgH FR3 Nizet & IgH FR3 Biomed & IgH FR2 Biomed \\
\hline MONOCLONAL & $0(-)$ & $0(-)$ & $0(-)$ \\
POLICLONAL & $4(67 \%)$ & $1(17 \%)$ & $0(-)$ \\
NÃO DEFINIDO & $2(33 \%)$ & $5(83 \%)$ & $6(100 \%)$ \\
\hline TOTAL & $6(100 \%)$ & $6(100 \%)$ & $6(100 \%)$ \\
\hline
\end{tabular}

Tabela 6 - Resultados da pesquisa da clonalidade do rearranjo dos genes de cadeia pesada $(\lg \mathrm{H})$ nos dez casos considerados inconclusivos de acordo com critérios histológicos e imunoistoquímicos

\begin{tabular}{cccc}
\hline INCONCLUSIVOS & IgH F3 Nizet & IgH F3 Biomed & IgH F2 Biomed \\
\hline MONOCLONAL & $2(20 \%)$ & $1(10 \%)$ & $0(-)$ \\
POLICLONAL & $6(60 \%)$ & $0(-)$ & $0(-)$ \\
NÃO DEFINIDO & $2(20 \%)$ & $9(90 \%)$ & $10(100 \%)$ \\
\hline TOTAL & $10(100 \%)$ & $10(100 \%)$ & $10(100 \%)$ \\
\hline
\end{tabular}




\subsection{PESQUISA DA CLONALIDADE DO REARRANJO DOS GENES DE CADEIA LEVE DE IMUNOGLOBULINA (IGL KAPPA)}

A Tabela 7 demonstra os resultados descritivos da pesquisa da clonalidade do rearranjo dos genes da cadeia leve kappa de imunoglobulina.

Tabela 7 - Resultados descritivos da pesquisa da clonalidade do rearranjo dos genes de cadeia leve ( $\mathrm{lgL}$ ) nos 29 casos de processos linfoproliferativos de células $B$

\begin{tabular}{|c|c|c|}
\hline NO & HE+IIQ & IgL KAPPA \\
\hline 1 & LCCB & monoclonal \\
\hline 3 & LCCB & não definido \\
\hline 7 & LCCB & monoclonal \\
\hline 10 & LCCB & monoclonal \\
\hline 12 & LCCB & monoclonal \\
\hline 14 & LCCB & monoclonal \\
\hline 15 & LCCB & não definido \\
\hline 16 & LCCB & não definido \\
\hline 20 & LCCB & monoclonal \\
\hline 23 & LCCB & policlonal \\
\hline 26 & LCCB & policlonal \\
\hline 29 & LCCB & monoclonal \\
\hline 30 & LCCB & monoclonal \\
\hline 5 & $\mathrm{PL}$ & não definido \\
\hline 8 & $\mathrm{PL}$ & não definido \\
\hline 17 & $\mathrm{PL}$ & policlonal \\
\hline 19 & $\mathrm{PL}$ & não definido \\
\hline 21 & $\mathrm{PL}$ & policlonal \\
\hline 31 & $\mathrm{PL}$ & policlonal \\
\hline 2 & INC & policlonal \\
\hline 4 & INC & policlonal \\
\hline 6 & INC & policlonal \\
\hline 11 & INC & não definido \\
\hline 13 & INC & policlonal \\
\hline 18 & INC & não definido \\
\hline 22 & INC & policlonal \\
\hline 24 & INC & monoclonal \\
\hline 25 & INC & policlonal \\
\hline
\end{tabular}


Nas Tabelas 8, 9 e 10 monoclonalidade foi demonstrada em apenas $61,5 \%$ dos casos classificados como LCCB pelo protocolo IgL Kappa, e em $10 \%$ dos casos classificados como inconclusivos.

Tabela 8 - Resultados da pesquisa da clonalidade do rearranjo dos genes de cadeia leve ( $\operatorname{lgL}$ ) nos 13 casos definidos como linfomas cutâneos segundo critérios histológicos e imunoistoquímicos

\begin{tabular}{cc}
\hline LCCB & IgL Kappa \\
\hline MONOCLONAL & $8(61,5 \%)$ \\
POLICLONAL & $2(15,4 \%)$ \\
NÃO DEFINIDO & $3(23,1 \%)$ \\
\hline TOTAL & $13(100,0 \%)$ \\
\hline
\end{tabular}

Tabela 9 - Resultados da pesquisa da clonalidade do rearranjo dos genes de cadeia leve ( $\mathrm{g} \mathrm{L})$ nos seis casos definidos como pseudolinfomas de acordo com critérios histológicos e imunoistoquímicos

\begin{tabular}{cc}
\hline PLB & IgL Kappa \\
\hline MONOCLONAL & $0(-)$ \\
POLICLONAL & $3(50 \%)$ \\
NÃO DEFINIDO & $3(50 \%)$ \\
\hline TOTAL & $6(100 \%)$ \\
\hline
\end{tabular}

Tabela 10 -Resultados da pesquisa da clonalidade do rearranjo dos genes de cadeia leve ( $\lg \mathrm{L})$ nos dez casos considerados inconclusivos de acordo com critérios histológicos e imunoistoquímicos

\begin{tabular}{cc}
\hline INCONCLUSIVOS & IgL Kappa \\
\hline MONOCLONAL & $1(10 \%)$ \\
POLICLONAL & $6(60 \%)$ \\
NÃO DEFINIDO & $3(30 \%)$ \\
\hline TOTAL & $10(100 \%)$ \\
\hline
\end{tabular}




\subsection{PESQUISA DA CLONALIDADE DO REARRANJO DOS GENES DO RECEPTOR DE CÉLULAS T (TCR)}

A pesquisa de clonalidade para linfócitos $T(T C R)$ foi realizada em todos os casos com DNA viável, demonstrando policlonalidade em 18 deles e sem definição da clonalidade em 12 casos (ANEXO C).

\subsection{CONTRIBUIÇÃO DO ESTUDO DA CLONALIDADE NA DEFINIÇÃO DIAGNÓSTICA DOS PROCESSOS LINFOPROLIFERATIVOS DE CÉLULAS B}

A Tabela 11 evidencia a contribuição no diagnóstico dos LCCB demonstrando monoclonalidade em $20 \%$ dos casos inconclusivos.

Tabela 11 - Valor da pesquisa de clonalidade na conclusão diagnóstica dos 29 casos de processos linfoproliferativos de células B

\begin{tabular}{ccccc}
\hline DIAG. BM ${ }^{+}$ & Ponoclonal & Noliclonal & Não-definido & $\begin{array}{c}\text { Total } \\
\text { HE-IIQ }\end{array}$ \\
\hline Linfoma cutâneo & $8^{* *}(80 \%)$ & $2(16,7 \%)$ & $3(42,8 \%)$ & 13 \\
Pseudolinfoma & - & $4^{* *}(33,3 \%)$ & $2(28,6 \%)$ & $\mathbf{6}$ \\
Inconclusivo & $2^{*}(20 \%)$ & $6(50 \%)$ & $2(28,6 \%)$ & 10 \\
\hline Total BM & $\mathbf{1 0}$ & $\mathbf{1 2}$ & $\mathbf{7}$ & $\mathbf{2 9}$ \\
\hline
\end{tabular}

* casos onde a biologia molecular acrescentou dados para o diagnóstico final;

** casos onde a biologia molecular corroborou o diagnóstico referente ao HE-IIQ

+ DIAG.BM: diagnóstico referente à pesquisa da clonalidade por meio da biologia molecular;

\#DIAG. HE-IIQ: diagnóstico referente a características do HE e imunoistoquímica 


\subsection{DETECÇAO DA MONOCLONALIDADE NOS LCCB CONFORME CLASSIFICAÇAO DA WHO-EORTC}

Em relação à pesquisa da clonalidade nos LCCB (segundo a classificação WHO-EORTC), embora o número de casos seja relativamente pequeno, pôde-se observar monoclonalidade em sete casos dentre 10 classificados como LCCB centro-folicular e um caso entre dois classificados como LCCB da zona marginal. A pesquisa da clonalidade não foi definida, utilizando todos os protocolos, no único caso de LCCB difuso de grandes células, tipo perna (Tabelas 12, 13 e 14).

Tabela 12 - Resultados da pesquisa da clonalidade nos casos classificados de acordo com critérios histológicos e imunoistoquímicos em LCCB centro-folicular segundo WHO-EORTC

\begin{tabular}{lllll}
\hline LCCB Centro-folicular & IgH FR3 Nizet & IgH FR3 Biomed & IgH FR2 Biomed & IgL Kappa \\
\hline MONOCLONAL & $2(20 \%)$ & $0(-)$ & $0(-)$ & $7(70 \%)$ \\
POLICLONAL & $5(50 \%)$ & $1(10 \%)$ & $0(-)$ & $1(10 \%)$ \\
NÃO DEFINIDO & $3(30 \%)$ & $9(90 \%)$ & $10(100 \%)$ & $2(20 \%)$ \\
\hline TOTAL & $10(100 \%)$ & $10(100 \%)$ & $10(100 \%)$ & $10(100 \%)$ \\
\hline
\end{tabular}

Tabela 13 -Resultados da pesquisa da clonalidade nos casos classificados de acordo com critérios histológicos e imunoistoquímicos em LCCB zona marginal segundo WHO-EORTC

\begin{tabular}{lllll}
\hline LCCB da Zona Marginal & IgH FR3 Nizet & IgH FR3 Biomed & IgH FR2 Biomed & IgL Kappa \\
\hline MONOCLONAL & $1(50 \%)$ & $0(-)$ & $0(-)$ & $1(50 \%)$ \\
POLICLONAL & $1(50 \%)$ & $0(-)$ & $0(-)$ & $1(50 \%)$ \\
NÃO DEFINIDO & $0(-)$ & $2(100 \%)$ & $2(100 \%)$ & $0(-)$ \\
\hline TOTAL & $2(100 \%)$ & $2(100 \%)$ & $2(100 \%)$ & $2(100 \%)$ \\
\hline
\end{tabular}


Tabela 14 -Resultados da pesquisa da clonalidade no caso classificado de acordo com critérios histológicos e imunoistoquímicos em LCCB difuso de grandes células, tipo perna segundo WHO-EORTC

\begin{tabular}{lllll}
\hline LDGC, tipo perna & IgH FR3 Nizet & IgH FR3 Biomed & IgH FR2 Biomed & IgL Kappa \\
\hline MONOCLONAL & $0(-)$ & $0(-)$ & $0(-)$ & $0(-)$ \\
POLICLONAL & $0(-)$ & $0(-)$ & $0(-)$ & $0(-)$ \\
NÃO DEFINIDO & $1(100 \%)$ & $1(100 \%)$ & $1(100 \%)$ & $1(100 \%)$ \\
\hline TOTAL & $1(100 \%)$ & $1(100 \%)$ & $1(100 \%)$ & $1(100 \%)$ \\
\hline
\end{tabular}


DISCUSSÃO 


\section{DISCUSSÃO}

O diagnóstico diferencial entre LCCB e PLB é importante para o tratamento e seguimento adequado destes processos. A diferenciação entre tais entidades é sabidamente complexa e desafiadora, não existindo até o presente método específico ou considerado "gold-standard" [3,40]. A abordagem diagnóstica é multidisciplinar e envolve critérios clínicos, histológicos, imunoistoquímicos e evolutivos [3]. Técnicas de biologia molecular vêm sendo empregadas freqüentemente na Europa e nos EUA como métodos diagnósticos auxiliares. No Brasil não são técnicas de uso rotineiro, assim como não há estudos demonstrando a experiência do método para o diagnóstico dos LCCB.

A classificação dos linfomas cutâneos vem sendo discutida nos últimos anos. Após uma década de controvérsia entre WHO e EORTC, em 2005, as instituições elaboraram uma nova classificação consensual WHOEORTC, que deverá facilitar, com a maior uniformidade de informações, a abordagem dos pacientes $[19,38]$. 
Estudos recentes sugerem que os pseudolinfomas e linfomas cutâneos de baixo grau possam pertencer a um espectro de processos linfoproliferativos de células $\mathrm{B}$, onde o primeiro estágio da morbidade representaria um processo inflamatório reacional (pseudolinfoma) que evoluiria até um estado neoplásico maligno franco (linfoma). Tal fato poderia explicar a grande dificuldade no diagnóstico dos linfomas cutâneos nos estágios iniciais e intermediários do espectro $[40,73]$. Recentemente, avanços da biologia molecular na detecção da clonalidade dos infiltrados linfocitários B, assim como estudos sobre translocações cromossômicas e desenvolvimento de novos marcadores imunoistoquímicos, vêm contribuindo para a elucidação destes diversos estágios evolutivos no contexto da "teoria espectral da patogênese dos processos linfoproliferativos cutâneos" [3,56,61].

Embora a importância da avaliação histológica e imunoistoquímica seja indiscutível para a determinação dos LCCB, muitos casos clinicamente sugestivos de linfomas permanecem sem diagnóstico ou são classificados como pseudolinfomas, apesar do uso de vários marcadores imunoistoquímicos $[47,109]$. Estudo realizado anteriormente, com casuística deste trabalho, demonstrou que a avaliação imunoistoquímica contribuiu para o diagnóstico de LCCB em $12 \%$ de casos considerados à histopatologia, inconclusivos ou pseudolinfomas [32]. Portanto, novos estudos são necessários no campo da imunoistoquímica e biologia molecular. Novos marcadores imunoistoquímicos estão sendo desenvolvidos 
como IRTA1 (marcador para linfomas da zona marginal extranodal) e o MUM1 (marcador para LCCB difuso de grandes células). A técnica de tissue microarrays está sendo usada como facilitadora no estudo de novos marcadores visando o aumento da precisão diagnóstica [3,53,61,62].

A pesquisa de clonalidade, assim como grande parte dos estudos que utilizam métodos de biologia molecular, é realizada comumente em material a fresco e/ou congelado. O armazenamento de material a fresco, principalmente derivado de biópsias cutâneas, não é realidade em nosso meio. As técnicas de biologia molecular em material fixado em formalina e incluído em parafina, técnica de rotina em anatomia patológica, vêm sendo otimizadas e suas aplicações intensificadas. A preservação e fixação adequada, no entanto, é fundamental para a conservação do material genético.

Este estudo avaliou a contribuição diagnóstica da pesquisa da clonalidade, utilizando técnicas de biologia molecular em material de arquivo, para a análise do rearranjo dos genes das cadeias leve e pesada de imunoglobulinas nos processos linfoproliferativos de células B e suas limitações. 


\subsection{ASPECTOS DA BIOLOGIA MOLECULAR}

A biologia molecular vem assumindo papel de destaque na rotina diagnóstica das neoplasias. Nos processos linfoproliferativos, a pesquisa de clonalidade corrobora o diagnóstico de linfoma. Vários pontos merecem atenção e discussão em todo o processo de pesquisa da clonalidade, visando a determinação de protocolos mais adequados, aperfeiçoamento de técnica e aumento de sensibilidade dos métodos disponíveis.

\subsubsection{QUALIDADE DO DNA}

A qualidade do DNA presente na amostra é de extrema importância para o sucesso da pesquisa da clonalidade pelo método de PCR. O DNA é a molécula alvo, e portanto, todo o protocolo depende de sua integridade. O processo de fixação em formalina e inclusão em parafina pode fragmentar o DNA, comprometendo a pesquisa da clonalidade ou dificultando-a em casos onde se faz necessária a amplificação de seqüências mais longas de nucleotídeos [101,103].

Todas as etapas deste processo são importantes para o DNA. A permanência do material biopsiado fora da formalina leva à degradação dos ácidos nucléicos. A utilização de formalina não tamponada ou em concentrações inadequadas, assim como o longo tempo de permanência 
do material no fixador antes do processamento histológico levam a maior degradação do DNA [110].

Este fato poderia explicar a qualidade do DNA presente na amostra deste estudo (baixa a moderada), a ausência de DNA em dois casos, assim como a impossibilidade em amplificar o DNA na totalidade dos casos através do protocolo IgH FR2.

A baixa a moderada qualidade do DNA deste estudo pôde ser observada através da presença de seqüências dos housekeeping genes com apenas 100 e 200bp na maioria dos casos (23 casos). Somente seis casos apresentaram DNA nas bandas de 100, 200 e 300bp (Tabela 2). Este dado indica a necessidade de adequação dos métodos de biópsia, fixação em formalina e inclusão em parafina para a utilização de técnicas da biologia molecular. Atenção especial e maiores estudos são necessários para o desenvolvimento do melhor protocolo para as biópsias cutâneas, e processamento histológico adequado, e em adição armazenamento de tecido a fresco de modo a não comprometer a qualidade do DNA da amostra $[98,102]$. 


\subsubsection{INTERPRETAÇÃO DOS RESULTADOS}

No estudo da clonalidade é de extrema importância a interpretação adequada dos resultados. Tal interpretação apresenta dois pontos fundamentais.

O primeiro está na compreensão do resultado "policlonal". A policlonalidade deve ser interpretada com cautela. O resultado "policlonal" não afasta a possibilidade de linfoma, assim como não define o caso como pseudolinfoma [101]. A demonstração de infiltrado linfocitário policlonal em caso de LCCB - não indica necessariamente falha do método, mas pode representar a amplificação do DNA de células reacionais benignas da amostra [104]. Outra justificativa para o resultado "falso-negativo" (policlonalidade em casos francamente malignos), seria o uso de primers inadequados por escolha incorreta ou pela falta de primers suficientes que cubram a variedade de seguimentos gênicos V,DJ; ou ainda por anelamento inadequado como conseqüência da hipermutação somática dos genes [94,111]. Neste estudo, os primers foram testados e considerados específicos para a região alvo de amplificação.

O segundo ponto importante é o papel diagnóstico do resultado monoclonal. Enquanto a clonalidade de células $\mathrm{T}$ é relatada em alguns processos reativos (líquen plano, pitiríase liquenóide e líquen escleroso e atrófico), os infiltrados clonais de células B são freqüentemente 
neoplásicos $[78,111]$. Apesar da forte indicação de linfoma com o resultado "monoclonal", a necessidade da análise da clonalidade no contexto clínico, histológico, imunoistoquímico e evolutivo, como realizado neste estudo, se faz necessário (ANEXO A, Caso 10).

A microdissecção a laser, visando selecionar células potencialmente neoplásicas para extração do $D N A$, poderia ser útil no incremento da sensibilidade e especificidade diagnóstica do método, minimizando o índice de "falso-positivo" [112,113]. Contrariamente a esta idéia, podemos pressupor que a dificuldade na identificação histológica das células neoplásicas estaria sendo transposta para o processo de microdissecção.

\subsubsection{ESCOLHA CORRETA DOS PRIMERS E PROTOCOLOS}

Para a obtenção de maior sensibilidade na pesquisa da clonalidade através da técnica de $P C R$, além da importância da preservação adequada do DNA na amostra e da interpretação criteriosa dos resultados obtidos, é essencial a escolha dos primers e protocolos específicos [111].

Pesquisadores trabalham no desenho de novas "famílias" de primers que amplifiquem as seqüências alvo de nucleotídeos e evitem anelamento incorreto e amplificação de seqüências “não-alvo". Neste sentido, softwares foram desenvolvidos na busca dos melhores primers, e no desenho de novos primers para cada reação desejada. 
Os protocolos escolhidos para cada estudo são de extrema importância. Neste trabalho, provavelmente devido às características do DNA da amostra, na definição da clonalidade obtivemos resultados distintos como discutiremos a seguir.

\subsubsection{PESQUISA DA CLONALIDADE DO REARRANJO DOS GENES DE CADEIA PESADA DE IG (IGH FR2 BIOMED, IGH FR3 BIOMED, IGH FR3 NIZET)}

Ao avaliar os resultados da pesquisa do rearranjo dos genes de cadeia pesada da Ig utilizados neste estudo (IgH FR3 clássico Nizet, IgH FR3 Biomed e IgH FR2 Biomed), foi evidente a maior positividade do método FR3 clássico Nizet. Este método corroborou o diagnóstico de $23 \%$ dos LCCB (Tabela 3 e 4). O protocolo IgH FR3 Biomed não foi capaz de definir clonalidade em $90 \%$ dos casos e monoclonalidade foi evidenciada em apenas um caso (caso 24, coincidente com detecção de monoclonalidade pelo lgH FR3 Nizet). O método IgH FR2 Biomed não definiu clonalidade na totalidade dos 29 casos. Este protocolo amplifica um produto de $250-295 \mathrm{bp}$, necessitando da presença de DNA sem fragmentação. Outros autores também apontam a baixa sensibilidade deste método, IgH FR2, devido à qualidade e características do DNA de suas amostras [104]. O tamanho do produto pesquisado no IgH FR3 Nizet é de 80-120 pb, compatível com o tamanho do DNA presente na amostra, enquanto IgH FR3 Biomed e FR2 
Biomed amplificam seqüências maiores de nucleotídeos (100 -170bp e 250295bp respectivamente).

A pesquisa do rearranjo dos genes de $\operatorname{lgH}$ foi definitiva para o diagnóstico em dois casos considerados inconclusivos à histologia e imunoistoquímica. Estes casos foram reclassificados como LCCB, uma vez que apresentaram monoclonalidade ao método. A hipótese de um resultado "falso-positivo" torna-se altamente improvável frente ao contexto clínico patológico. Estes casos apresentavam lesões infiltradas, nodulares e em placas no dorso, muito sugestivas clinicamente com o diagnóstico de LCCB, habitualmente vistos nessa localização (anteriormente denominado "reticulohistiocitoma do dorso" ou linfoma de Crosti) (caso 2 e 24) [78,112].

\subsubsection{PESQUISA DA CLONALIDADE DOS GENES DE CADEIA LEVE DE IG (IGL KAPPA)}

A pesquisa do rearranjo dos genes de cadeia leve da imunoglobulina, Kappa, mostrou-se o método mais contributivo para o diagnóstico dos processos linfoproliferativos de células B. Este método corrobou o diagnóstico de LCCB, em 8 dentre 13 casos (61,5\%) previamente definidos pela histologia e imunoistoquímica.

Da totalidade de casos definidos como monoclonais (10), em cinco desses $(50 \%)$ a monoclonalidade foi evidenciada por meio da pesquisa do 
rearranjo dos genes de IgL kappa isoladamente. A pesquisa de clonalidade através dos protocolos de IgH não mostrou, nestes casos (casos 1, 12, 20, 29 e 30), bandas nítidas conclusivas. A maior sensibilidade do método IgL kappa poderia ser explicado pelo tamanho da seqüência do produto pesquisado neste protocolo (130-150pb), compatível com o DNA extraído da amostra deste estudo. Este fato pode indicar a necessidade da realização de, no mínimo, duas reações para a pesquisa da clonalidade, sempre que possível avaliando-se $\operatorname{lgH}$ e $\operatorname{lgL}[88,104]$ (vide Caso 1 inconclusivo IgH FR3 Nizet e monoclonal IgL K - ANEXO A).

\subsection{PESQUISA DA CLONALIDADE NOS LINFOMAS SEGUNDO A CLASSIFICAÇAO DA WHO-EORTC}

Em relação à pesquisa da clonalidade nos LCCB segundo a classificação WHO-EORTC, embora o número de casos seja relativamente pequeno, pôde-se observar monoclonalidade em sete casos dentre 10 classificados como LCCB centro-folicular e um caso entre dois classificados como LCCB da zona marginal.

A pesquisa da clonalidade não foi definida, por nenhum dos protocolos utilizados, no único caso de LCCB difuso de grandes células, tipo perna. Este caso não apresentava dificuldade diagnóstica por critérios clínicos, histológicos e imunoistoquímicos, reforçando a importância do diagnóstico multidisciplinar (ANEXO A, Caso 3). 
A literatura relata, nos linfomas difusos de grandes células B (não cutâneos) taxas percentuais mais baixas de sucesso na detecção de monoclonalidade por $\operatorname{lgH}(31 \%)$. Nos linfomas foliculares grau 1 ou 2 o percentual de monoclonalidade está em torno de 78\% [94]. Embora a casuística do presente estudo seja pequena, há indicação da reprodução de menor índice de sucesso nos linfomas difusos de grande célula B cutâneo conforme reportado na literatura.

\subsection{PERSPECTIVAS FUTURAS}

Após décadas de controvérsia, os LCCB foram reconhecidos e classificados de modo mais adequado pelo consenso WHO-EORTC, desta maneira estimulando novas pesquisas e maior conhecimento quanto ao diagnóstico, tratamento e prognóstico desses casos [3,62]. Os avanços recentes da imunoistoquímica, assim como da biologia molecular, têm contribuído para o aumento da precisão diagnóstica e maior conhecimento desses processos patológicos.

A formação e seguimento de uma coorte de pacientes portadores de LCCB, na Divisão de Dermatologia do HCFMUSP, têm possibilitado estudos que levem à compreensão da clínica, histologia e imunoistoquímica destes casos. Este trabalho, que dá continuidade ao estudo da avaliação histológica e imunoistoquímica nos processos linfoproliferativos de células B [32], introduz 
pela primeira vez técnicas de biologia molecular para a avaliação da clonalidade nesta coorte, demonstrando a necessidade da análise conjunta dos aspectos histológicos, imunoistoquímicos e da biologia molecular, para a maior sensibilidade diagnóstica nos processos linfoproliferativos de células B.

Perspectivas futuras incluem estudos adicionais com maior casuística referentes à pesquisa de clonalidade, assim como o uso de novos marcadores imunoistoquímicos, facilitados pela técnica de tissue microarray, e a detecção de possíveis translocações cromossômicas utilizando-se técnicas de hibridização in situ por fluorescência (FISH) [114-116]. Estes projetos devem se beneficiar da técnica de microdissecção a laser para maior seletividade das células alvo [117].

Acreditamos que tais propostas possam contribuir para o avanço na pesquisa e para o ensino dos processos linfoproliferativos cutâneos no país, culminando na melhoria da assistência aos portadores dessas enfermidades. 
CONCLUSÕES 


\section{CONCLUSÕES}

A pesquisa de clonalidade através do estudo do rearranjo dos genes de cadeia pesada demonstrou taxa de sucesso para corroborar o diagnóstico de LCCB em $23 \%$ dos casos e contribuiu para o diagnóstico em $20 \%$ dos casos inconclusivos. O protocolo IgH FR3 Nizet foi o mais contributivo dentre os utilizados para o estudo do rearranjo dos genes da cadeia pesada de lg. Em relação à pesquisa de clonalidade por meio do estudo do rearranjo dos genes de cadeia leve, o diagnóstico de LCCB foi corroborado em $61,5 \%$ e contribuiu para o diagnóstico de LCCB em $10 \%$ dos casos considerados inconclusivos. A monoclonalidade não foi definida em $38,5 \%$ dos casos previamente classificados como LCCB (através de critérios histológicos e imunoistoquímicos). Considerando-se os dados acima, pôde-se concluir que: 
1. Houve variabilidade na capacidade de detecção de monoclonalidade entre os diferentes protocolos.

2. A pesquisa de clonalidade utilizando-se o protocolo do estudo do rearranjo de cadeia leve kappa (IgLK) foi mais eficiente em relação aos protocolos de pesquisa de cadeia pesada $(\mathrm{lgH})$.

3. A utilização conjunta da pesquisa da clonalidade através do estudo do rearranjo dos genes da cadeia leve e pesada aumentou a taxa de sucesso para o diagnóstico de LCCB.

4. A análise conjunta da clonalidade no contexto clínico, morfológico e imunofenotípico na reclassificação dos casos de LCCB foi relevante. 
ANEXOS 


\section{ANEXO A}

Caso 10. Classificado como LCCB da zona marginal e resultado monoclonal
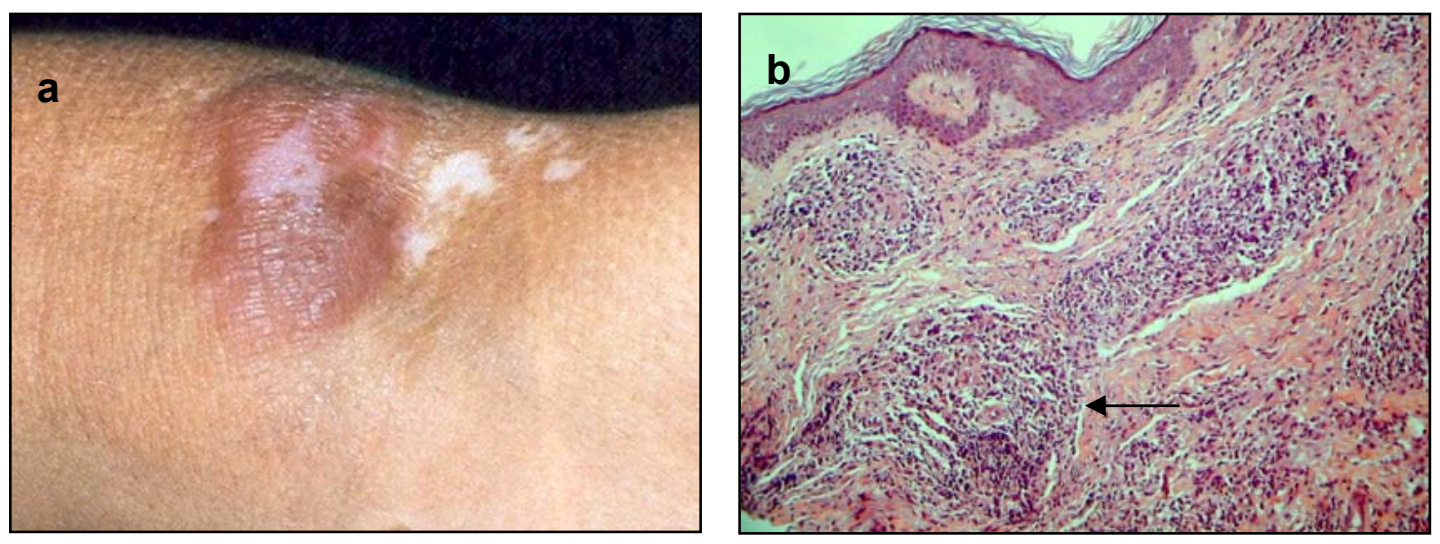

Figura 7a - Nódulo na região ante-cubital do membro superior direito; $7 \mathbf{b}$ - Consistente com LCCB da zona marginal, observado "padrão inverso" (seta), HE 100X
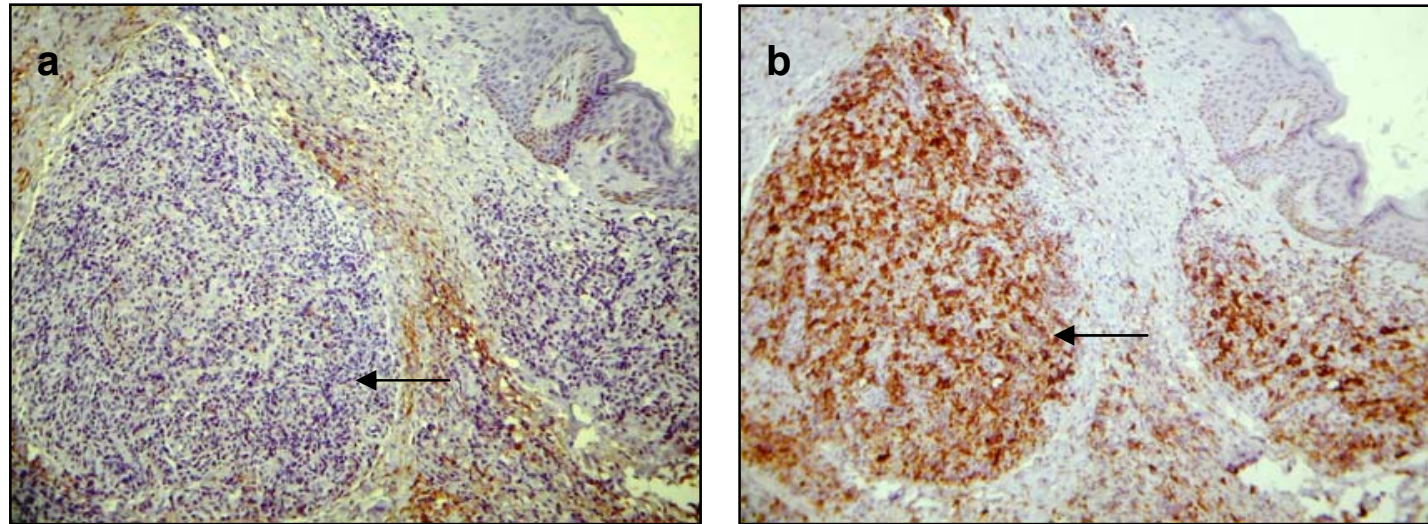

Figura 8a- Consistente com LCCB da zona marginal, CD 10 negativo nas células neoplásicas (seta), IIQ 100X; e 8b- Consistente com LCCB da zona marginal, CD 20 positivo nas células neoplásicas (seta), IIQ 100X
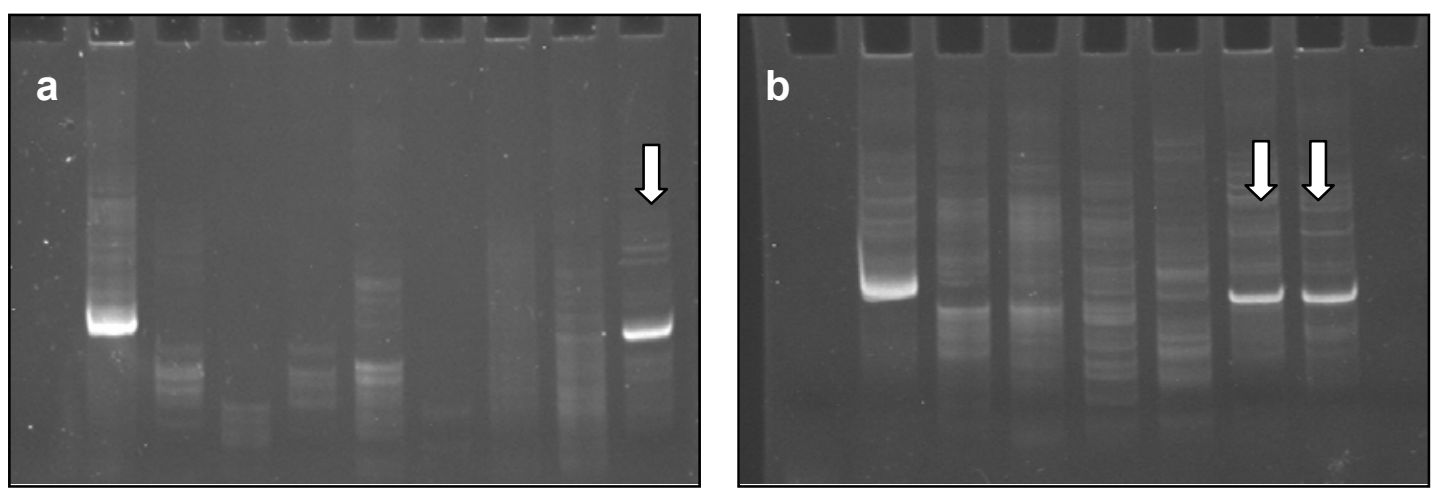

Figura 9a- Consistente com LCCB, monoclonalidade (seta) utilizando o protocolo IgH FR3 Nizet, e 9b- Consistente com LCCB, monoclonalidade (seta) utilizando o protocolo IgH FR3 Nizet duplicado para confirmar resultado 
Caso 16. Classificado como LCCB centro-folicular e clonalidade não definida
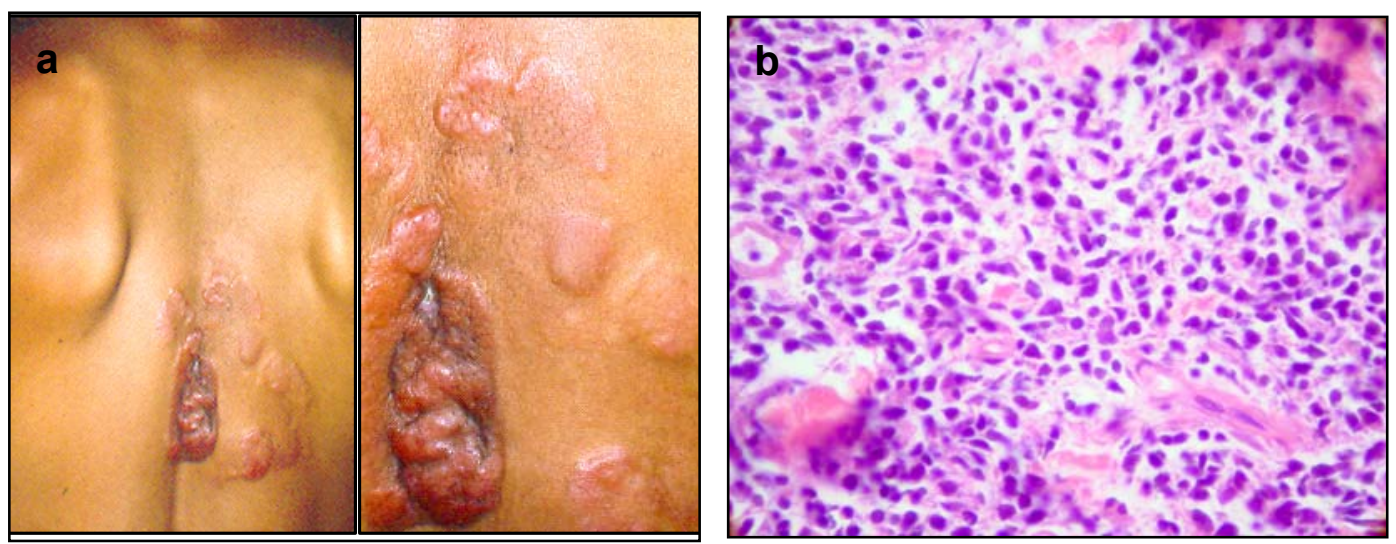

Figura 10a- Placas e tumores na região dorsal; 10b- Consistente com LCCB centro-folicular, padrão difuso, HE 400X
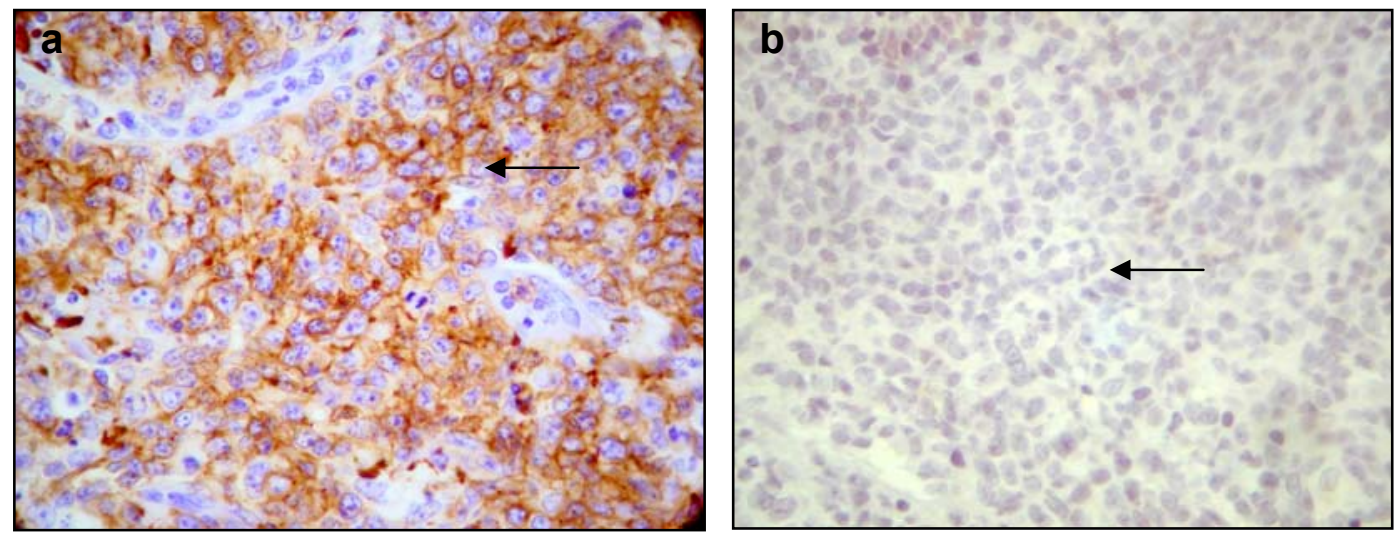

Figura 11a- Consistente com LCCB centro-folicular, CD 20 positivo nas células neoplásicas (seta), IIQ 400X; 11b- Consistente com LCCB centro-folicular, CD 10 negativo nas células neoplásicas (seta), IIQ 400X
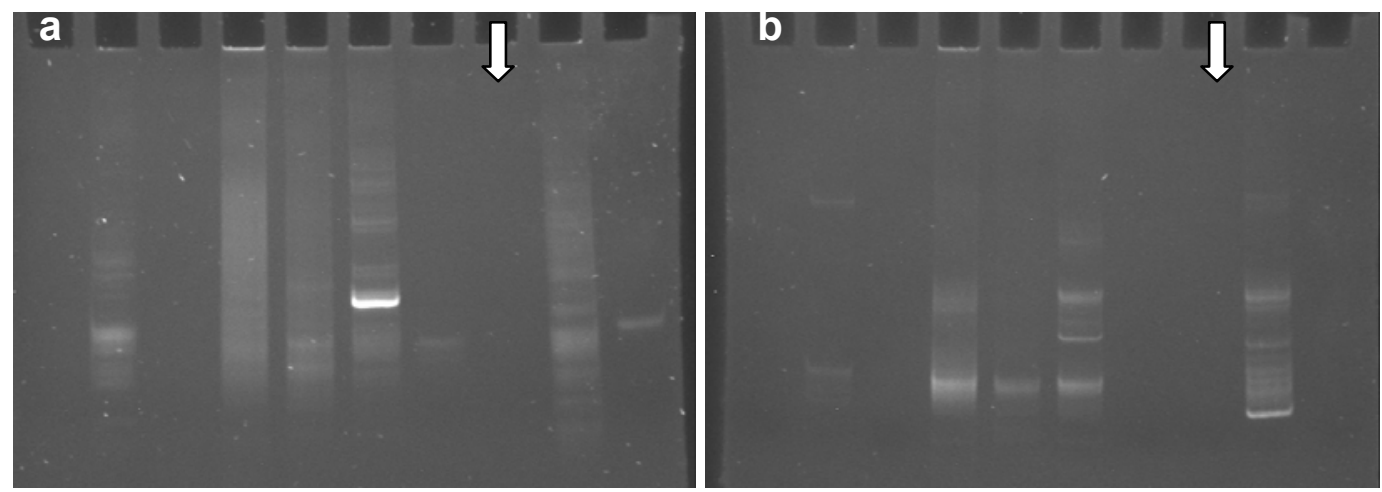

Figura 12 - Pesquisa da clonalidade não definida (seta) utilizando o protocolo lgH FR3 Nizet, e 12b - Pesquisa da clonalidade não definida (seta) utilizando o protocolo IgL Kappa 
Caso 1. Classificado como LCCB centro-folicular e resultado monoclonal
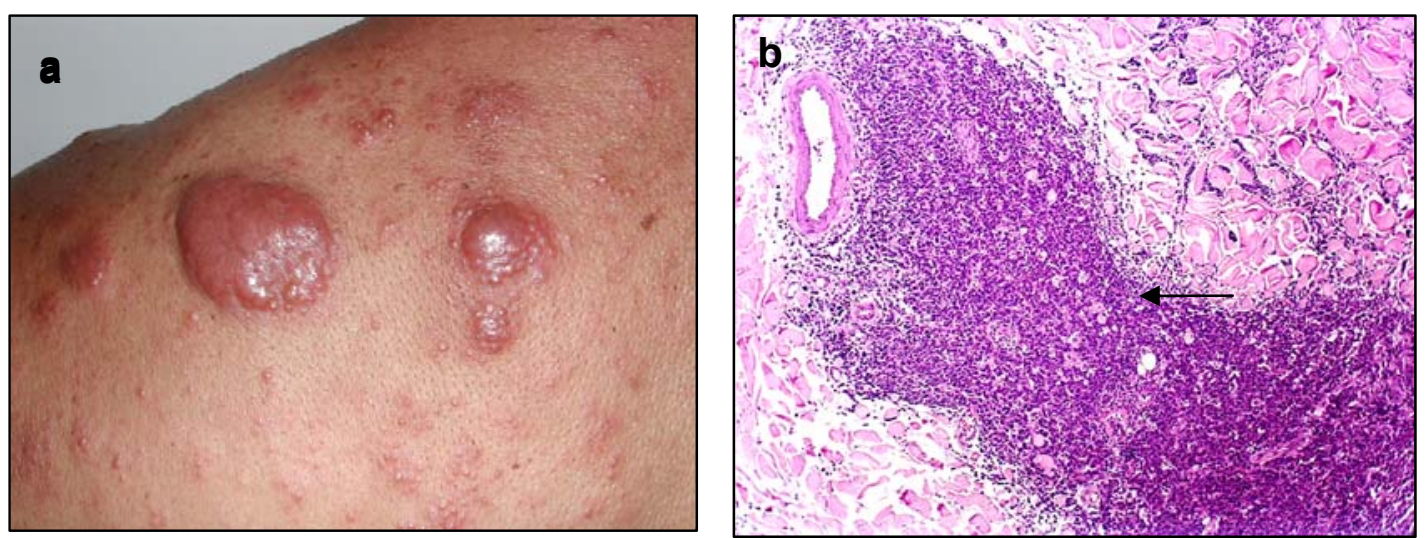

Figura 13a- Pápulas, nódulos e tumores na região dorsal; 13b- Consistente com LCCB centro-folicular, padrão de crescimento folicular (seta), HE 100X
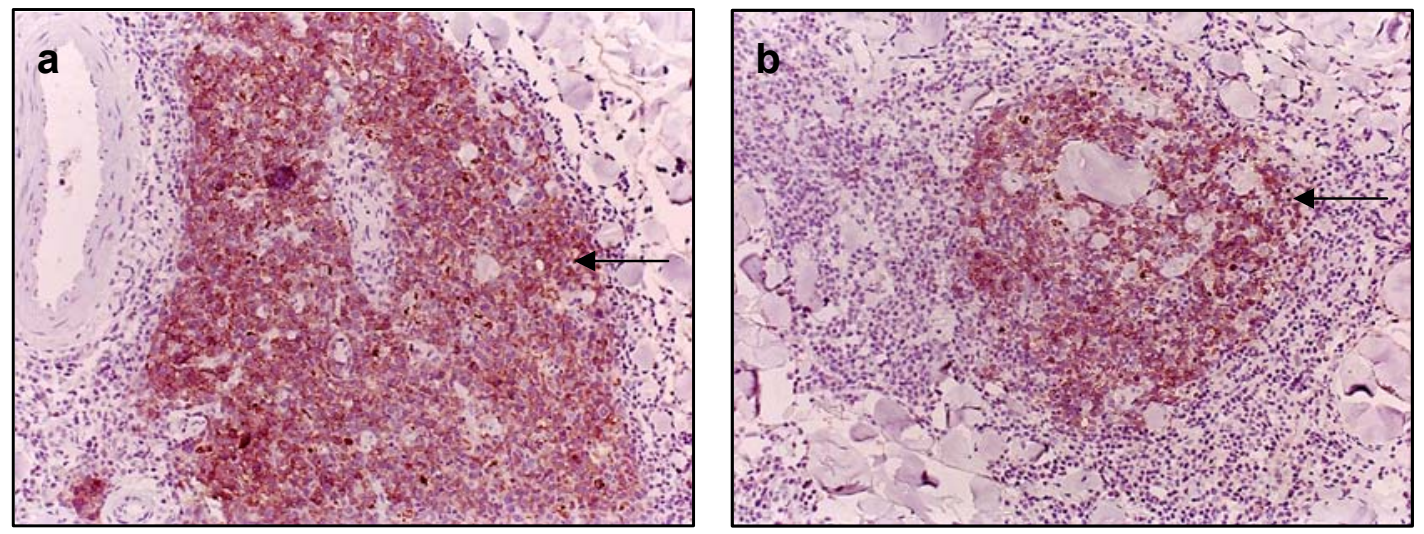

Figura 14a- Consistente com LCCB centro-folicular, CD 20 positivo nas células neoplásicas (seta), IIQ 200X; 14b- Consistente com LCCB centro-folicular, CD 10 positivo nas células neoplásicas (seta), IIQ 100X
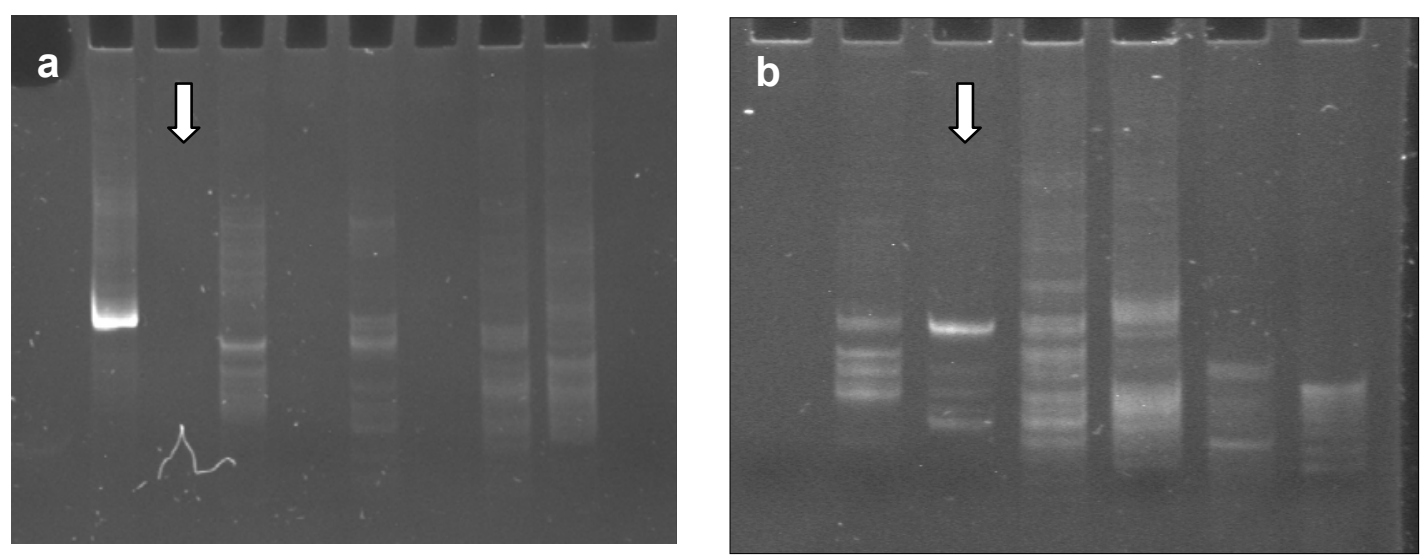

Figura 15a- Pesquisa da clonalidade não definida (seta) utilizando o protocolo $\lg \mathrm{H}$ FR3 Nizet, e 15b- monoclonalidade (seta) utilizando o protocolo IgL Kappa 
Caso 3. Classificado LCDGCB, tipo perna e clonalidade não definida
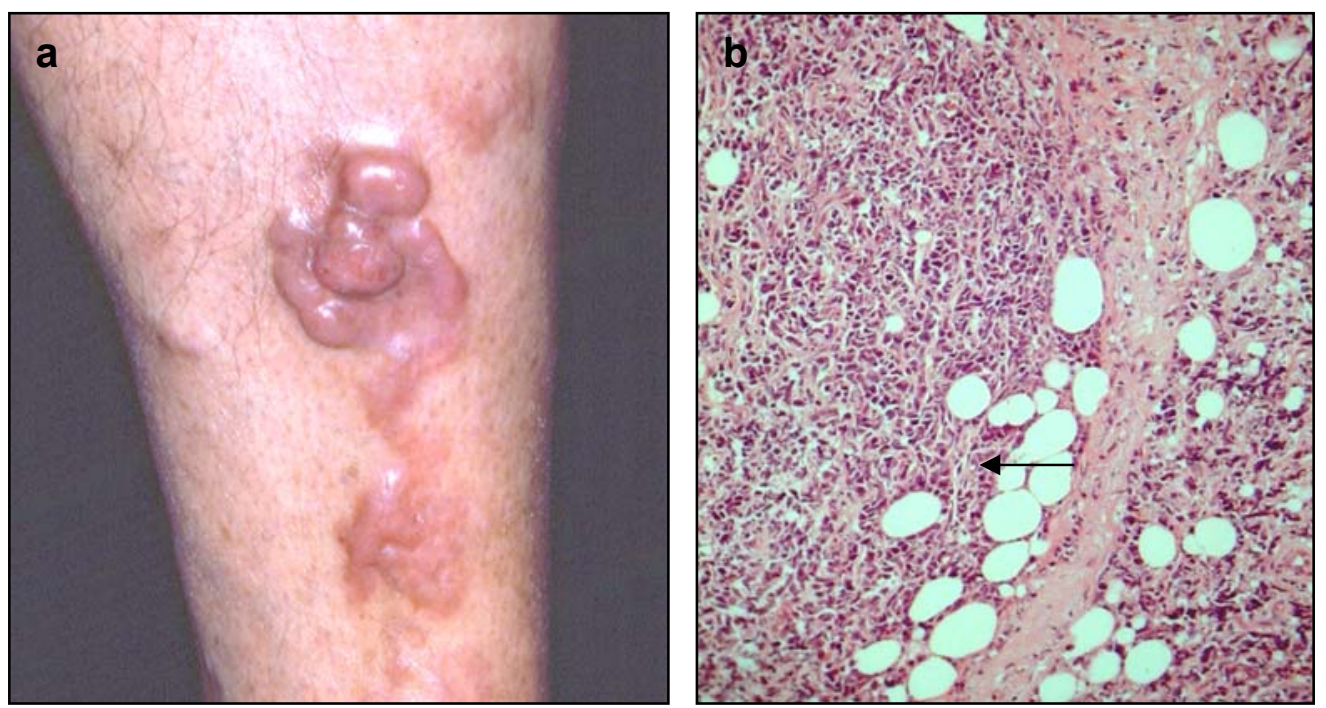

Figura 16a - Nódulos e placas na face anterior da perna; 16b- Consistente com LCDGCB, tipo perna, invasão tela subcutânea (seta), HE 100X
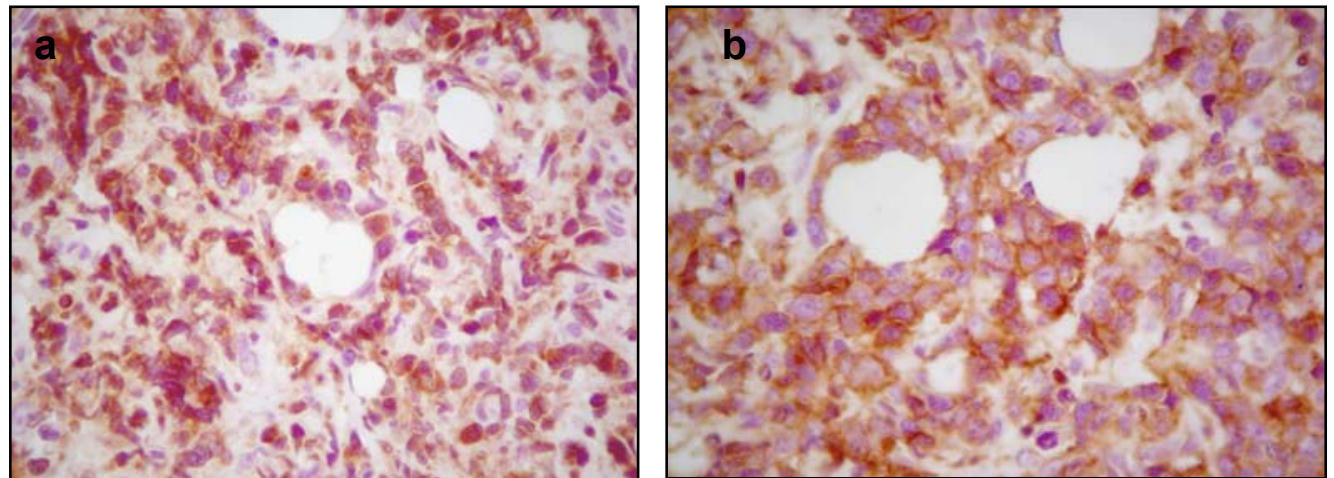

Figura 17a- Compatível com LCDGC, tipo perna: bcl-2 positivo nas células neoplásicas, IIQ 400X; 17 b: CD10 positivo nas células neoplásicas, IIQ $400 X$
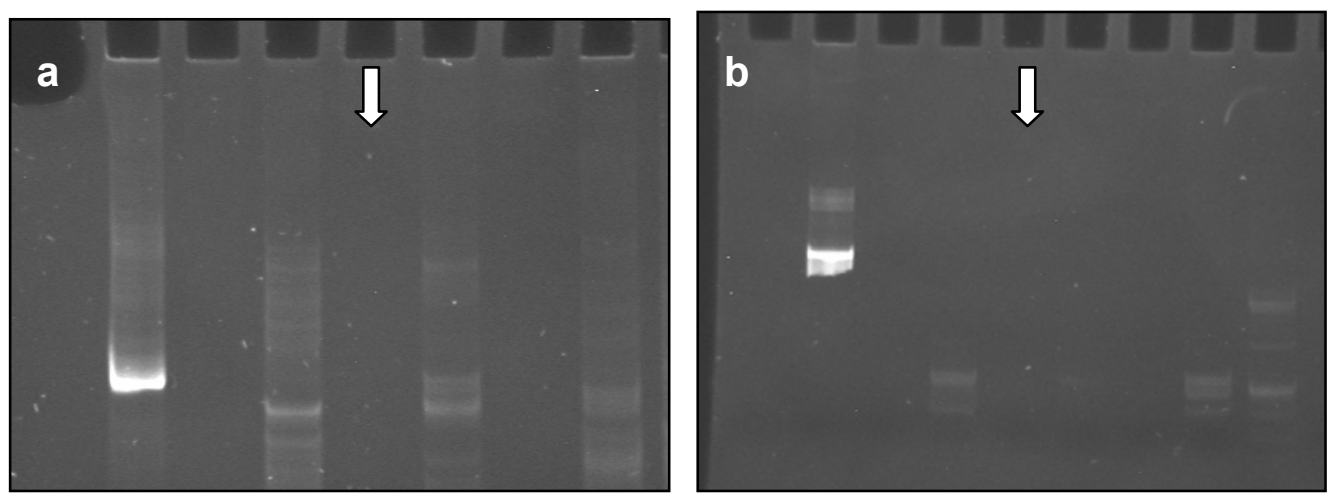

Figura 18a- Pesquisa da clonalidade não definida (seta) utilizando o protocolo IgH FR3 Nizet, e 18b- - Pesquisa da clonalidade não definida (seta) utilizando o protocolo IgL Kappa 
Caso 5. Classificado como Pseudolinfoma e clonalidade não definida
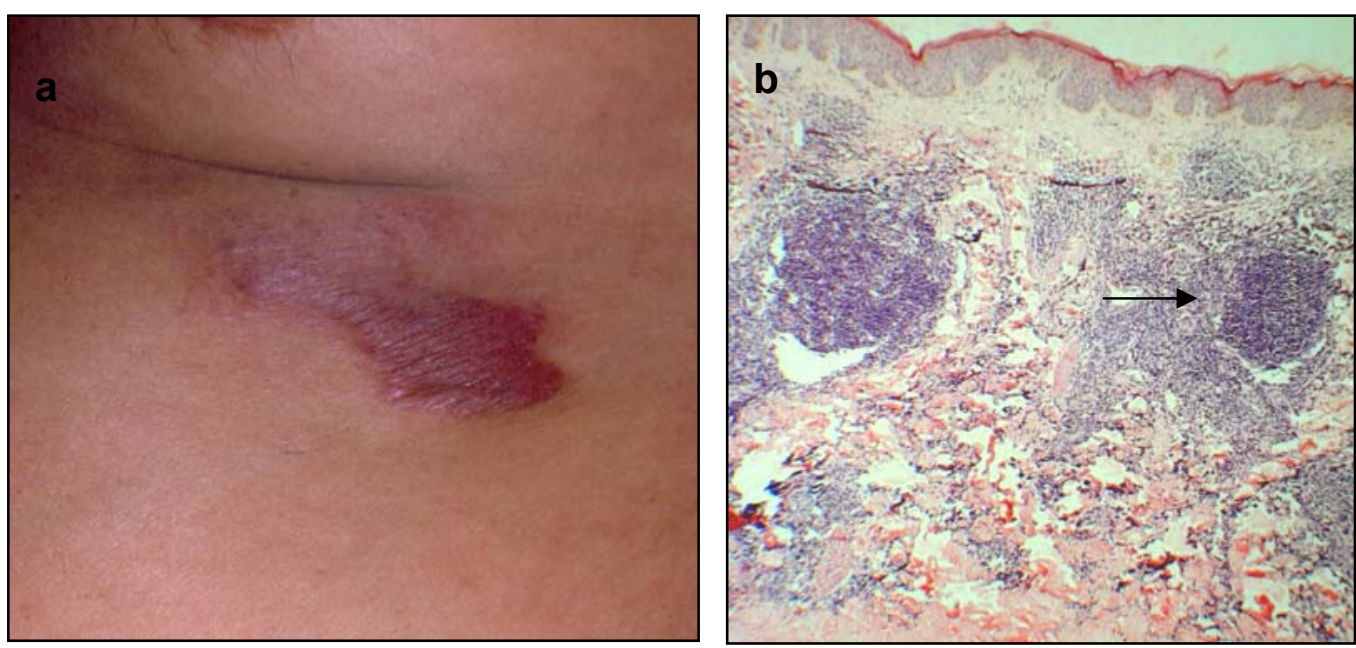

Figura 19a - Placa na região torácica antero-Iteral; 19b: Consistente com pseudolinfoma, padrão top-heavy (seta), HE 100X
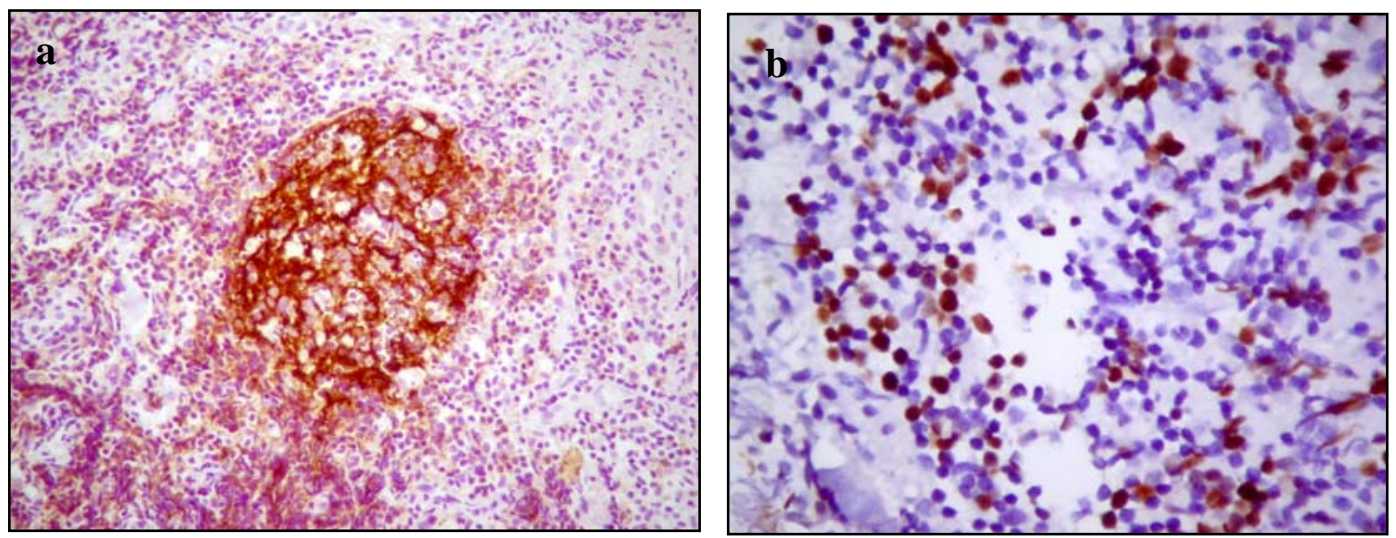

Figura 20 a: Consistente com pseudolinfoma, CD23 positivo esboçando folículo, IIQ 200X; e 20 b- Ki67 positivo indicando alto índice de proliferação, IIQ 400X
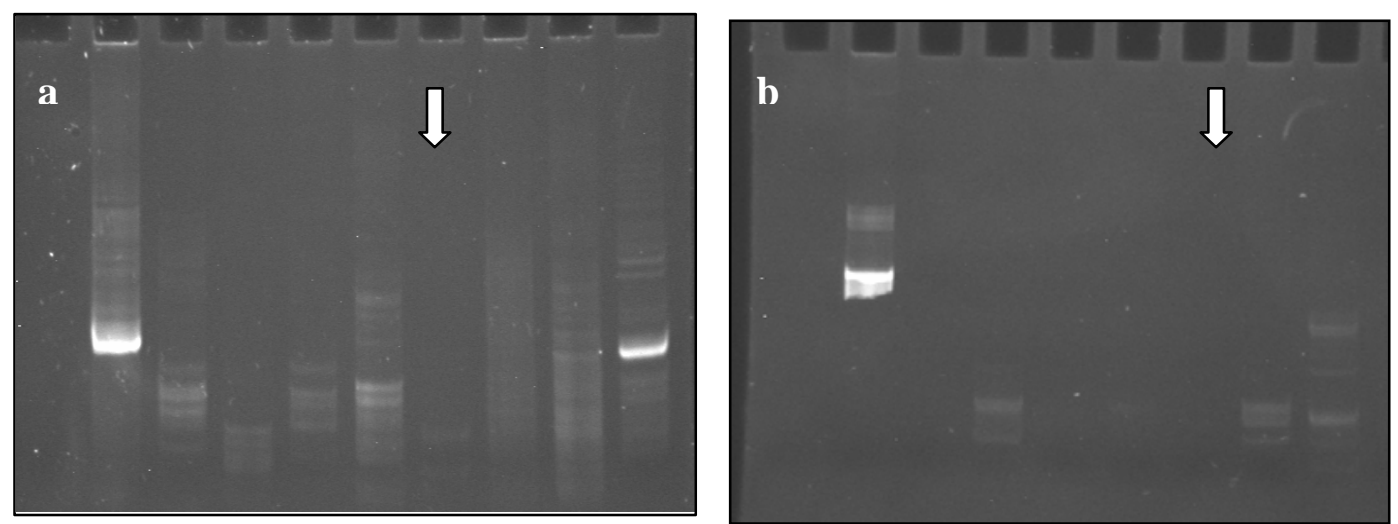

Figura 21a -Pesquisa da clonalidade não definida (seta) utilizando o protocolo IgH FR3 Nizet; 21b - pesquisa da clonalidade não definida (seta) utilizando protocolo IgL kappa 
Caso 6. Classificado com inconclusivo e resultado policlonal
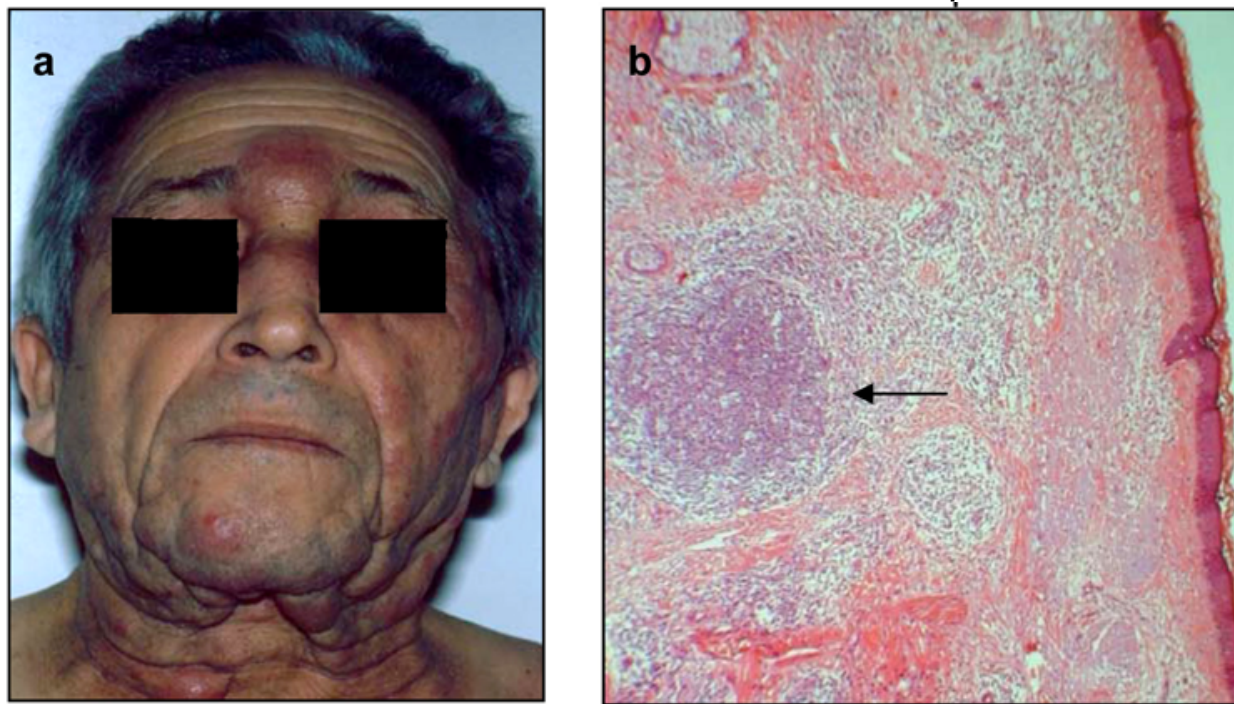

Figura 22a - Nódulos e placas na face e região cervical; ; 22b: Infiltrado celular ocupando toda derme, esboço folicular (seta), HE 100X
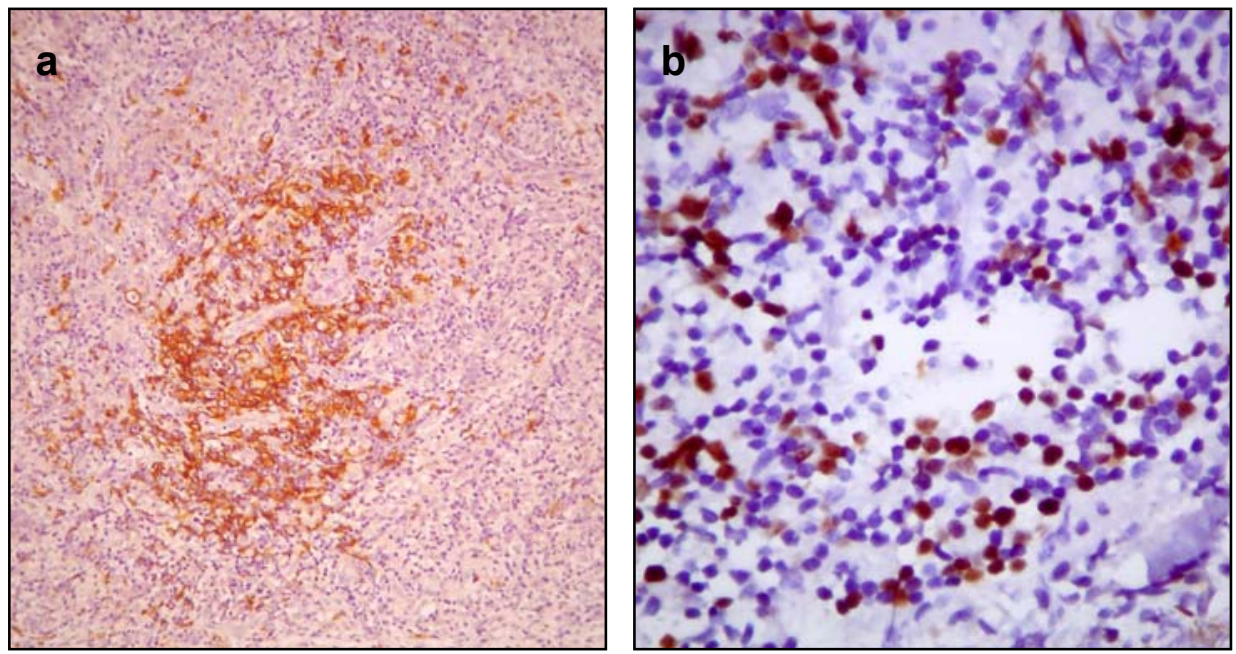

Figura 23a- CD20 positivo no centro do folículo, IIQ 400X; e 23b - Ki 67 positivo no centro do folículo , IIQ 400X
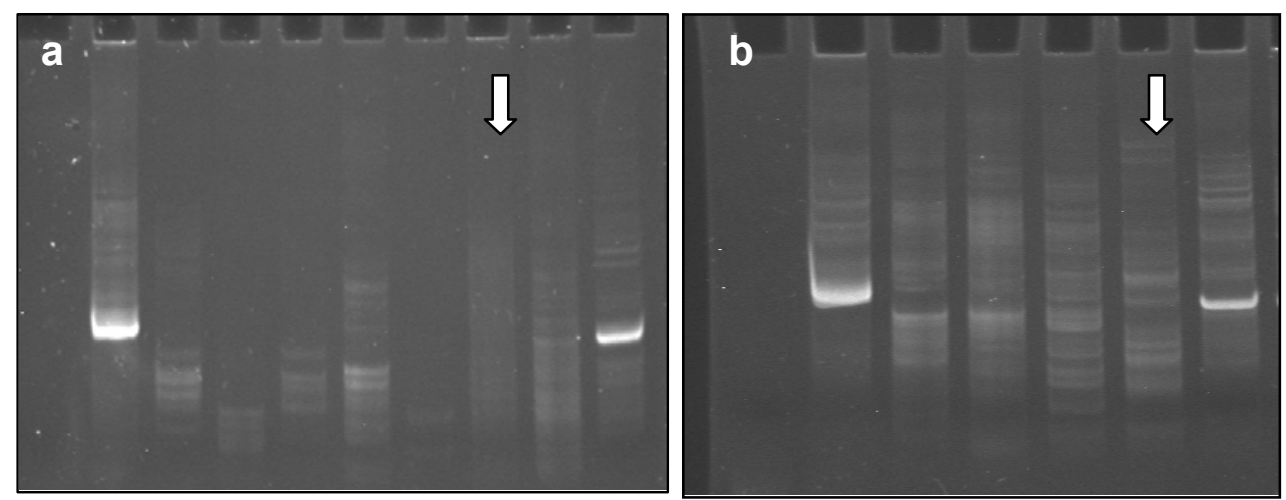

Figura 24a- Consistente com PLC, policlonalidade (seta) utilizando o protocolo IgH FR3 Nizet, 24b- policlonalidade (seta) utilizando o protocolo IgH FR3 Nizet duplicado para confirmar resultado 


\begin{abstract}
ANEXO B
PROTOCOLO PESQUISA DE CLONALIDADE NOS PROCESSOS LINFOPROLIFERATIVOS

Paciente : ,AP ID:
\end{abstract}

H\&E+ IIQ: $\square$ LCCB; $\square$ PLB; $\square$ inconclusivo

\title{
PESQUISA DA CLONALIDADE:
}

1. CONTROLE DE QUALIDADE DO DNA, $n$ : ; data $100 \mathrm{pb} ; \quad \square 100$ e $200 \mathrm{pb} ; \quad \square 100,200$ e $300 \mathrm{pb} ; \quad \square 100, \overline{200,300 \text { e } 400 \mathrm{pb}}$

2. Pesquisa do rearranjo IgH FR2/JH Biomed, $n$ : ; data

$\square$ Monoclonalidade; $\square$ policlonalidade; $\square$ inconclusivo

2. Pesquisa do rearranjo IgH FR2/JH Biomed, $n$ : ; data

$\square$ Monoclonalidade; $\square$ policlonalidade; $\square$ inconclusivo

3. Pesquisa do rearranjo IgH FR3/JH Biomed, $n$ : ; data

$\square$ Monoclonalidade; $\square$ policlonalidade; $\square$ inconclusivo

4. Pesquisa do rearranjo IgH FR3/JH clássico Nizet, $n$ : ; data

$\square$ Monoclonalidade; $\square$ policlonalidade; $\square$ inconclusivo

5.Pesquisa do rearranjo IgL Kappa $A, n$ : ; data

$\square$ Monoclonalidade; $\square$ policlonalidade; $\square$ inconclusivo

6.Pesquisa do rearranjo IgL Kappa $B, n$ : ; data

$\square$ Monoclonalidade; $\square$ policlonalidade; $\square$ inconclusivo

7. Pesquisa do rearranjo TCR (gamma A e B), $n$ :

$\square$ Monoclonalidade; $\square$ policlonalidade; $\square$ inconclusivo ; data

8. Pesquisa do rearranjo , n: ; data

Monoclonalidade; $\square$ policlonalidade; $\square$ inconclusivo; $\square$ duplicado

9. Pesquisa do rearranjo , $\mathrm{n}$ ; data

$\square$ Monoclonalidade; $\square$ policlonalidade; $\square$ inconclusivo; $\square$ duplicado

10. Pesquisa do rearranjo $\square$ Monoclonalidade; $\square$ policlonalidade; $\square$ inconclusivo; $\square$ duplicado ; data

11. Pesquisa do rearranjo , $\mathrm{n}$ ; data

$\square$ Monoclonalidade; $\square$ policlonalidade; $\square$ inconclusivo; $\square$ duplicado

12. Pesquisa do rearranjo , $\mathrm{n}$ ; data

$\square$ Monoclonalidade; $\square$ policlonalidade; $\square$ inconclusivo; $\square$ duplicado

LAUDO FINAL PESQUISA DA CLONALIDADE, $n$ : ; data 
ANEXO C

\begin{tabular}{|c|c|c|c|c|c|c|c|c|c|c|c|c|c|c|c|c|c|c|c|c|c|c|c|c|c|}
\hline ID & $\mathrm{HE}$ & 110 & HE+HQ & BM & HE/IIQ+BM & WHO-EORTC & $\mathrm{s}$ & Id & $R$ & HP & Dist & Localizaçăo & Morfologia & Diam & $\mathrm{N}$ & $L, M, V$ & Estagio & Status & Trat. & DNA & IgH F3 Nizet & $\operatorname{IgH}$ F3 & IgH F2 & IgL Kappa & NR \\
\hline 1 & LCCB & LCCB & LCCB & monoclonal & PCCB & centro-folicular & $\mathrm{m}$ & 54 & b & 6 & diss & face, pescoso, tronco e dorso & papula, nodulo & 1 & 10 & $\mathrm{~s}, \mathrm{~S}, \mathrm{~S}(30)$ & sistem & MCD (36) & QT & + & nd & nd & nd & monoclonal & 13 \\
\hline 2 & INC & INC & INC & monoclonal & LCCB & centro-folicular & if & 57 & b & 60 & reg & dorso & placa & 6 & 2 & $\mathrm{~N}, \mathrm{~N}, \mathrm{~N}$ & cut ativ & $\operatorname{VCD}(72)$ & MN,CT & ++ & monoclonal & nd & nd & policional & 13 \\
\hline 3 & LCCB & PLB & LCCB & Inconclusiva & LCCB & difuso gdes cel, perna & $\mathrm{m}$ & 76 & b & 6 & reg & mmii & nodulo, placa & 16 & 1 & $\mathrm{~N}, \mathrm{~N}, \mathrm{~N}$ & cut ativ & MCD (20) & $\mathrm{QT}, \mathrm{RT}$ & ++ & nd & nd & nd & nd & 7 \\
\hline 4 & LCCB & PLB & INC & policlonal & INC & $\mathrm{NA}$ & f & 63 & b & 240 & diss & mmss, dorso, palato & nodulo, placa & 10 & 10 & $N, N, N$ & cut ativ & $\operatorname{VCD}(176)$ & CET & ++ & policional & nd & nd & policlonal & 14 \\
\hline 5 & INC & PLB & PLB & inconclusiva & PLB & $\mathrm{NA}$ & $\mathrm{m}$ & 50 & b & 24 & reg & tronco anterior & placa & 5 & 1 & $N, N, N$ & cut ativ & $\operatorname{VCD}(129)$ & RT & +++ & nd & nd & nd & nd & 7 \\
\hline 6 & PLB & INC & INC & policlonal & INC & $\mathrm{NA}$ & $\mathrm{m}$ & 71 & $\mathrm{~b}$ & 24 & diss & face, pescoço, tronco e dorso & nodulo, placa & 3 & 20 & $N, N, N$ & cut ativ & MCD (32) & CET & ++ & policional & nd & nd & policlonal & 13 \\
\hline 7 & PLB & LCCB & LCCB & monoclonal & LCCB & centro-folicular & m & 67 & b & 6 & reg & dorso & placa & 3 & 1 & $\mathrm{~N}, \mathrm{~N}, \mathrm{~N}$ & cut ativ & $\operatorname{VCD}(36)$ & СET & ++ & monoclonal & nd & nd & monoclonal & 13 \\
\hline 8 & PLB & PLB & PLB & Inconclusiva & PLB & $\mathrm{NA}$ & if & 36 & b & 48 & diss & mmss e mmii & papula, nodulo & 2 & 15 & $\mathrm{~N}, \mathrm{~N}, \mathrm{~N}$ & cut ativ & $\operatorname{VCD}(13)$ & CET & + & nd & nd & nd & nd & 7 \\
\hline 10 & LCCB & LCCB & LCCB & monoclonal & LCCB & zona marginal & $f_{f}$ & 37 & $\mathrm{~b}$ & 120 & diss & tronco ant, dorso e mmii & papula, nodulo, placa & 2 & 20 & N,N,N & cut ativ & $\operatorname{vCD}(143)$ & QT, RT & ++ & monoclonal & nd & nd & monoclonal & 11 \\
\hline 11 & LCCB & PLB & INC & Inconclusiva & INC & $\mathrm{NA}$ & if & 62 & b & 6 & reg & dorso & nodulo & 1 & 2 & $\mathrm{~N}, \mathrm{~N}, \mathrm{~N}$ & cut rem & VSD (169) & EX & + & nd & nd & nd & nd & 7 \\
\hline 12 & PLB & LCCB & LCCB & monoclonal & LCCB & centro-folicular & $f_{f}$ & 43 & n & 0,5 & reg & face & papula, nodulo & 0,5 & 5 & N,N,N & cut rem & VSD (108) & EX & +++ & policlonal & policlonal & nd & monoclonal & 13 \\
\hline 13 & INC & INC & INC & policlonal & INC & $\mathrm{NA}$ & f & 26 & b & 12 & reg & dorso & nodulo & 8 & 1 & $\mathrm{~N}, \mathrm{~N}, \mathrm{~N}$ & cut rem & VSD (6) & EX & + & policlonal & nd & nd & policlonal & 11 \\
\hline 14 & LCCB & LCCB & LCCB & monoclonal & LCCB & centro-folicular & $\mathrm{m}$ & 74 & b & 24 & reg & tronco anterior & papula, placa & 5 & 7 & $N, N, N$ & cut ativ & $\operatorname{VCD}(14)$ & QT,RT & ++ & monoclonal & nd & nd & monoclonal & 11 \\
\hline 15 & LCCB & LCCB & LCCB & inconclusiva & LCCB & centro-folicular & $\mathrm{m}$ & 29 & b & 24 & reg & dorso & papula, nodulo & 2 & 8 & $\mathrm{~N}, \mathrm{~N}, \mathrm{~N}$ & cut rem & VSD (149) & RT & + & nd & nd & nd & nd & $9_{9}$ \\
\hline 16 & LCCB & $\angle C C B$ & LCCB & inconclusiva & LCCB & centro-folicular & $\mathrm{m}$ & 40 & b & 24 & reg & dorso & placa & 15 & 1 & $\mathrm{~N}, \mathrm{~N}, \mathrm{~N}$ & cut rem & VSD (71) & $\mathrm{QTT}, \mathrm{RT}$ & ++ & nd & nd & nd & nd & 8 \\
\hline 17 & INC & PLB & PLB & policlonal & PLB & $\mathrm{NA}$ & $f_{f}$ & 40 & b & 48 & reg & mmss & papula & 1 & 3 & $\mathrm{~N}, \mathrm{~N}, \mathrm{~N}$ & cut rem & VSD (17) & EX & +++ & policlonal & nd & nd & policlonal & 8 \\
\hline 18 & INC & INC & INC & policlonal & INC & $\mathrm{NA}$ & if & 62 & b & 12 & reg & gluteo & nodulo & 3 & 1 & N,N,N & cut ativ & $\operatorname{VCD}(72)$ & EX & ++ & policlonal & nd & nd & nd & 11 \\
\hline 19 & PLB & PLB & PLB & policlonal & PLB & $\mathrm{NA}$ & $f_{f}$ & 32 & $\mathrm{~m}$ & 60 & reg & mmss & nodulo & 1 & 1 & N,N,N & cut rem & VSD (72) & EX & + & policlonal & nd & nd & nd & 7 \\
\hline 20 & LCCB & LCCB & LCCB & monoclonal & LCCB & centro-folicular & $\mathrm{m}$ & 65 & b & 48 & reg & couro cabeludo & placa & 5 & 1 & N,N,N & cut ativ & $\operatorname{VCD}(6)$ & EX & ++ & policlonal & nd & nd & monoclonal & 13 \\
\hline 21 & PLB & PLB & PLB & policlonal & PLB & $\mathrm{NA}$ & $\mathrm{m}$ & 85 & $\mathrm{~m}$ & 24 & reg & face & papula, nodulo & 5 & 3 & $\mathrm{~N}, \mathrm{~N}, \mathrm{~N}$ & cut ativ & $\operatorname{VCD}(36)$ & Ст & ++ & policlonal & policional & nd & policlonal & 8 \\
\hline 22 & PLB & INC & INC & policlonal & INC & $\mathrm{NA}$ & $\mathrm{m}$ & 51 & $\mathrm{~b}$ & 48 & reg & face & papula, nodulo & 3 & 3 & N,N,N & cut ativ & $\operatorname{vCD}(72)$ & CT & +++ & policlonal & nd & nd & policlonal & 14 \\
\hline 23 & LCCB & LCCB & LCCB & policlonal & LCCB & centro-folicular & f & 68 & b & 3 & reg & couro cabeludo & nodulo & 3 & 2 & $\mathrm{~N}, \mathrm{~N}, \mathrm{~N}$ & cut ativ & $\operatorname{VCD}(27)$ & EX & ++ & policional & nd & nd & policional & 7 \\
\hline 24 & LCCB & PLB & INC & monoclonal & PCCB & centro-folicular & $\mathrm{m}$ & 64 & b & 6 & reg & dorso & nodulo & 5 & 1 & N,N,N & cut rem & VSD (30) & EX & +++ & monoclonal & monoclonal & nd & monoclonal & 12 \\
\hline 25 & LCCB & PLB & INC & policlonal & INC & $\mathrm{NA}$ & $\mathrm{m}$ & 23 & $\mathrm{~b}$ & 8 & reg & mmss & placa & 1 & 1 & $N, N, N$ & cut ativ & $\operatorname{VCD}(66)$ & Ex & + & policional & nd & nd & policlonal & 14 \\
\hline 26 & LCCB & INC & LCCB & policlonal & LCCB & zona marginal & $\mathrm{m}$ & 45 & b & 96 & diss & tronco, mmss, mmii & papula, nodulo & 2 & 9 & $\mathrm{~N}, \mathrm{NNN}$ & cut ativ & $\operatorname{vCD}(6)$ & EX & ++ & policlonal & nd & nd & policlonal & 9 \\
\hline 27 & INC & INC & INC & inconclusiva & INC & $\mathrm{NA}$ & $\mathrm{m}$ & 36 & b & 48 & diss & tronco, mmss, mmii & macula, papula, placa & 3 & 6 & $\mathrm{~N}, \mathrm{~N}, \mathrm{~N}$ & cut ativ & $\operatorname{VCD}(64)$ & ст & ++ & nd & nd & nd & nd & 8 \\
\hline 29 & LCCB & LCCB & LCCB & monoclonal & LCCB & centro-folicular & $\mathrm{m}$ & 45 & b & 1 & reg & couro cabeludo & nodulo & 1 & 1 & N,N,N & cut ativ & $\operatorname{VCD}(13)$ & Ex & + & policlonal & nd & nd & monoclonal & 11 \\
\hline 30 & LCCB & LCCB & LCCB & monoclonal & LCCB & centro-folicular & $\mathrm{m}$ & 30 & b & 6 & reg & couro cabeludo & nodulo & 2 & $l_{1}$ & N,N,N & cut rem & VSD (20) & RT & ++ & policlonal & nd & nd & monoclonal & 8 \\
\hline 31 & PLB & PLB & PLB & policlonal & PLB & NA & $\mathrm{m}$ & 31 & $\mathrm{~b}$ & 8 & reg & couro cabeludo & nodulo & 2 & 1 & $N, N, N$ & cut rem & |VSD (24) & $\mathrm{CT}, \mathrm{AB}$ & +++ & policlonal & nd & nd & policional & 11 \\
\hline
\end{tabular}

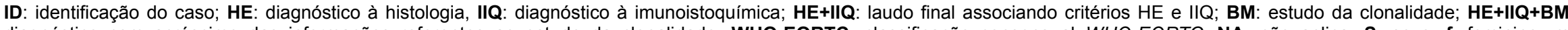
diagnóstico com acréscimo das informações referentes ao estudo da clonalidade; WHO-EORTC: classificação consensual WHO-EORTC; NA: não aplica; S: sexo; f: feminino; m: masculino; Id: idade de acometimento da doença; R: raça; b: branco; $\mathbf{n}$ :negro; m: mulato; HP: tempo de história pregressa; Distr: distribuição corporal; mmii: membros inferiores; mmss membros superiores; Diam: maior diâmetro da lesão; $\mathbf{N}$ : numero das lesões; L: comprometimento linfonodal; $\mathbf{M}$ : comprometimento medula óssea; $\mathbf{V}$ : comprometimento visceral; $\mathbf{S}$ : sim, $\mathbf{N}$ : membros superiores, Diam: maior diâmetro da lesão; N. numero das lesôes, L. comprometimento linfonodal; M: comprometimento medula ossea; V: comprometimento visceral, S.Sim, N: tratamento; QT: quimioterapia; MN: mostarda nitrogenada; CT: corticoide tópico; RT: radioterapia; EX: exérese cirúrgica; DNA: qualidade do DNA na amostra; +: 100 pb; ++ 100 e 200pb; +++: 100, 200 e 300pb; nd: não definido, NR: número de reações para pesquisa de clonalidade. 


\section{ANEXO D}

Tabela 15 - Classificação à histologia (HE), laudo final da revisão anatomopatológica (HE e imunoistoquímica) e resultado da pesquisa de clonalidade através da biologia molecular nos 29 de processos linfoproliferativos de células $B$

\begin{tabular}{|c|c|c|c|}
\hline ID $^{*}$ & Laudo HE** & Laudo final $(\mathrm{HE}+\| \mathrm{QQ})^{* * *}$ & $\mathrm{BM}^{* * * *}$ \\
\hline 1 & LCCB & LCCB & monoclonal \\
\hline 2 & INC & INC & monoclonal \\
\hline 3 & LCCB & $\mathrm{LCCB}^{\#}$ & inconclusiva \\
\hline 4 & LCCB & INC & policlonal \\
\hline 5 & INC & PLB & inconclusiva \\
\hline 6 & PLB & INC & policlonal \\
\hline 7 & PLB & LCCB & monoclonal \\
\hline 8 & PLB & PLB & inconclusiva \\
\hline 10 & LCCB & LCCB & monoclonal \\
\hline 11 & LCCB & INC & inconclusiva \\
\hline 12 & PLB & LCCB & monoclonal \\
\hline 13 & INC & INC & policlonal \\
\hline 14 & LCCB & $\mathrm{LCCB}^{\#}$ & monoclonal \\
\hline 15 & LCCB & $\mathrm{LCCB}^{\#}$ & inconclusiva \\
\hline 16 & $\mathrm{LCCB}$ & $\mathrm{LCCB}^{\#}$ & inconclusiva \\
\hline 17 & INC & PLB & policlonal \\
\hline 18 & INC & INC & policlonal \\
\hline 19 & PLB & PLB & policlonal \\
\hline 20 & LCCB & $\mathrm{LCCB}^{\#}$ & monoclonal \\
\hline 21 & PLB & PLB & policlonal \\
\hline 22 & PLB & INC & policlonal \\
\hline 23 & LCCB & $\mathrm{LCCB}^{\#}$ & policlonal \\
\hline 24 & LCCB & INC & monoclonal \\
\hline 25 & LCCB & INC & policlonal \\
\hline 26 & LCCB & LCCB & policlonal \\
\hline 27 & INC & INC & inconclusiva \\
\hline 29 & LCCB & LCCB & monoclonal \\
\hline 30 & LCCB & LCCB & monoclonal \\
\hline 31 & PLB & PLB & policlonal \\
\hline
\end{tabular}

*ID: identificação do caso;

** HE: Diagnóstico a Hematoxilina - eosina;

***HE+IIQ: Diagnostico da associação dos métodos HE e Imunoistoquímica;

****BM: definição da clonalidade pela biologia molecular;

LCCB: linfoma cutâneo primário de células B;

PLB: pseudolinfoma cutâneo de células B;

INC: inconclusivo;

\# casos com predomínio de grandes células B no infiltrado em estudo. 
Tabela 16 - Resultados quanto à distribuição, localização, morfologia, número e diâmetro das lesões nos 29 casos de processos linfoproliferativos de células B

\begin{tabular}{|c|c|c|c|c|}
\hline & Linfomas & Pseudolinfomas & Inconclusivos & Total \\
\hline Distribuição & $10(77 \%)$ & $5(83 \%)$ & $7(70 \%)$ & 22 \\
\hline Não regional & $3(23 \%)$ & $1(17 \%)$ & $3(30 \%)$ & 7 \\
\hline Segm. cefálico & $5(38 \%)$ & $2(33 \%)$ & $1(10 \%)$ & 8 \\
\hline Tronco anterior & $1(8 \%)$ & $1(17 \%)$ & 0 & 2 \\
\hline Dorso & $3(23 \%)$ & 0 & $4(40 \%)$ & 7 \\
\hline Membros & $1(8 \%)$ & $3(50 \%)$ & $2(20 \%)$ & 6 \\
\hline Segm. cefálico e tronco & $1(8 \%)$ & 0 & $1(10 \%)$ & 2 \\
\hline Tronco e membros & $2(15 \%)$ & 0 & $1(10 \%)$ & 3 \\
\hline Segm. cefálico, tronco e membros & 0 & 0 & $1(10 \%)$ & 1 \\
\hline Morfologia & 0 & 0 & 0 & 0 \\
\hline Pápula & 0 & $1(17 \%)$ & 0 & 1 \\
\hline Placa & $3(23 \%)$ & $1(17 \%)$ & $2(20 \%)$ & 6 \\
\hline Nódulo & $3(23 \%)$ & $2(33 \%)$ & $4(40 \%)$ & 9 \\
\hline Coexistência de lesões & $7(54 \%)$ & $2(33 \%)$ & $4(40 \%)$ & 13 \\
\hline Número & $6(46 \%)$ & $3(50 \%)$ & $4(40 \%)$ & 13 \\
\hline $2-10$ & $6(46 \%)$ & $2(33 \%)$ & $5(50 \%)$ & 13 \\
\hline$>10$ & $1(8 \%)$ & $1(17 \%)$ & $1(10 \%)$ & 3 \\
\hline Diâmetro & $1(8 \%)$ & 0 & 0 & 1 \\
\hline $1-5 \mathrm{~cm}$ & $10(77 \%)$ & $6(100 \%)$ & $7(70 \%)$ & 23 \\
\hline$>5 \mathrm{~cm}$ & $2(15 \%)$ & 0 & $3(30 \%)$ & 5 \\
\hline
\end{tabular}

Tabela 17 - Status do paciente na última avaliação ou óbito nos 29 casos de processos linfoproliferativos de células B

\begin{tabular}{ccccc}
\hline & Linfoma cutâneo & Pseudolinfoma & Inconclusivo & Total \\
\hline Vivo Sem Doença & $4(31 \%)$ & $3(50 \%)$ & $3(30 \%)$ & $\mathbf{1 0}$ \\
Vivo Com Doença & $7(54 \%)$ & $3(50 \%)$ & $6(60 \%)$ & $\mathbf{1 6}$ \\
Morto Com Doença $^{\dagger}$ & $2(15 \%)^{\dagger}$ & - & $1(10 \%)^{*}$ & $\mathbf{3}$ \\
Morto Sem Doença $_{\text {Total }}$ & - & - & - & $\mathbf{0}$ \\
\hline & $\mathbf{1 3}$ & $\mathbf{6}$ & $\mathbf{1 0}$ & $\mathbf{2 9}$ \\
\hline
\end{tabular}

\footnotetext{
† 2 casos (caso 1 e 3) classificados como linfomas cutâneos, causa mortis relacionado indiretamente ao linfoma.

"caso 6 inconclusivo ao $\mathrm{HE} / \mathrm{IIQ}$, reclassificados como pseudolinfoma, causa mortis relacionada diretamente a doença.
} 
REFERÊNCIAS 
(1) Alizadeh AA, Eisen MB, Davis RE, Ma C, Lossos IS, Rosenwald A, et al. Distinct types of diffuse large B-cell lymphoma identified by gene expression profiling. Nature 2000 Feb 3;403(6769):503-11.

(2) Cerroni L. Lymphoproliferative lesions of the skin. J Clin Pathol 2006 Aug;59(8):813-26.

(3) Kerl H, Cerroni L. Primary cutaneous B-cell lymphomas: then and now. J Cutan Pathol 2006 Feb;33 Suppl 1:1-5.

(4) Burg G, Kerl H, Przybilla B, Braun-Falco O. Some statistical data, diagnosis, and staging of cutaneous B-cell lymphomas. J Dermatol Surg Oncol 1984 Apr;10(4):256-62.

(5) Evans HL, Winkelmann RK, Banks PM. Differential diagnosis of malignant and benign cutaneous lymphoid infiltrates: a study of 57 cases in which malignant lymphoma had been diagnosed or suspected in the skin. Cancer 1979 Aug;44(2):699-717.

(6) Rappaport H. Tumors of the hematopoietic system - Atlas of Tumor Pathology. Armed Forces Institute of Pathology ed. Washington: 1966.

(7) Weinstock MA, Horm JW. Mycosis fungoides in the United States. Increasing incidence and descriptive epidemiology. JAMA 1988 Jul 1;260(1):42-6.

(8) Levy R, Warnke R, Dorfman RF, Haimovich J. The monoclonality of human B-cell lymphomas. J Exp Med 1977 Apr 1;145(4):1014-28.

(9) Slater DN. MALT and SALT: the clue to cutaneous B-cell lymphoproliferative disease. Br J Dermatol 1994 Oct;131(4):557-61.

(10) Willemze R, Beljaards RC, Meijer CJ, Rijlaarsdam JR. Classification of primary cutaneous lymphomas. Historical overview and perspectives. Dermatology 1994;189 Suppl 2:8-15.

(11) Bogle MA, Riddle CC, Triana EM, Jones D, Duvic M. Primary cutaneous B-cell lymphoma. J Am Acad Dermatol 2005 Sep;53(3):479-84.

(12) Fung MA, Murphy MJ, Hoss DM, Grant-Kels JM. Practical evaluation and management of cutaneous lymphoma. J Am Acad Dermatol 2002 Mar;46(3):325-57.

(13) Willemze R, Meijer CJ. EORTC classification for primary cutaneous lymphomas: a comparison with the R.E.A.L. Classification and the proposed WHO Classification. Ann Oncol 2000;11 Suppl 1:11-5. 
(14) Campo E, Chott A, Kinney MC, Leoncini L, Meijer CJ, Papadimitriou CS, et al. Update on extranodal lymphomas. Conclusions of the Workshop held by the EAHP and the SH in Thessaloniki, Greece. Histopathology 2006 Apr;48(5):481-504.

(15) Harris NL, Jaffe ES, Stein H, Banks PM, Chan JK, Cleary ML, et al. A revised European-American classification of lymphoid neoplasms: a proposal from the International Lymphoma Study Group. Blood 1994 Sep 1;84(5):1361-92.

(16) Harris NL, Jaffe ES, Diebold J, Flandrin G, Muller-Hermelink HK, Vardiman J. Lymphoma classification--from controversy to consensus: the R.E.A.L. and WHO Classification of lymphoid neoplasms. Ann Oncol 2000;11 Suppl 1:3-10.

(17) Willemze R, Kerl H, Sterry W, Berti E, Cerroni L, Chimenti S, et al. EORTC classification for primary cutaneous lymphomas: a proposal from the Cutaneous Lymphoma Study Group of the European Organization for Research and Treatment of Cancer. Blood 1997 Jul 1;90(1):354-71.

(18) Willemze R, Meijer CJ. Classification of primary cutaneous B-cell lymphomas: EORTC classification or REAL classification? $\mathrm{Br} \mathrm{J}$ Dermatol 1999 Aug;141(2):350-2.

(19) Willemze R, Jaffe ES, Burg G, Cerroni L, Berti E, Swerdlow SH, et al. WHO-EORTC classification for cutaneous lymphomas. Blood 2005 May 15;105(10):3768-85.

(20) Bacchi MM., Alves VAF BCVJ. Linfomas não-Hodgkin de células B. Manual de imuno-histoquímica. São Paulo: Sociedade Brasileira de Dermatologia; 1999. p. 135-40.

(21) Rijlaarsdam U, Bakels V, van Oostveen JW, Gordijn RJ, Geerts ML, Meijer CJ, et al. Demonstration of clonal immunoglobulin gene rearrangements in cutaneous B-cell lymphomas and pseudo-B-cell lymphomas: differential diagnostic and pathogenetic aspects. J Invest Dermatol 1992 Dec;99(6):749-54.

(22) Abbas AK LAPJS. Lymphocyte maturation and expression of antigen receptor genes. In: W.B.Saunders, editor. Cellular and molecular immunology. $4^{\text {th }}$ ed. ed. Philadelphia: 2000. p. 125-60.

(23) Santucci M, Pimpinelli N. Primary cutaneous B-cell lymphomas. Current concepts. I. Haematologica 2004 Nov;89(11):1360-71.

(24) Martensson IL, Keenan RA, Licence S. The pre-B-cell receptor. Curr Opin Immunol 2007 Apr;19(2):137-42. 
(25) Jaffe ES, Sander CA, Flaig MJ. Cutaneous lymphomas: a proposal for a unified approach to classification using the R.E.A.L./WHO Classification 2. Ann Oncol 2000;11 Suppl 1:17-21.

(26) Burg G, Kerl H, Schmoeckel C. Differentiation between malignant B-cell lymphomas and pseudolymphomas of the skin. J Dermatol Surg Oncol 1984 Apr;10(4):271-5.

(27) Ploysangam T, Breneman DL, Mutasim DF. Cutaneous pseudolymphomas. J Am Acad Dermatol 1998 Jun;38(6 Pt 1):877-95.

(28) Jaffe ES, Harris NL, Stein H, Vardiman JW. Classification of tumours, pathology \& genetics, tumours of hematopoietic and lymphoid tissues.Lyon: IARC; 2001.

(29) Zackheim HS, Vonderheid EC, Ramsay DL, LeBoit PE, Rothfleisch J, Kashani-Sabet M. Relative frequency of various forms of primary cutaneous lymphomas. J Am Acad Dermatol 2000 Nov;43(5 Pt 1):793-6.

(30) Stansfeld AG, Diebold J, Noel H, Kapanci Y, Rilke F, Kelenyi G, et al. Updated Kiel classification for lymphomas. Lancet 1988 Feb 6;1(8580):292-3.

(31) Lukes RJ, Collins RD. Immunologic characterization of human malignant lymphomas. Cancer 1974 Oct;34(4 Suppl):suppl-503.

(32) Melotti CZ SJ. Processos linfoproliferativos cutâneos de células B: a difícil distinção entre linfomas e pseudolinfomas. [dissertação]. São Paulo. Faculdade de Medicina da Universidade de São Paulo; 2004.

(33) Sampaio SAP., Rivitti EA. Dermatologia. Glossário dermatológico.São Paulo: Artes Médicas; 1998. p. 71-8.

(34) Moricz CZM, Sanches Jr.JA. Processos linfoproliferativos da pele. Parte 1 - Linfomas cutâneos de células B. An Bras Dermatol. 80 (5), 461-471. 9-9-2005.

(35) Pandolfino TL, Siegel RS, Kuzel TM, Rosen ST, Guitart J. Primary cutaneous B-cell lymphoma: review and current concepts. J Clin Oncol 2000 May;18(10):2152-68.

(36) Sander CA, Flaig MJ. Morphologic spectrum of cutaneous B-cell lymphomas. Dermatol Clin 1999 Jul;17(3):593-9, ix.

(37) Kerl H, Fink-Puches R, Cerroni L. Diagnostic criteria of primary cutaneous B-cell lymphomas and pseudolymphomas. Keio J Med 2001 Dec;50(4):269-73. 
(38) Slater DN. The new World Health Organization-European Organization for Research and Treatment of Cancer classification for cutaneous lymphomas: a practical marriage of two giants. Br J Dermatol 2005 Nov;153(5):874-80.

(39) Cerroni L, Zochling N, Putz B, Kerl H. Infection by Borrelia burgdorferi and cutaneous B-cell lymphoma. J Cutan Pathol 1997 Sep; 24(8):457-61.

(40) Pimpinelli N. New aspects in the biology of cutaneous B-cell lymphomas. J Cutan Pathol 2006 Feb;33 Suppl 1:6-9.

(41) May SA, Netto G, Domiati-Saad R, Kasper C. Cutaneous lymphoid hyperplasia and marginal zone B-cell lymphoma following vaccination. J Am Acad Dermatol 2005 Sep;53(3):512-6.

(42) Tsuji K, Suzuki D, Naito Y, Sato Y, Yoshino T, Iwatsuki K. Primary cutaneous marginal zone B-cell lymphoma. Eur J Dermatol 2005 Nov;15(6):480-3.

(43) Colli C, Leinweber B, Mullegger R, Chott A, Kerl H, Cerroni L. Borrelia burgdorferi-associated lymphocytoma cutis: clinicopathologic, immunophenotypic, and molecular study of 106 cases. J Cutan Pathol 2004 Mar;31(3):232-40.

(44) Zenahlik P, Fink-Puches R, Kapp KS, Kerl H, Cerroni L. [Therapy of primary cutaneous B-cell lymphomas]. Hautarzt 2000 Jan;51(1):19-24.

(45) Mori M, Campolmi P, Mavilia L, Rossi R, Cappugi P, Pimpinelli N. Topical photodynamic therapy for primary cutaneous B-cell lymphoma: a pilot study. J Am Acad Dermatol 2006 Mar;54(3):524-6.

(46) Suarez F, Lortholary O, Hermine O, Lecuit M. Infection-associated lymphomas derived from marginal zone B cells: a model of antigendriven lymphoproliferation. Blood 2006 Apr 15;107(8):3034-44.

(47) Prince HM, Yap LM, Blum R, McCormack C. Primary cutaneous B-cell lymphomas. Clin Exp Dermatol 2003 Jan;28(1):8-12.

(48) Grange F, Bekkenk MW, Wechsler J, Meijer CJ, Cerroni L, Bernengo M, et al. Prognostic factors in primary cutaneous large B-cell lymphomas: a European multicenter study. J Clin Oncol 2001 Aug 15;19(16):3602-10.

(49) Cerroni L KHGK. Cutaneous B cell lymphomas. In: Blackwell Science, editor. An Illustrated Guide to Skin Lymphoma. $1^{\text {th }}$ ed. 1998. p. 63-87.

(50) Grange F, Petrella T, Beylot-Barry M, Joly P, D'Incan M, Delaunay M, et al. Bcl-2 protein expression is the strongest independent prognostic factor of survival in primary cutaneous large B-cell lymphomas. Blood 2004 May 15;103(10):3662-8. 
(51) Geelen FA, Vermeer MH, Meijer CJ, Van der Putte SC, Kerkhof E, Kluin $\mathrm{PM}$, et al. bcl-2 protein expression in primary cutaneous large B-cell lymphoma is site-related. J Clin Oncol 1998 Jun;16(6):2080-5.

(52) Roglin J, Boer A. Skin manifestations of intravascular lymphoma mimic inflammatory diseases of the skin. Br J Dermatol 2007 May 15.

(53) Kodama K, Massone C, Chott A, Metze D, Kerl H, Cerroni L. Primary cutaneous large B-cell lymphomas: clinicopathologic features, classification, and prognostic factors in a large series of patients. Blood 2005 Oct 1;106(7):2491-7.

(54) Cerroni L, Kerl H. Diagnostic immunohistology: cutaneous lymphomas and pseudolymphomas. Semin Cutan Med Surg 1999 Mar;18(1):64-70.

(55) LeBoit PE. "Magic bullets" in immunohistochemistry. Am J Dermatopathol 2002 Dec;24(6):518-20.

(56) Hallermann C, Niermann C, Fischer RJ, Schulze HJ. New prognostic relevant factors in primary cutaneous diffuse large B-cell lymphomas. J Am Acad Dermatol 2007 Apr;56(4):588-97.

(57) Jaffe ES. Anaplastic large cell lymphoma: the shifting sands of diagnostic hematopathology. Mod Pathol 2001 Mar;14(3):219-28.

(58) shton-Key M, Diss TC, Isaacson PG, Smith ME. A comparative study of the value of immunohistochemistry and the polymerase chain reaction in the diagnosis of follicular lymphoma. Histopathology 1995 Dec;27(6):501-8.

(59) Soares FA, Arias VEA. Linfomas não Hodgkin de células T. In: Alves VAF, BC, VJ, editors. Manual de imuno-histoquímica.São Paulo: Sociedade Brasileira de Dermatologia; 1999. p. 141-51.

(60) Hallermann C, Kaune KM, Tiemann M, Kunze E, Griesinger F, Mitteldorf $\mathrm{C}$, et al. High frequency of primary cutaneous lymphomas associated with lymphoproliferative disorders of different lineage. Ann Hematol 2007 Mar 6.

(61) Sundram U, Kim Y, Mraz-Gernhard S, Hoppe R, Natkunam Y, Kohler S. Expression of the bcl-6 and MUM1/IRF4 proteins correlate with overall and disease-specific survival in patients with primary cutaneous large Bcell lymphoma: a tissue microarray study. J Cutan Pathol 2005 Mar;32(3):227-34.

(62) Hans CP, Weisenburger DD, Greiner TC, Gascoyne RD, Delabie J, Ott $G$, et al. Confirmation of the molecular classification of diffuse large Bcell lymphoma by immunohistochemistry using a tissue microarray. Blood 2004 Jan 1;103(1):275-82. 
(63) Kazakov DV, Burg G, Kempf W. Primary cutaneous B-cell lymphomas and pseudolymphomas: review of histopathological features. Cesk Patol 2002 Oct;38(4):147-54.

(64) Kerl H. B-cell epidermotropism in lymphomas. Am J Dermatopathol 1999 Feb;21(1):110.

(65) de LL, Harris NL, Longtine J, Ferry JA, Duncan LM. Cutaneous b-cell lymphomas of follicular and marginal zone types: use of Bcl-6, CD10, Bcl-2, and CD21 in differential diagnosis and classification. Am J Surg Pathol 2001 Jun;25(6):732-41.

(66) Leinweber B, Colli C, Chott A, Kerl H, Cerroni L. Differential diagnosis of cutaneous infiltrates of B lymphocytes with follicular growth pattern. Am J Dermatopathol 2004 Feb;26(1):4-13.

(67) Santucci M, Pimpinelli N, Arganini L. Primary cutaneous B-cell lymphoma: a unique type of low-grade lymphoma. Clinicopathologic and immunologic study of 83 cases. Cancer 1991 May 1;67(9):2311-26.

(68) Kazakov DV, Burg G, Dummer R, Kempf W. Cutaneous lymphomas and pseudolymphomas: newly described entities. Recent Results Cancer Res 2002;160:283-93.

(69) Boudova L, Kazakov DV, Sima R, Vanecek T, Torlakovic E, Lamovec J, et al. Cutaneous lymphoid hyperplasia and other lymphoid infiltrates of the breast nipple: a retrospective clinicopathologic study of fifty-six patients. Am J Dermatopathol 2005 Oct;27(5):375-86.

(70) Wood GS. Inflammatory diseases that simulate lymphomas: cutaneous pseudolymphomas. In: Freedberg IM EAWKeal, editor. Fitzpatrick's dermatology in general medicine. $6^{\text {th }}$ ed. ed. New York: McGraw-Hill; 2003. p. $1567-80$.

(71) Caro WA, Helwig HB. Cutaneous lymphoid hyperplasia. Cancer 1969 Sep;24(3):487-502.

(72) Wood GS, Ngan BY, Tung R, Hoffman TE, Abel EA, Hoppe RT, et al. Clonal rearrangements of immunoglobulin genes and progression to $B$ cell lymphoma in cutaneous lymphoid hyperplasia. Am J Pathol 1989 Jul;135(1):13-9.

(73) de Visser KE, Korets LV, Coussens LM. De novo carcinogenesis promoted by chronic inflammation is B lymphocyte dependent. Cancer Cell 2005 May;7(5):411-23.

(74) Gutermuth J, Audring H, Roseeuw D. Disseminated cutaneous B-cell lymphoma mimicking pseudolymphoma over a period of six years. Am J Dermatopathol 2004 Jun;26(3):225-9. 
(75) Brodell RT, Santa Cruz DJ. Cutaneous pseudolymphomas. Dermatol Clin 1985 Oct;3(4):719-34.

(76) Kempf W, Dummer R, Burg G. Approach to lymphoproliferative infiltrates of the skin. The difficult lesions. Am J Clin Pathol 1999 Jan;111(1 Suppl 1):S84-S93.

(77) Rijlaarsdam JU, Meijer CJ, Willemze R. Differentiation between lymphadenosis benigna cutis and primary cutaneous follicular center cell lymphomas. A comparative clinicopathologic study of 57 patients. Cancer 1990 May 15;65(10):2301-6.

(78) Mahalingam M, Sander CA, Holm N. Atypical cutaneous lymphocytic infiltrates - paucicellularity and pseudo'clonality. J Cutan Pathol 2003 Jan 9;30(8):521.

(79) Holm N, Flaig MJ, Yazdi AS, Sander CA. The value of molecular analysis by PCR in the diagnosis of cutaneous lymphocytic infiltrates. J Cutan Pathol 2002 Sep;29(8):447-52.

(80) Magro C, Crowson AN, Porcu P, Nuovo GJ. Automated kappa and lambda light chain mRNA expression for the assessment of B-cell clonality in cutaneous B-cell infiltrates: its utility and diagnostic application. J Cutan Pathol 2003 Sep;30(8):504-11.

(81) Hofbauer GF, Kessler B, Kempf W, Nestle FO, Burg G, Dummer R. Multilesional primary cutaneous diffuse large B-cell lymphoma responsive to antibiotic treatment. Dermatology 2001;203(2):168-70.

(82) Chong WS, Thomas A, Goh CL. Kimura's disease and angiolymphoid hyperplasia with eosinophilia: two disease entities in the same patient: case report and review of the literature. Int J Dermatol 2006 Feb;45(2):139-45.

(83) buel-Haija M, Hurford MT. Kimura disease. Arch Pathol Lab Med 2007 Apr;131(4):650-1.

(84) Moran CA, Suster S. Angiolymphoid hyperplasia with eosinophilia (epithelioid hemangioma) of the lung: a clinicopathologic and immunohistochemical study of two cases. Am J Clin Pathol 2005 May;123(5):762-5.

(85) Roca B. [Lyme borreliosis]. Med Clin (Barc ) 2006 Jul 15;127(7):265-8.

(86) Steere AC. Lyme borreliosis in 2005, 30 years after initial observations in Lyme Connecticut. Wien Klin Wochenschr 2006 Nov; 118(21-22):625-33. 
(87) Diss TC, shton-Key M, Pan LX, Isaacson PG. Clonality analysis of B-cell lymphomas. Hum Pathol 1995 Sep;26(9):1046.

(88) Diss TC, Liu HX, Du MQ, Isaacson PG. Improvements to B cell clonality analysis using PCR amplification of immunoglobulin light chain genes. Mol Pathol 2002 Apr;55(2):98-101.

(89) Paraskevas F, Lee ST, Maghazachi AA. Antisuppression: a novel pathway in $T$ cell regulation of $B$ cell function. Surv Immunol Res 1984;3(2-3):115-21.

(90) Child FJ, Russell-Jones R, Woolford AJ, Calonje E, Photiou A, Orchard $\mathrm{G}$, et al. Absence of the $\mathrm{t}(14 ; 18)$ chromosomal translocation in primary cutaneous B-cell lymphoma. Br J Dermatol 2001 Apr;144(4):735-44.

(91) Dummer R, Willers J, Kamarashev J, Urosevic M, Dobbeling U, Burg G. Pathogenesis of cutaneous lymphomas. Semin Cutan Med Surg 2000 Jun;19(2):78-86.

(92) Hsi ED, Mirza I, Gascoyne RD. Absence of $t(14,18)$ chromosomal translocation in primary cutaneous B-cell lymphoma. Br J Dermatol 2002 Jun;146(6):1110-1.

(93) Hughes J, Weston S, Bennetts B, Prasad M, Angulo R, Jaworskit R, et al. The application of a PCR technique for the detection of immunoglobulin heavy chain gene rearrangements in fresh or paraffinembedded skin tissue. Pathology 2001 May;33(2):222-5.

(94) Nikiforova MN, Hsi ED, Braziel RM, Gulley ML, Leonard DG, Nowak JA, et al. Detection of clonal IGH gene rearrangements: summary of molecular oncology surveys of the College of American Pathologists 4. Arch Pathol Lab Med 2007 Feb;131(2):185-9.

(95) Child FJ, Russell-Jones R, Woolford AJ, Calonje E, Whittaker SJ. Immunoglobulin heavy chain variable region family expression in primary cutaneous B-cell lymphomas. $\mathrm{Br} J$ Dermatol 2001 Oct;145(4):680.

(96) Child FJ, Woolford AJ, Calonje E, Russell-Jones R, Whittaker SJ. Molecular analysis of the immunoglobulin heavy chain gene in the diagnosis of primary cutaneous B cell lymphoma. J Invest Dermatol 2001 Oct;117(4):984-9.

(97) Medeiros LJ, Carr J. Overview of the role of molecular methods in the diagnosis of malignant lymphomas. Arch Pathol Lab Med 1999 Dec;123(12):1189-207. 
(98) Pai RK, Chakerian AE, Binder JM, Amin M, Viswanatha DS. B-cell clonality determination using an immunoglobulin kappa light chain polymerase chain reaction method. J Mol Diagn 2005 May;7(2):300-7.

(99) Korsmeyer SJ, Hieter PA, Ravetch JV, Poplack DG, Waldmann TA, Leder P. Developmental hierarchy of immunoglobulin gene rearrangements in human leukemic pre-B-cells. Proc Natl Acad Sci U S A 1981 Nov;78(11):7096-100.

(100) Diss TC, Pan L, Peng H, Wotherspoon AC, Isaacson PG. Sources of DNA for detecting B cell monoclonality using PCR. J Clin Pathol 1994 Jun;47(6):493-6.

(101) Bagg A, Braziel RM, Arber DA, Bijwaard KE, Chu AY. Immunoglobulin heavy chain gene analysis in lymphomas: a multi-center study demonstrating the heterogeneity of performance of polymerase chain reaction assays. J Mol Diagn 2002 May;4(2):81-9.

(102) Xu D, Du J, Kamino H, Ratech H. Rapid diagnosis of clonal immunoglobulin heavy chain gene rearrangements in cutaneous B-cell lymphomas using the LightCycler-Polymerase Chain Reaction with DNA melting curve analysis. Am J Dermatopathol 2004 Oct; 26(5):385-9.

(103) Gong JZ, Zheng S, Chiarle R, De Wolf-Peeters C, Palestro G, Frizzera $G$, et al. Detection of immunoglobulin kappa light chain rearrangements by polymerase chain reaction. An improved method for detecting clonal B-cell lymphoproliferative disorders. Am J Pathol 1999 Aug; 155(2):355-63.

(104) Nihal M, Mikkola D, Wood GS. Detection of clonally restricted immunoglobulin heavy chain gene rearrangements in normal and lesional skin: analysis of the B cell component of the skin-associated lymphoid tissue and implications for the molecular diagnosis of cutaneous B cell lymphomas. J Mol Diagn 2000 Feb;2(1):5-10.

(105) Amara K, Trimeche M, Ziadi S, Sriha B, Mokni M, Korbi S. PCR-based clonality analysis of B-cell lymphomas in paraffin-embedded tissues: diagnostic value of immunoglobulin kappa and lambda light chain gene rearrangement investigation. Pathol Res Pract 2006;202(6):425-31.

(106) Child FJ, Russell-Jones R, Calonje E, Whittaker SJ. Molecular genetic characterization of primary cutaneous B-cell lymphomas. Am J Surg Pathol 2001 Apr;25(4):538-9.

(107) Child FJ, Scarisbrick JJ, Calonje E, Orchard G, Russell-Jones R, Whittaker SJ. Inactivation of tumor suppressor genes p15(INK4b) and p16(INK4a) in primary cutaneous B cell lymphoma. J Invest Dermatol 2002 Jun;118(6):941-8. 
(108) Streubel B, Scheucher B, Valencak J, Huber D, Petzelbauer P, Trautinger $F$, et al. Molecular cytogenetic evidence of $\mathrm{t}(14 ; 18)(\mathrm{IGH} ; \mathrm{BCL} 2)$ in a substantial proportion of primary cutaneous follicle center lymphomas. Am J Surg Pathol 2006 Apr;30(4):529-36.

(109) Gronbaek K, Moller PH, Nedergaard T, Thomsen K, Baadsgaard O, Hou-Jensen K, et al. Primary cutaneous B-cell lymphoma: a clinical, histological, phenotypic and genotypic study of 21 cases. $\mathrm{Br} J$ Dermatol 2000 May;142(5):913-23.

(110) Zsikla V, Baumann M, Cathomas G. Effect of buffered formalin on amplification of DNA from paraffin wax embedded small biopsies using real-time PCR. J Clin Pathol 2004 Jun;57(6):654-6.

(111) van Dongen JJ, Langerak AW, Bruggemann M, Evans PA, Hummel M, Lavender FL, et al. Design and standardization of PCR primers and protocols for detection of clonal immunoglobulin and T-cell receptor gene recombinations in suspect lymphoproliferations: report of the BIOMED-2 Concerted Action BMH4-CT98-3936. Leukemia 2003 Dec;17(12):2257-317.

(112) Mahalingam M. Atypical cutaneous lymphocytic infiltratespaucicellularity and 'pseudo'clonality. J Cutan Pathol 2003 Sep;30(8):521.

(113) Yazdi AS, Puchta U, Flaig MJ, Sander CA. Laser-capture microdissection: applications in routine molecular dermatopathology. J Cutan Pathol 2004 Aug;31(7):465-70.

(114) Gimenez S, Costa C, Espinet B, Sole F, Pujol RM, Puigdecanet E, et al. Comparative genomic hybridization analysis of cutaneous large Bcell lymphomas. Exp Dermatol 2005 Dec;14(12):883-90.

(115) Mao X, Lillington D, Child F, Russell-Jones R, Young B, Whittaker S. Comparative genomic hybridization analysis of primary cutaneous Bcell lymphomas: identification of common genomic alterations in disease pathogenesis. Genes Chromosomes Cancer 2002 Oct;35(2):144-55.

(116) Wiesner T, Streubel B, Huber D, Kerl H, Chott A, Cerroni L. Genetic aberrations in primary cutaneous large B-cell lymphoma: a fluorescence in situ hybridization study of 25 cases. Am J Surg Pathol 2005 May;29(5):666-73.

(117) Gallardo F, Pujol RM, Bellosillo B, Ferrer D, Garcia M, Barranco C, et al. Primary cutaneous B-cell lymphoma (marginal zone) with prominent T-cell component and aberrant dual ( $T$ and $B$ ) genotype; diagnostic usefulness of laser-capture microdissection. $\mathrm{Br} J$ Dermatol 2006 Jan;154(1):162-6. 